\title{
Product Consistency Testing of Three Reference Glasses in Stainless Steel and Perfluoroalkoxy Resin Vessels
}

K.M. Olson

G.L. Smith

S.C. Marschman

March 1995

Prepared for the U.S. Department of Energy under Contract DE-AC06-76RLO 1830

Pacific Northwest Laboratory Operated for the U.S. Department of Energy by Battelle Memorial Institute 


\title{
DISCLAIMER
}

This report was prepared as an account of work sponsored by an agency of the United States Government. Neither the United States Government nor any agency thereof, nor Battelle Memorial Institute, nor any of their employees, makes any warranty, expressed or implied, or assumes any legal liability or responsibility for the accuracy, completeness, or usefulness of any information, apparatus, product, or process disclosed, or represents that its use would not infringe privately owned rights. Reference herein to any specific commercial product, process, or service by trade name, trademark, manufacturer, or otherwise does not necessarily constitute or imply its endorsement, recommendation, or favoring by the United States Government or any agency thereof, or Battelle Memorial Institute. The views and opinions of authors expressed herein do not necessarily state or reflect those of the United States Government or any agency thereof.

\author{
PACIFIC NORTHWEST LABORATORY \\ operated by \\ BATTELLE MEMORIAL INSTITUTE \\ for the \\ UNITED STATES DEPARTMENT OF ENERGY \\ under Contract DE-ACO6-76RLO 1830
}

Printed in the United States of America

Available to DOE and DOE contractors from the

Office of Scientific and Technical Information, P.O. Box 62, Oak Ridge, TN 37831; prices available from (615) 576-8401. FTS 626-8401.

Available to the public from the National Technical Information Service, U.S. Department of Commerce, 5285 Port Royal Rd., Springfield, VA 22161. 
PNL-10497

UC-510

\title{
Product Consistency Testing of Three Reference Glasses in Stainless Steel and Perfluoroalkoxy Resin Vessels
}

\author{
K.M. Olson \\ G.L. Smith \\ S.C. Marschman
}

March 1995

Prepared for

the U.S. Department of Energy

under Contract DE-AC06-76RLO 1830

Pacific Northwest Laboratory

Richland, Washington 99352 


\section{Summary}

Four different types of vessels and three different glasses were used to study the possible effect of vessel composition on durability test results from the Product Consistency Test (PCT). The vessels were $45-\mathrm{mL}$ 304L stainless steel vessels, $150-\mathrm{mL} 304 \mathrm{~L}$ stainless steel vessels, and 60 -mL perfluoroalkoxy (PFA) fluoropolymer resin vessels. The three glasses were the Environmental Assessment glass manufactured by Corning Incorporated and supplied by Westinghouse Savannah River Company, and West Valley Nuclear Services reference glasses 5 and 6, manufactured and supplied by Catholic University of America. Within experimental error, no differences were found in durability test results using the 3 different glasses in the 304L stainless steel or PFA fluoropolymer resin vessels over the seven-day test period. 


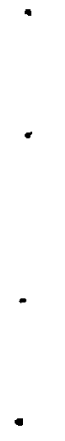




\section{Acknowledgments}

We gratefully acknowledge C. M. Jantzen, N. E. Bibler, M. J. Plodinec, and D. C. Beam of the Savannah River Technology Center for help in gathering data and information, for useful discussions, and for funding this work; I. L. Pegg of the Catholic University of America for supplying the 150-mL stainless steel test vessels and for useful discussions; J. K. Bates of Argonne National Laboratory for useful discussions and for mailing pertinent documents to us; R. E. Westerman of Pacific Northwest Laboratory for helpful discussion of the results; B. P. McGrail of Pacific Northwest Laboratory for technical review; and West Valley Nuclear Services for funding the original tests using these reference glasses in one of the test vessel materials. 


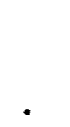




\section{Contents}

Summary $\ldots \ldots \ldots \ldots \ldots \ldots \ldots \ldots \ldots \ldots \ldots \ldots \ldots \ldots \ldots \ldots \ldots$

Acknowledgments $\ldots \ldots \ldots \ldots \ldots \ldots \ldots \ldots \ldots \ldots \ldots \ldots \ldots \ldots \ldots$

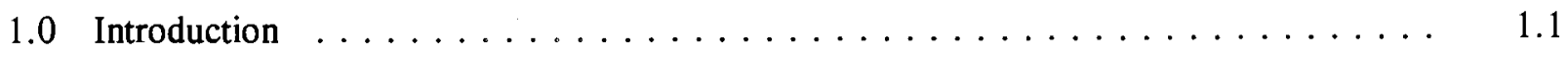

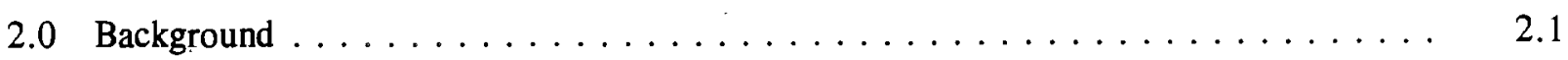

2.1 Corrosion of Borosilicate Glasses $\ldots \ldots \ldots \ldots \ldots \ldots \ldots \ldots \ldots \ldots$

2.2 Glass Corrosion Studies $\ldots \ldots \ldots \ldots \ldots \ldots \ldots \ldots \ldots \ldots \ldots \ldots \ldots$

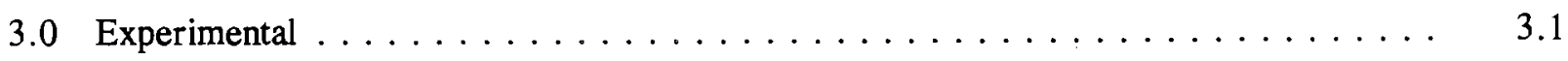

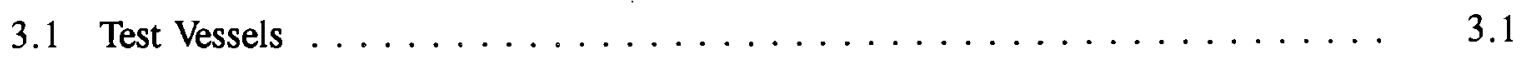

3.2 Glasses $\ldots \ldots \ldots \ldots \ldots \ldots \ldots \ldots \ldots \ldots \ldots \ldots \ldots \ldots \ldots \ldots$

3.3 Durability Testing $\ldots \ldots \ldots \ldots \ldots \ldots \ldots \ldots \ldots \ldots \ldots \ldots$

4.0 Results and Discussion $\ldots \ldots \ldots \ldots \ldots \ldots \ldots \ldots \ldots \ldots \ldots \ldots \ldots$

4.1 Durability Testing $\ldots \ldots \ldots \ldots \ldots \ldots \ldots \ldots \ldots \ldots \ldots \ldots \ldots \ldots$

4.2 Metallography $\ldots \ldots \ldots \ldots \ldots \ldots \ldots \ldots \ldots \ldots \ldots \ldots \ldots \ldots$

4.3 Scanning Electron Microscopy $\ldots \ldots \ldots \ldots \ldots \ldots \ldots \ldots \ldots \ldots \ldots$

5.0 Conclusions and Recommendations $\ldots \ldots \ldots \ldots \ldots \ldots \ldots \ldots \ldots \ldots \ldots \ldots$

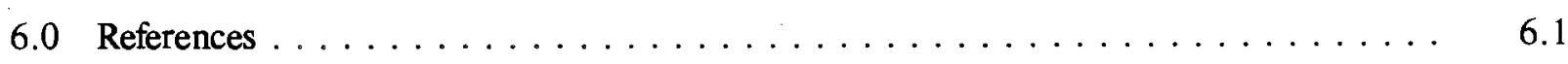




\section{Figures}

3.1 Type P 304L Stainless Steel Vessels Showing Cut-Away View, Order of Assembly, and Fully Assembled Vessel $\ldots \ldots \ldots \ldots \ldots \ldots \ldots$

3.2 Type W 304L Stainless Steel Vessels Showing Cut-Away View, Order of Assembly, and Fully Assembled Vessel

3.3 Type S PFA Fluoropolymer Vessels Showing Cut-Away View, Order of Assembly, and Fully Assembled Vessel . . . . . . . . . . . . . . 3.5

$4.1 \quad$ Release of Boron From EA Glass $\ldots \ldots \ldots \ldots \ldots \ldots \ldots \ldots \ldots$

4.2 Release of Lithium From EA Glass $\ldots \ldots \ldots \ldots \ldots \ldots \ldots$

4.3 Release of Sodium From EA Glass $\ldots \ldots \ldots \ldots \ldots \ldots \ldots \ldots$

4.4 Release of Silicon From EA Glass $\ldots \ldots \ldots \ldots \ldots \ldots \ldots \ldots \ldots$

4.5 Average Leachate $\mathrm{pH}$ After PCTs of EA Glass $\ldots \ldots \ldots \ldots \ldots \ldots$

4.6 Release of Boron From WVNS Reference Glass $5 \ldots \ldots \ldots \ldots \ldots$

4.7 Release of Lithium From WVNS Reference Glass $5 \ldots \ldots \ldots \ldots \ldots$

4.8 Release of Sodium From WVNS Reference Glass $5 \ldots \ldots \ldots \ldots \ldots$

4.9 Release of Silicon From WVNS Reference Glass $5 \ldots \ldots \ldots \ldots$

4.10 Average Leachate $\mathrm{pH}$ After PCTs of WVNS Reference Glass $5 \ldots \ldots \ldots \ldots$

4.11 Release of Boron From WVNS Reference Glass $6 \ldots \ldots \ldots \ldots$

4.12 Release of Lithium From WVNS Reference Glass $6 \ldots \ldots \ldots \ldots \ldots$

4.13 Release of Sodium From WVNS Reference Glass $6 \ldots \ldots \ldots \ldots \ldots$

4.14 Release of Silicon From WVNS Reference Glass $6 \ldots \ldots \ldots \ldots$

4.15 Average Leachate pH After PCTs of WVNS Reference Glass $6 \ldots \ldots \ldots$. . . . . . . 4.11

4.16 Microstructure of Type P Stainless Steel Vessels $\ldots \ldots \ldots \ldots \ldots \ldots$

4.17 Microstructure of Type W Stainless Steel Vessels $\ldots \ldots \ldots \ldots \ldots$. . . . . . . . 4.14 
4.18 Scanning Electron Microscope Examination of New Type $P$

Stainless Steel Vessels .........................

4.19 Scanning Electron Microscope Examination of Used Type P

Stainless Steel Vessels

4.20 Scanning Electron Microscope Examination of New Type W

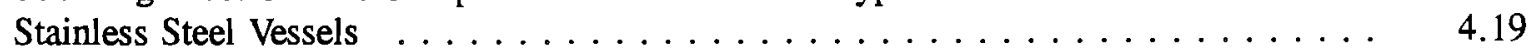

4.21 Scanning Electron Microscope Examination of Used Type W Stainless Steel Vessels 


\section{Tables}

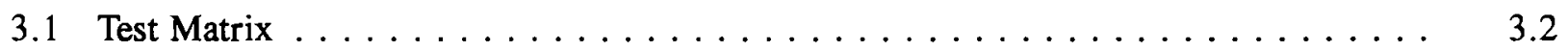

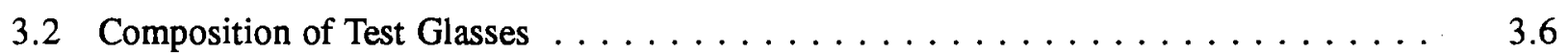

3.3 Test Information and Leachate Analysis for Product Consistency Tests of

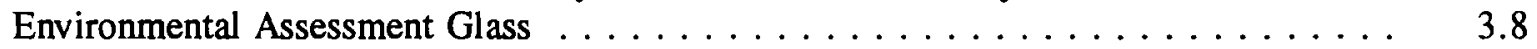

3.4 Test Information and Leachate Analysis for Product Consistency Tests of Reference 5 Glass . . . . . . . . . . . . . . . . . . . . . . . . . . . . . 3.11

3.5 Test Information and Leachate Analysis for Product Consistency Tests of Reference 6 Glass . . . . . . . . . . . . . . . . . . . . . . . . . . . 3.14

3.6 Test Information and Leachate Analysis for Blanks $\ldots \ldots \ldots \ldots \ldots \ldots$

4.1 Average Elemental Leachate Concentrations and $\mathrm{pH}$ Values $\ldots \ldots \ldots \ldots . \ldots \ldots$ 


\subsection{Introduction}

Because of their chemical durability, silicate glasses have been proposed and researched since the mid-1950s as a medium for incorporating high-level radioactive waste (HLW) generated from processing of nuclear materials. A number of different waste forms were evaluated and ranked in the early 1980s; durability (leach resistance) was the highest weighted factor. Borosilicate glass was rated the best waste form available for incorporation of HLW (US DOE 1981). In 1990, the U.S. Environmental Protection Agency (EPA) declared that the vitrification of HLW was the Best Demonstrated Available Technology (BDAT) (40 CRF Part 148, 22700).

The U.S. Department of Energy (DOE) will vitrify HLW using borosilicate glass, and the glass will be poured into canisters. These activities will be carried out at the Savannah River Site, Aiken, South Carolina; the West Valley Demonstration Project, West Valley, New York; and the Hanford Site, Richland, Washington. The likely disposal site will be a geologic repository. Because of the likelihood that borosilicate glass will eventually contact various media that would promote corrosion of the waste glass and release of radionuclides, it is important that we understand glass corrosion behavior. The compositional ranges of borosilicate glasses that may be used to incorporate HLW must demonstrate good resistance to corrosion by aqueous media, which is the most likely path for release of radionuclides to the environment once the canister and other barriers fail.

To be accepted into the Civilian Radioactive Waste Management System (US DOE 1993), vitrified HLW forms must meet DOE's technical Waste Acceptance Product Specifications (WAPS). The WAPS requires that the relative chemical durability of the waste form shall be better than the Defense Waste Processing Facility (DWPF) Environmental Assessment (EA) glass standard reference material (Jantzen et al. 1993), using the Product Consistency Test (PCT) (Jantzen et al. 1992) as the comparative test.

The PCT is a durability test of actual or simulated high-level nuclear waste glass. The test is used to assess the chemical durability of both homogeneous and devitrified glasses by determining the concentrations in leachates of various chemical species that are released from the crushed glass. The concentrations are indicative of the glass corrosion rate.

There are two test methods contained within the PCT, Method A and Method B; these differ only in the flexibility of test conditions. Method A stipulates the use of $304 \mathrm{~L}$ stainless steel test vessels, -100 to +200 -mesh crushed glass, $90^{\circ} \mathrm{C}$ test temperature, 7-day test duration, ASTM-Type I water leachant, and the use of at least $1 \mathrm{~g}$ of crushed glass in an amount of ASTM-Type I water equal to 10 times the sample mass.

Method B is very similar to A but allows for varying the following test conditions: sample particle size, test temperature, test duration, leachant, ratio of glass sample to leachate volume, and test vessel material. The test vessels may be either 304L stainless steel or perfluoroalkoxy (PFA) Teflon ${ }^{\otimes}$. Teflon ${ }^{\circledast}$ vessels cannot be used to test HLW glass because the material is damaged by high radiation doses ( $>1 \times 10^{5}$ rads of beta or gamma radiation), which can contaminate the leachate with fluoride. 
Because PFA Teflon ${ }^{\circledR}$ vessels are 10 to 15 times less expensive than the stainless steel vessels, the bulk of glass corrosion studies to qualify various HLW borosilicate glass compositions has been performed using simulated nuclear waste glasses tested in PFA Teflon vessels. Most researchers have agreed that the vessel material type, either stainless steel or PFA Teflon ${ }^{\otimes}$, probably has not affected the glass corrosion data gathered during 7-day PCT tests. Such data from either vessel could, therefore, be used to presume data for actual radioactive HLW glasses. However, Catholic University of America (CUA, Xing and Pegg 1994) researchers indicated that the concentration of various chemical species in the leachate may differ depending on whether the test vessels are stainless steel or PFA Teflon ${ }^{\otimes}$, even at time periods of 7 days.

Because of this discrepancy, a series of tests were initiated at Pacific Northwest Laboratory $(\mathrm{PNL})^{(\mathrm{a})}$ to investigate whether different test results are derived by performing the PCT in vessels of differing material. The glasses to be tested were reference glasses that had already been used as standard glasses in previous tests for West Valley Nuclear Services (WVNS). The glasses tested were the EA glass and WVNS reference glasses 5 and 6 . The tests were conducted in 150-mL 304L stainless steel test vessels, 45-mL 304L stainless steel test vessels, and 60-mL PFA resin test vessels.

This technical report presents our test results. Chapter 2 provides background information, Chapter 3 describes our experimental approach, and Chapter 4 is a discussion of our results. Tables and figures presenting test data are included at the ends of Chapters 3 and 4 .

(a) Pacific Northwest Laboratory is operated by Battelle Memorial Institute for the U.S. Department of Energy under Contract DE-AC06-76RLO 1830. 


\subsection{Background}

This section includes a brief description of the chemical durability of borosilicate glasses and associated corrosion processes (Section 2.1). For a more complete description of corrosion processes, consult Volumes 1 through 3 US DOE (1994). Section 2.2 contains relevant research pertaining to the effect different test vessel materials may have on experimental data.

\subsection{Corrosion of Borosilicate Glasses}

A combination of diffusion-controlled ion exchange and dissolution-controlled hydrolysis controls corrosion of borosilicate glasses containing alkali elements. Diffusion-controlled ion exchange proceeds by diffusing water into the glass, ion exchange with extraction of alkali ions, and release of alkalis into the leachate. Dissolution-controlled hydrolysis degrades the actual glass network through hydrolysis and dissolution reactions. Diffusion-controlled ion exchange and dissolution-controlled hydrolysis occur in parallel when the glass is initially introduced into water. Diffusion-controlled ion exchange is dominant in the early stages of glass corrosion, and dissolution-controlled hydrolysis dominates in later stages.

Borosilicate glass generally has a slow surface dissolution rate compared to its diffusion rate, but the dissolution rate eventually becomes dominant due to the increasing surface thickness of the diffusion layer with time. The three stages of glass corrosion are 1) diffusion-controlled ion exchange, 2) ion exchange and glass network hydrolysis and dissolution reactions, with dissolution being the ratecontrolling step, and 3) long-term corrosion whose processes are less well defined.

The corrosion rate of waste glass has been shown experimentally to be affected by a number of factors, i.e., solution chemistry, diffusion through surface altered layers, $\mathrm{pH}$ of the leachate solution, glass composition, formation of secondary phases, and interaction with surrounding materials. For most experimental studies, including this report, corrosion of the borosilicate glass network is usually estimated and reported by the cumulative release of $\mathrm{B}$ along with $\mathrm{Li}$ and $\mathrm{Na}$. For a detailed description of corrosion work on borosilicate glasses, refer to "High-Level Waste Borosilicate Glass: A Compendium of Corrosion Characteristics," Volumes 1 through 3 (US DOE 1994).

\subsection{Glass Corrosion Studies}

Xing and Pegg (1994) studied the effects of test vessel material on PCT durability data using simulated HLW glasses. The glasses studied were PUREX, SRL-131, and the DWPF EA glass. PCT results were reported for periods up to 380 days. This study showed different leach rate results for the PUREX glass using 60-mL Savillex PFA Teflon ${ }^{\star}$ and 150-mL 304L Whitey stainless test vessels. Higher leachate concentrations were found when using the stainless steel rather than the Teflon ${ }^{\infty}$ vessels. This difference was seen as early as 7 days, and it increased with increasing time. The difference was attributed to dissolved carbon dioxide in the leachates; Teflon ${ }^{\infty}$ is permeable to atmospheric carbon dioxide while 304L stainless steel is not. An increase in carbon dioxide content could lower the leachate solution $\mathrm{pH}$ by forming carbonic acid, thereby reducing the glass leach rate. This effect is postulated to be strongly dependent on the glass composition, since only the durability results for PCTs of PUREX glass showed this difference. 
Jantzen et al. (1993, 1994) compared the PCT leachate data from tests of the EA glass in three different vessels conducted by four different researchers. The three vessels were $60-\mathrm{mL}, 517 \mathrm{kPa}$ (75-psi) Teflon vessels; 22-mL Parr 304L stainless steel vessels (the Parr vessels had a well polished interior finish); and 150-mL 304L stainless steel cylinders (the steel cylinders did not have a well polished interior finish). ASTM-Type I water was used as the leachant in all cases. The head space in the 22-mL Parr 304L stainless steel vessels varied: 1) 19-mL of ASTM-Type I water with $3 \mathrm{~mL}$ head space of air, and 2) $15-\mathrm{mL}$ of ASTM-Type I water with $7 \mathrm{~mL}$ head space of air. All testing was conducted during a 7-day period. Varying head space in the 22-mL 304L stainless steel Parr vessels affected neither the $\mathrm{pH}$ nor the final leachate concentrations. The interior finishes of the two types of stainless steel vessels, although different, produced comparable PCT results and appeared to introduce little variability, certainly less than "analyst-to-analyst" variability, which was greater than occurred by varying the type of test vessels.

Two other studies, both using Teflon test vessels, may shed light on the issue of $\mathrm{CO}_{2}$ affecting PCT results (Reimus et al. 1988 and Olson et al. 1994). In 1987 and 1988, Reimus et al. conducted a West Valley Compositional Variation Glass study to test $\mathbf{4 4}$ glasses. Reimus et al. used a modified MCC-3 test (precursor to the PCT), a test similar to the PCT, but included a small amount of agitation and excluded $\mathrm{CO}_{2}$ from the test environment. The $\mathrm{CO}_{2}$ was excluded by using deaerated ASTM-Type I water leachant and Ascarite ${ }^{\circledast} \mathrm{CO}_{2}$ sorbent) during the 7-day test period.

In 1992, Olson et al. tested the still-available 44 glasses according to the PCT, which called for neither exclusion of $\mathrm{CO}_{2}$ from the Teflon ${ }^{\oplus}$ test vessels nor agitation. Olson's results were compared to those of Reimus et al. using normalized release rates for $\mathrm{B}$ and $\mathrm{Li}$. The two sets of test results were similar; in the majority of cases, the normalized release rate differences were $\leq 10 \%$. Although $\mathrm{CO}_{2}$ values were not measured in the resulting leachates for either study, one would expect the tests that used Ascarite would have had lower levels of $\mathrm{CO}_{2}$ in the leachates as opposed to the tests for which special precautions were not taken to exclude $\mathrm{CO}_{2}$. In addition, the measured $\mathrm{pH}$ values for both studies were within experimental error, and the agitation used in the MCC-3 testing did not appear to affect the leachate concentration results.

Seven glasses from the Defense Waste Processing Facility (DWPF) reference Waste Compliance Plan (WCP), (WSRC 1988) were tested using the PCT. ${ }^{\text {(a) }}$ The seven glasses were: Blend 1, Batches 1 through 4, HM, and PUREX. The glasses were tested by three analysts using two different vessel types, Teflon ${ }^{\otimes}$ and Parr steel. In addition, PUREX glass was tested in Teflon ${ }^{\infty}$, in Parr steel, as well as in a steel cylinder by a fourth analyst to eliminate analyst-to-analyst variability. The vessels used in this study were 1) $60-\mathrm{mL}, 517 \mathrm{kPa}$ (75-psi) Teflon vessels; 2) 22-mL 304L stainless steel Parr bombs (Parr bomb had a well polished interior finish); and 3) $150-\mathrm{mL} 304 \mathrm{~L}$ stainless steel cylinders with Swagelok ${ }^{\circledast}$ fittings (Georgia Valve and Fitting Co.) (interior of steel cylinder was unpolished).

(a) Personal communication with C.M. Jantzen, to be published as: Jantzen, C.M., N.E. Bibler, D.C. Beam, C.L. Crawford, S.L. Marra, A.A. Ramsey, and M.A. Pickett. In preparation. Development and Characterization of the Defense Waste Processing Facility (DWPF) Waste Compliance Plan (WCP) Glasses. WSRC-TR-93-181, Westinghouse Savannah River Company, Aiken, South Carolina. 
Test results from three different analysts using the Teflon ${ }^{\oplus}$ and Parr steel vessels for all seven glasses showed there were no significant statistical differences caused by analyst-to-analyst or vessel material variability. However, the PUREX glass exhibited the largest variance of the seven glasses for all measured elements. A fourth analyst tested the PUREX glass, using six samples and performing three triplicate analyses in the Teflon ${ }^{\otimes}$, Parr steel, and steel cylinders. This test generated six sets of triplicate leachate analysis results. This study found that the type of vessel material used had no significant impact on the PUREX glass leachate analyses.

A draft report from Jantzen et al. ${ }^{(a)}$ discusses using the THERMO model to study glass dissolution interactions and the effects of atmospheric $\mathrm{CO}_{2}$ and carbonate species in solution. They evaluated the dissolution in the framework of weak acids (WA) and strong bases (SB) and found that the carbonic acid equilibria with atmospheric $\mathrm{CO}_{2}$ contribute little to changes in $\mathrm{pH}$ for values greater than 8 . Though this work substantiates the above findings, it is in contrast with the findings of Xing and Pegg (CUA).

To date, very few glass corrosion studies have been performed to determine the effects of test vessel materials. The results of this study will be added to the existing database.

(a) Personal communication with C.M. Jantzen, to be published as: Jantzen C.M., J.B. Pickett and D.C. Beam. In preparation. Process/Product Models for the Defense Waste Processing Facility (DWPF): Part I. Predicting Glass Durability from Composition Using a Thermodynamic Hydration Energy Reaction MOdel (THERMO) (U). WSRC-TR-93-672, Westinghouse Savannah River Company, Aiken, South Carolina. 



\subsection{Experimental}

The test matrix for these experiments is shown in Table 3.1. During summer 1993, the PCT was used to test three glasses (EA glass and WVNS references glasses 5 and 6) in four types of test vessels. All conditions of the testing were as stipulated under Method A, except for using the types of test vessels allowed in Method B. The PCT is a 7-day durability test of crushed glass in ASTM-Type I water (deionized water or DIW) at $90^{\circ} \mathrm{C}$. Table 3.1 presents the test matrix, including vessel material and glass; the procedure is discussed in more detail below.

\subsection{Test Vessels}

The four different vessel types are shown in Figures 3.1 to 3.3. Figure 3.1 actually shows two types of $45-\mathrm{mL} 304 \mathrm{~L}$ stainless steel vessels, since type $\mathrm{P}$ and type $\mathrm{R}$ vessels look identical. However, they are listed separately because they were produced by different manufacturers. Initial tests compared type $P$ and type $R$ vessels and, when no difference was found, these vessels were used interchangeably and are identified as mixed $R$ and $P$ vessels. The only difference between the vessels was cost.

Figure 3.2 shows a type W $150-\mathrm{mL} 304 \mathrm{~L}$ stainless steel vessel. These vessels were originally made for sampling and transporting samples between field storage sites and laboratory facilities. The inside surface is considerably rougher than the smoothly machined surface of type $R$ or type $P$ vessels.

The third type of vessel was the 60-mL PFA fluoropolymer resin vessel; this vessel is shown in Figure 3.3 and is identified in this report as type $S$. Cleaned, previously used type $S$ vessels were used because new vessels were unavailable when these tests began.

The first tests listed for types $\mathrm{R}, \mathrm{P}$, and $\mathrm{W}$ vessels were performed in new vessels; later tests were performed in the same (now used) vessels. Both new and used vessels were cleaned before use, as outlined in the PCT procedure (Jantzen et al. 1992). The cleaning process involved degreasing the test vessels, if new, followed by rinses in fresh DIW, a soak in $0.16 \mathrm{M} \mathrm{HNO} \mathrm{HN}_{3}$ at $90^{\circ} \mathrm{C}$, and a number of rinses in fresh DIW. For the final cleaning step, the vessel was filled with DIW and placed in a $90^{\circ} \mathrm{C}$ oven for $24 \mathrm{~h}$. The $\mathrm{pH}$ and Si levels of the resulting DIW leachate were measured. The Si level in the DIW cleaning blank is a good indicator of the thoroughness of cleaning. None of the cleaning blanks showed any $\mathrm{Si}$, with one exception, noted below in Table 3.60. The pH level of the DIW cleaning blank in all cases was in the correct range of 5.0 to 7.0 . 
Table 3.1. Test Matrix

\begin{tabular}{|c|c|c|c|c|c|}
\hline & $\begin{array}{l}\text { Test } \\
\text { Glass }\end{array}$ & $\begin{array}{c}\text { Vessel } \\
\text { Material }\end{array}$ & $\begin{array}{c}\text { Manifacturer } \\
\text { ID }\end{array}$ & $\begin{array}{c}\text { Number } \\
\text { of Tests (a) }\end{array}$ & $\begin{array}{c}\text { Date } \\
\text { of Tests }\end{array}$ \\
\hline & EA Glass & 304L SS & $\mathbf{R}$ & 6 & Jun $18,22,1993$ \\
\hline & EA Glass & 304 L SS & $\mathbf{P}$ & 2 & Jun $18,22,1993$ \\
\hline & EA Glass & $304 \mathrm{~L}$ SS & Mixed R \& P & 6 & Jul 15,16, 1993 \\
\hline & EA Glass & 304L SS & W & 3 & Jul 27, Aug 11, Sep 22, 1993 (b) \\
\hline & EA Glass & PFA & S & 3 & Jul 16,1994 \\
\hline & WWNS Ref. Glass 5 & $304 \mathrm{~L} S S$ & $\mathbf{R}$ & 6 & Jun $18,22,1993$ \\
\hline & WVNS Ref. Glass 5 & $304 L$ SS & $\mathbf{P}$ & 3 & Jun $18,22,1993$ \\
\hline$\cdot$ & WWNS Ref. Glass 5 & 304L SS & Mixed R \& P & 5 & Jul 15,16, 1993 \\
\hline & WNNS Ref. Glass 5 & 304L SS & W & 4 & Jul 27, Aug 11, Sep 2, Sep 22, 1993 (b) \\
\hline & WVNS Ref. Glass 5 & PFA & $\mathbf{S}$ & 3 & Jul 16, 1994 \\
\hline i & WNNS Ref. Glass 6 & $304 L$ SS & R & 1 & Jun $18,22,1993$ \\
\hline & WVNS Ref. Glass 6 & $304 \mathrm{~L} \mathrm{SS}$ & $\mathbf{P}$ & 3 & Jun $18,22,1993$ \\
\hline & WVNS Ref. Glass 6 & 304L SS & Mixed R \& P & 2 & Jul $15,16,1993$ \\
\hline & WVNS Ref. Glass 6 & $304 \mathrm{~L}$ SS & W & 3 & Jul 27, Aug 11, Sep 22, 1993 (b) \\
\hline & WNSS Ref. Glass 6 & PFA & $s$ & 3 & Jul 16, 1994 \\
\hline & Blank (None) & $304 \mathrm{~L}$ SS & $R$ & 2 & Jun $18,22,1993$ \\
\hline & Blank (None) & 304L SS & $P$ & 2 & Jun $18,22,1993$ \\
\hline & Blank (None) & 304L SS & Mixed $R$ \& P & 4 & Jul 15,16, 1993 \\
\hline & Blank (None) & $304 \mathrm{~L}$ SS & w & $12(c)$ & (Cleaning Blanks) \\
\hline & Blank (None) & PFA & $\mathrm{S}$ & 2 & Jul 16, 1994 \\
\hline
\end{tabular}

(a) Does not include tests that lost more than $10 \%$ of leachant.

(b) One test was begun on each date for a minimum of three tests.

(c) No blanks were run with the tests. With three vessels, all were used for glass tests. Data listed as "blank" data for W vessels are actually from cleaning blanks. 


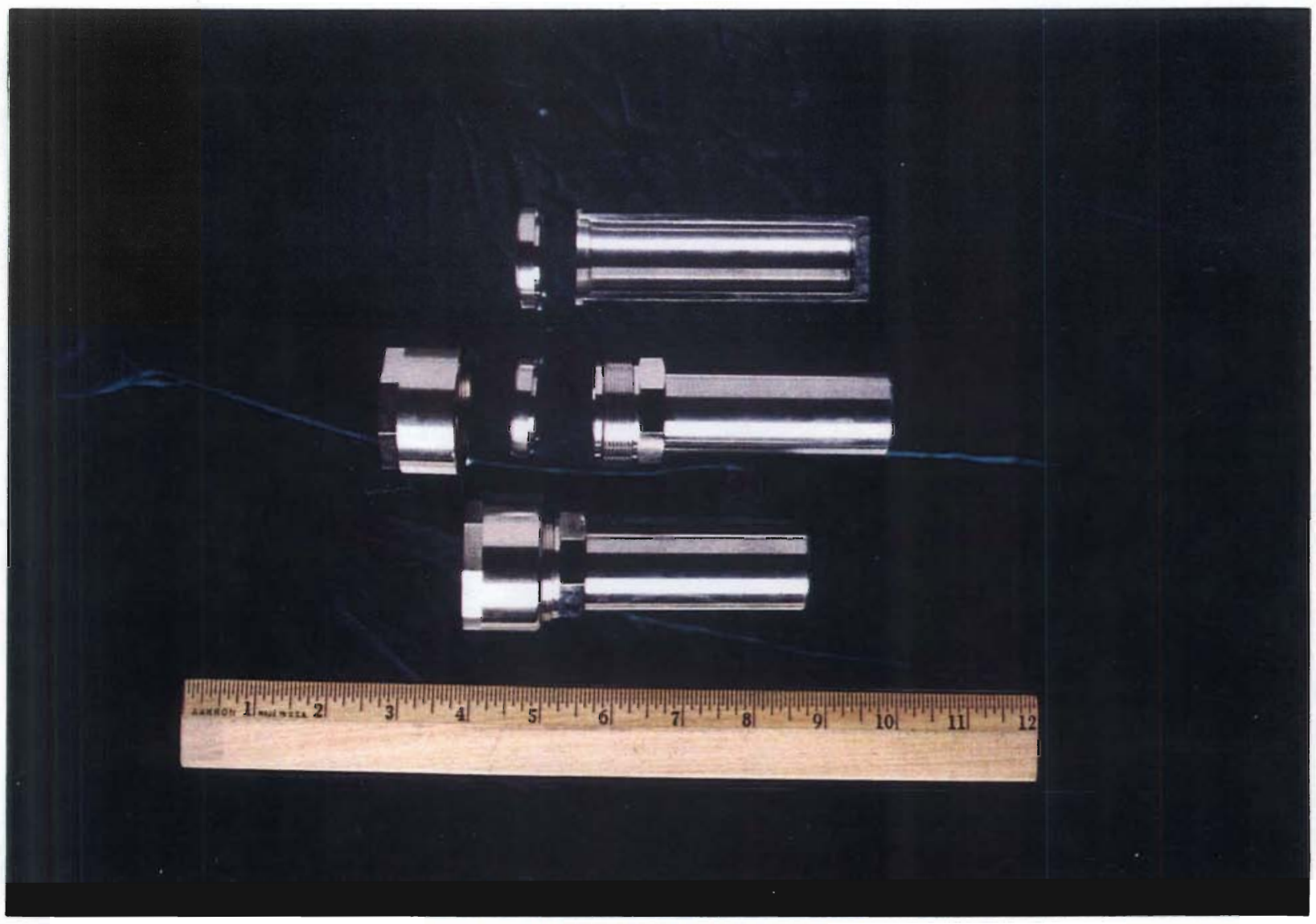

Figure 3.1. Type P 304L Stainless Steel Vessels Showing Cut-Away View (top), Order of Assembly (middle), and Fully Assembled Vessel (bottom). This photo also represents type R vessels which are identical to type P vessels. $(1 \mathrm{in} .=2.54 \mathrm{~cm})$

The type $S$ vessels had been cleaned using PNL's standard cleaning procedure. ${ }^{\text {(a) }}$ PNL's standard cleaning procedures began with a soak in a $6 \underline{\mathrm{M}} \mathrm{HNO}_{3}$ and $0.2 \underline{\mathrm{M}} \mathrm{HF}$ solution. This soak was followed by a 4-h soak in a $50^{\circ} \mathrm{C}, 6 \underline{\mathrm{M}}$ solution of $\mathrm{HNO}_{3}$. Nine rinses followed, each in fresh DIW. The first 3 rinses were immersions, the second 3 rinses involved soaking in hot DIW, and the final 3 rinses were also immersions.

(a) Olson, K. M. April 1993. "MCC-TP-19: Leaching Tests Using the PCT Method, Rev. 1." PNL Technical Procedure, Pacific Northwest Laboratory, Richland, Washington. 


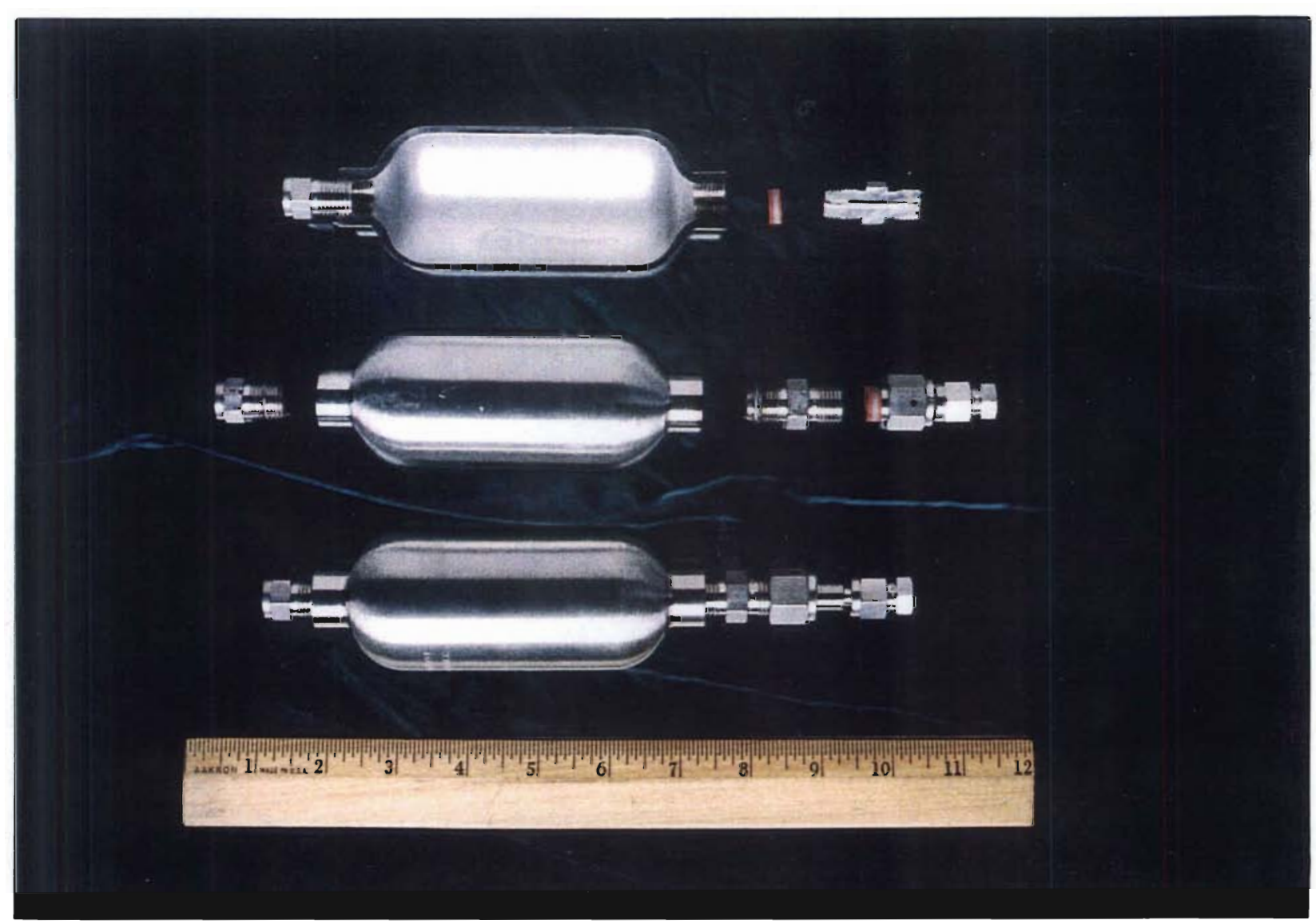

Figure 3.2. Type W 304L Stainless Steel Vessels Showing Cut-Away View (top), Order of Assembly (middle), and Fully Assembled Vessel (bottom). Cut-away view shows rough inner surface.

\subsection{Glasses}

The tested glasses were the EA glass and WVNS reference glasses 5 and 6 . The EA glass was manufactured by Corning Incorporated for WSRC, and the glass was supplied by WSRC. The WVNS reference glasses were manufactured and supplied by CUA, and contain $U$ and Th. The compositions of these three glasses are listed in Table 3.2.

\subsection{Durability Testing}

Durability testing (leaching) was performed according to MCC-TP-19, Rev.. 1, which is based on Version 5.0 of the PCT. The PCT is a 7-day test of crushed glass in DIW leachant (Jantzen et al. 1992). 


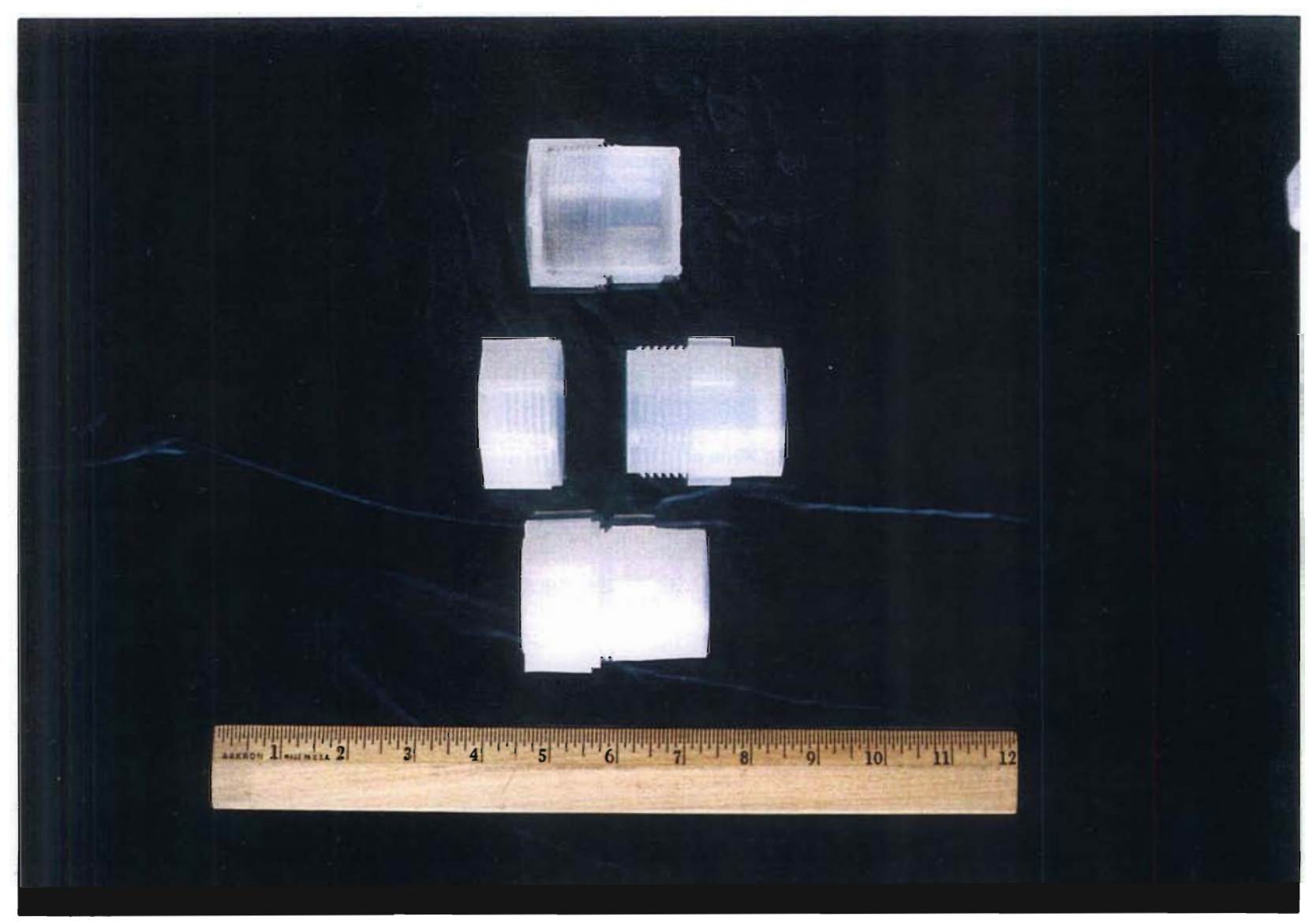

Figure 3.3. Type S PFA Fluoropolymer Vessels Showing Cut-Away View (top), Order of Assembly (middle), and Fully Assembled Vessel (bottom)

WVNS Reference glass 5 was the only glass in bar form, which required breaking; the bars were placed in a plastic bag and broken with a hammer. Thereafter, all the glasses were handled in the same way. The glass pieces were placed in a Frischer mechanical mortar and pestle for grinding. The mortar and pestle are made of ceramic; no metal contacted the glass during crushing. The glass particles were sized using 100 - and 200-mesh sieves. The crushed material was produced by alternating crushing and sieving. After the glass was crushed, approximately half the sample was in the correct size range of -100 to +200 mesh.

At the beginning of crushing, approximately $25 \mathrm{mkg}$ of glass was placed in the crusher; this resulted in about $12 \mathrm{mkg}$ of sample in the correct size range. Additional glass was added to the crusher since more than $12 \mathrm{mkg}$ was required. Crushing was always continued until less than $0.5 \mathrm{mkg}$ of glass remained to be crushed; at that point, the small amount of remaining glass was discarded. 
Table 3.2. Composition of Test Glasses

\begin{tabular}{|c|c|c|c|c|c|c|}
\hline \multirow[b]{2}{*}{$\begin{array}{c}\text { Oxide } \\
\text { Component }\end{array}$} & \multicolumn{2}{|c|}{ EA Glass $^{(a)}$} & \multicolumn{2}{|c|}{$\begin{array}{l}\text { WVNS Reference } 5 \\
\text { (CUA WVCM 62) }\end{array}$} & \multicolumn{2}{|c|}{$\begin{array}{c}\text { WVNS Reference } 6 \\
\text { (CUA WVCM 70) }\end{array}$} \\
\hline & $\begin{array}{c}\text { Corning } \\
\text { Analysis } \\
\text { (Wt\%) }\end{array}$ & $\begin{array}{l}\text { WSRL } \\
\text { Analysis } \\
\text { (Wt \%) }\end{array}$ & $\begin{array}{c}\text { CUA } \\
\text { Composition }^{(b)} \\
\text { (Wt } \%)\end{array}$ & $\begin{array}{c}\text { PNL } \\
\text { Analysis }^{(c)} \\
(\mathrm{Wt} \%)\end{array}$ & $\begin{array}{c}\text { CUA } \\
\text { Composition }^{(b)} \\
\text { (Wt } \%)\end{array}$ & $\begin{array}{c}\text { Corning } \\
\text { Analysis }^{(d)} \\
(W t \%)\end{array}$ \\
\hline $\mathrm{Al}_{2} \mathrm{O}_{3}$ & 3.70 & 3.60 & 6.45 & 6.67 & 6.00 & 6.02 \\
\hline $\mathrm{B}_{2} \mathrm{O}_{3}$ & 11.28 & 11.16 & 12.89 & 10.87 & 12.89 & 12.80 \\
\hline $\mathrm{BaO}$ & & & 0.16 & 0.11 & 0.16 & 0.14 \\
\hline $\mathrm{CaO}$ & 1.12 & 1.23 & 0.68 & 0.94 & 0.48 & 0.57 \\
\hline $\mathrm{CeO}_{2}$ & & & 0.16 & 0.10 & 0.16 & 0.17 \\
\hline $\mathrm{CoO}$ & & & 0.02 & 0.02 & 0.02 & 0.02 \\
\hline $\mathrm{Cr}_{2} \mathrm{O}_{3}$ & & & 0.14 & 0.27 & 0.14 & 0.17 \\
\hline $\mathrm{Cs}_{2} \mathrm{O}$ & & & 0.08 & N.A. ${ }^{(e)}$ & 0.08 & 0.08 \\
\hline $\mathrm{CuO}$ & & & 0.03 & 0.02 & 0.03 & 0.06 \\
\hline $\mathrm{Fe}_{2} \mathrm{O}_{3}$ & 7.38 & 7.58 & 12.02 & 11.88 & 12.02 & 11.90 \\
\hline $\mathrm{FeO}$ & 1.45 & 1.59 & & & & \\
\hline $\mathrm{K}_{2} \mathrm{O}$ & 0.04 & 0.04 & 3.18 & 3.07 & 5.00 & 5.13 \\
\hline $\mathrm{La}_{2} \mathrm{O}_{3}$ & 0.42 & 0.28 & 0.04 & 0.04 & 0.04 & 0.05 \\
\hline $\mathrm{Li}_{2} \mathrm{O}$ & 4.26 & 4.21 & 2.71 & 3.07 & 3.71 & 3.68 \\
\hline $\mathrm{Mg}_{\mathrm{g}} \mathrm{O}$ & 1.72 & 1.79 & 0.89 & 1.02 & 0.89 & 0.92 \\
\hline MnO & 1.34 & 1.36 & 1.01 & 0.91 & 1.01 & 1.09 \\
\hline $\mathrm{MoO}_{3}$ & & & 0.04 & 0.05 & 0.04 & 0.04 \\
\hline $\mathrm{Na}_{2} \mathrm{O}$ & 16.81 & 16.88 & 9.82 & 9.83 & 8.00 & 8.12 \\
\hline $\mathrm{Nd}_{2} \mathrm{O}_{3}$ & & & 0.14 & 0.10 & 0.14 & 0.13 \\
\hline $\mathrm{NiO}$ & 0.57 & 0.53 & 0.25 & 0.30 & 0.25 & 0.26 \\
\hline $\mathrm{P}_{2} \mathrm{O}_{5}$ & & & 2.37 & 2.25 & 1.20 & 1.18 \\
\hline $\mathrm{PdO}$ & & & 0.03 & & 0.03 & 0.03 \\
\hline $\mathrm{Pr}_{6} \mathrm{O}_{11}$ & & & 0.04 & N.A. ${ }^{(e)}$ & 0.04 & 0.06 \\
\hline $\mathrm{RhO}_{2}$ & & & 0.02 & & 0.02 & 0.02 \\
\hline $\mathrm{RuO}_{2}$ & & & 0.08 & 0.03 & 0.08 & 0.03 \\
\hline $\mathrm{SO}_{3}$ & & & 0.23 & N.A. ${ }^{(e)}$ & 0.23 & 0.26 \\
\hline $\mathrm{SiO}_{2}$ & 48.73 & 48.76 & 41.16 & 43.02 & 40.98 & 40.90 \\
\hline $\mathrm{Sm}_{2} \mathrm{O}_{3}$ & & & 0.03 & N.A. ${ }^{(e)}$ & 0.03 & 0.06 \\
\hline $\mathrm{SrO}^{2}$ & & & 0.02 & 0.02 & 0.02 & 0.02 \\
\hline $\mathrm{ThO}_{2}$ & & & 3.56 & 3.48 & 3.56 & 3.36 \\
\hline $\mathrm{TiO}_{2}$ & 0.70 & 0.65 & 0.80 & 0.82 & 0.80 & 0.80 \\
\hline $\mathrm{UO}_{2}$ & & & 0.59 & 0.66 & 0.59 & 0.56 \\
\hline $\mathrm{Y}_{2} \mathrm{O}_{3}$ & & & 0.02 & 0.02 & 0.02 & 0.04 \\
\hline $\mathrm{ZnO}$ & & 0.26 & 0.02 & 0.03 & 0.02 & 0.03 \\
\hline $\mathrm{ZrO}_{2}$ & 0.46 & 0.48 & 0.32 & 0.31 & 1.32 & -1.30 \\
\hline Total & 99.98 & 100.40 & 100.00 & 100.00 & 100.00 & 100.00 \\
\hline
\end{tabular}

(a) C. M. Jantzen, N. E. Bibler, D. C. Beam, C. L. Crawford and M. A. Pickett. June 1, 1993. Characterization of the Defense Whste Processing Facility (DWPF) Environmental Assessment (EA) Glass Standard Reference Material (U), WSRC-TR-92-346.

(b) Composition provided by CUA.

(c) Based on a triplicate analysis at PNL.

(d) Analysis provided by Corning Laboratory Services (CELS), based on 6 analyses.

(e) N.A. means not analyzed. 
The glass in the correct size range was washed 7 times. In the first and second washes, up to $20 \mathrm{mkg}$ of glass was placed in a $50-\mathrm{mL}$ beaker. The glass was agitated by forcible squirting with approximately $30 \mathrm{~mL}$ of DIW. After settling for approximately $15 \mathrm{~s}$, the material separated into solid material and dirty supernate, and the supernate was decanted. The third and fourth washes were identical to the first two washes, except that the beaker containing the crushed glass and DIW water was placed in an ultrasonic cleaner for $120 \mathrm{~s}$ before the supernate was decanted. The fifth, sixth, and seventh washes were identical to the third and fourth, except that ethanol was used instead of water. When washing was completed, the glass was dried overnight at $90^{\circ} \mathrm{C}$.

When using types $\mathbf{R}$ or $\mathbf{P}$ stainless steel vessels, the tests were assembled by first taring the weight of the body of each vessel. An amount of glass between approximately 2.50 and $3.25 \mathrm{mkg}$ was placed in each vessel. Although greater accuracy in weighing the sample is required by the PCT procedure, no such balance was then available in this radiation zone. DIW was then added to each vessel; the weight of the DIW leachate was 10 times the weight of each specimen. A lid was placed on each vessel, and each vessel was sealed with two threaded closure pieces by using a wrench and socket designed to fit the threaded pieces (sold by the manufacturer of the type $\mathrm{P}$ vessels).

When using type W stainless steel vessels, each specimen was weighed before it was placed into the vessel; the specimen was inserted into the vessel by passing it through a small funnel. The correct amount of DIW was added, also using the small funnel. The test vessel was then assembled according to manufacturer directions, using Teflon ${ }^{\infty}$ tape in the threads and standard appropriately sized wrenches.

Since static was a problem with the samples when using type S (PFA) vessels, exactly $10 \mathrm{mkg}$ (identical to $10.00 \mathrm{~mL}$ ) DIW was first placed in each vessel. Approximately 2.5 to $3.25 \mathrm{mkg}$ of specimen was added to the DIW in each vessel and enough additional DIW to equal a total of 10 times the specimen weight. The threaded vessels and lids were sealed by using a PFA wrench set (sold by the manufacturer of the type $S$ vessels).

The tests vessels were placed in an oven set at $90^{\circ} \mathrm{C} \pm 1{ }^{\circ} \mathrm{C}$ for 7 days $\pm 4 \mathrm{~h}$. After the tests were completed, the vessels were allowed to cool, and a small aliquot was used to measure $\mathrm{pH}$. The rest of the leachate was filtered and placed in two polyethylene vials-one for inductively coupled plasmaatomic energy spectroscopy (ICP-AES) analysis and another for storage. Both quantities were acidified to $1 \% \mathrm{HNO}_{3}$. The $\mathrm{pH}$ values, leaching results, and other test information are presented in Tables 3.3 through 3.6. The ICP-AES analyses were performed for each element listed in those tables. The ICP-AES analyses were not conducted for Th or U, which were present in both WVNS reference glasses.

Excess leachant $(>5 \%)$ was lost from three test vessels, as indicated in Tables $3.3,3.4$, and 3.5; no data are given for these tests. In addition, one test vessel, as indicated in Table 3.3, was inadvertently left out of the oven.

The cleaning blank that showed the presence of Si was the one used for test CUA-Ref 6-2. The amount of $\mathrm{Si}$ found in the cleaning blank, $2.5 \mathrm{mg} / \mathrm{L}$, must be subtracted from the amount of $\mathrm{Si}$ found in that leachate. 
Table 3.3. Test Information and Leachate Analysis for Product Consistency Tests of Environmental Assessment Glass

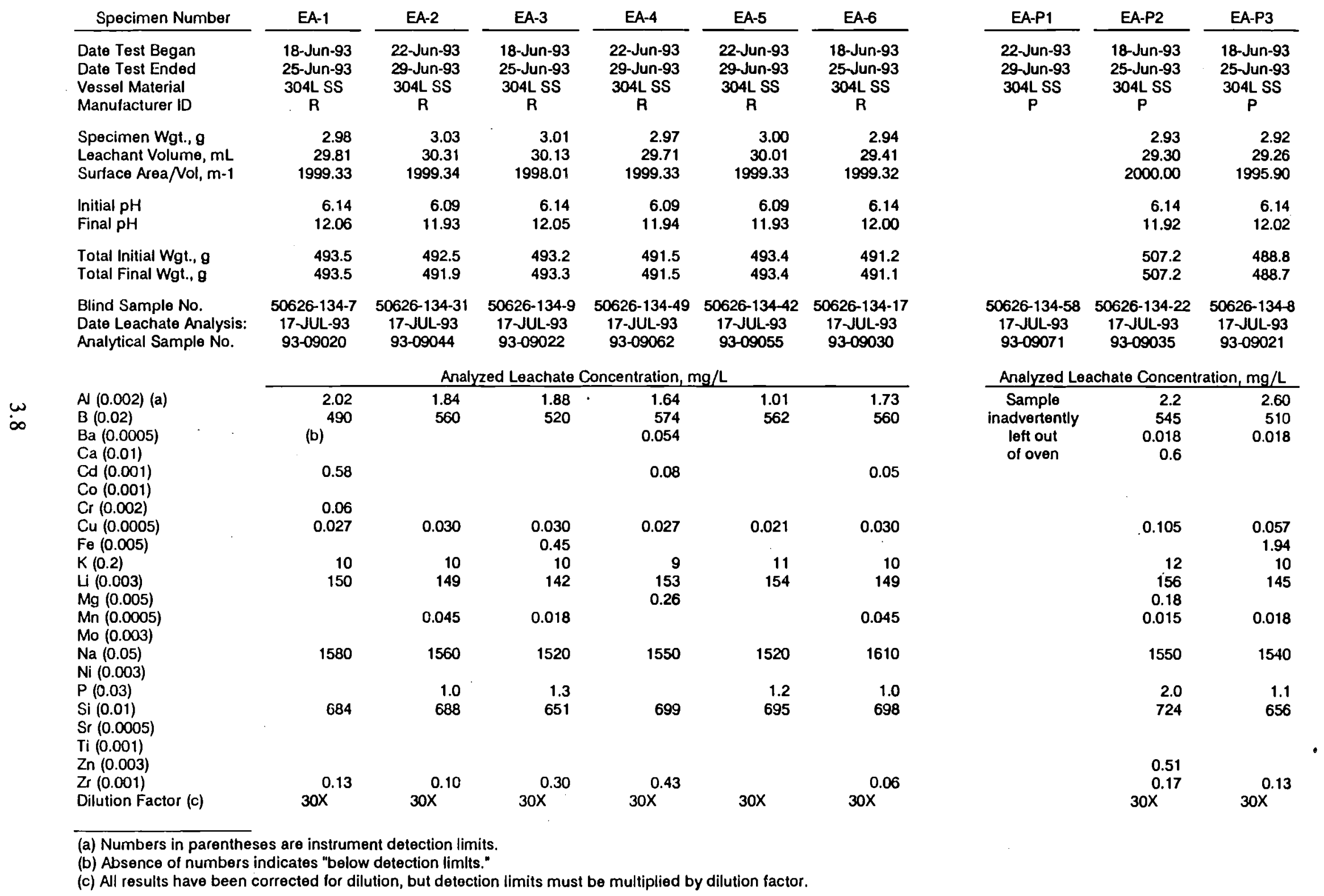


Table 3.3. (contd)

\begin{tabular}{|c|c|c|c|c|c|c|}
\hline Specimen Number & EA-7 & EA-8 & EA-9 & EA-10 & EA.11 & EA-12 \\
\hline $\begin{array}{l}\text { Date Test Began } \\
\text { Date Test Ended } \\
\text { Vessel Material } \\
\text { Manufacturer ID }\end{array}$ & $\begin{array}{c}\text { 16-Jul-93 } \\
23-J u l-93 \\
\text { 304L SS } \\
\text { Mixed R \&P }\end{array}$ & $\begin{array}{l}\text { 15-Jul-93 } \\
22-J u l-93 \\
304 L \text { SS } \\
\text { Mixed R \& P }\end{array}$ & $\begin{array}{c}\text { 16-Jul-93 } \\
23-J u l-93 \\
\text { 304L SS } \\
\text { Mixed A \& P }\end{array}$ & $\begin{array}{c}\text { 15-Jul-93 } \\
\text { 22-Jul-93 } \\
\text { 304L SS } \\
\text { Mixed A \& P }\end{array}$ & $\begin{array}{l}\text { 16-Jul-93 } \\
23-J u l-93 \\
304 L \text { SS } \\
\text { Mixed P \& P }\end{array}$ & $\begin{array}{c}\text { 15-Jul-93 } \\
22-J u l-93 \\
\text { 304L SS } \\
\text { Mixed B \& P }\end{array}$ \\
\hline $\begin{array}{l}\text { Specimen Wgt., g } \\
\text { Leachant Volume, } \mathrm{mL} \\
\text { Surface Area/Nol, m-1 }\end{array}$ & $\begin{array}{r}3.18 \\
31.89 \\
1994.36\end{array}$ & $\begin{array}{r}3.08 \\
30.85 \\
1996.76\end{array}$ & $\begin{array}{r}3.42 \\
34.21 \\
1999.42\end{array}$ & $\begin{array}{r}2.98 \\
29.90 \\
1993.31\end{array}$ & $\begin{array}{r}4.04 \\
40.40 \\
2000.00\end{array}$ & $\begin{array}{r}2.95 \\
29.54 \\
1997.29\end{array}$ \\
\hline $\begin{array}{l}\text { Initial pH } \\
\text { Final pH }\end{array}$ & $\begin{array}{r}5.88 \\
11.91\end{array}$ & $\begin{array}{r}6.02 \\
11.91\end{array}$ & $\begin{array}{r}5.88 \\
11.96\end{array}$ & $\begin{array}{r}6.02 \\
11.89\end{array}$ & $\begin{array}{r}5.88 \\
11.95\end{array}$ & $\begin{array}{r}6.02 \\
11.89\end{array}$ \\
\hline $\begin{array}{l}\text { Total Initial Wgt., g } \\
\text { Total Final Wgt., g }\end{array}$ & $\begin{array}{l}301.54 \\
301.51\end{array}$ & $\begin{array}{l}491.1 \\
491.1\end{array}$ & $\begin{array}{l}306.92 \\
306.91\end{array}$ & $\begin{array}{l}495.5 \\
494.8\end{array}$ & $\begin{array}{l}310.98 \\
310.75\end{array}$ & $\begin{array}{l}508.8 \\
507.8\end{array}$ \\
\hline \multirow[t]{2}{*}{$\begin{array}{l}\text { Blind Sample No. } \\
\text { Date Leachate Analysis } \\
\text { Analytical Sample No. }\end{array}$} & $\begin{array}{c}50626-135-38 \\
27-J u l-93 \\
93-09523\end{array}$ & $\begin{array}{c}50626-135-17 \\
27-J u l-93 \\
93-09502\end{array}$ & $\begin{array}{c}50626-135-33 \\
27-J u l-93 \\
93-09518\end{array}$ & $\begin{array}{l}50626-135-3 \\
27-J u l-93 \\
93-09488\end{array}$ & $\begin{array}{c}50626-135-48 \\
27-J u l-93 \\
93-09533\end{array}$ & $\begin{array}{l}50626-135-13 \\
27-J u l-93 \\
93-09498\end{array}$ \\
\hline & \multicolumn{6}{|c|}{ Analyzed Leachate Concentration, $\mathrm{mg} / \mathrm{L}$} \\
\hline $\begin{array}{l}\text { Al }(0.002)(a) \\
\text { B }(0.02) \\
\text { Ba }(0.0005) \\
\text { Ca }(0.01) \\
\text { Cd }(0.001) \\
\text { Co }(0.001) \\
\text { Cr }(0.002)\end{array}$ & $\begin{array}{r}2.53 \\
571 \\
0.028 \\
\text { (b) } \\
0.036\end{array}$ & $\begin{array}{r}2.73 \\
536 \\
0.033 \\
\\
0.06\end{array}$ & $\begin{array}{l}1.30 \\
585\end{array}$ & $\begin{array}{l}1.40 \\
578\end{array}$ & $\begin{array}{l}0.05 \\
0.03\end{array}$ & $\begin{array}{r}2.25 \\
555 \\
0.0270\end{array}$ \\
\hline $\begin{array}{l}\mathrm{Cu}(0.0005) \\
\mathrm{Fe}(0.005)\end{array}$ & 0.051 & 0.042 & 0.015 & 0.027 & 0.045 & 0.024 \\
\hline $\begin{array}{l}K(0.2) \\
L i(0.003) \\
\operatorname{Mg}(0.005) \\
\operatorname{Mn}(0.0005) \\
\operatorname{Mo}(0.003)\end{array}$ & $\begin{array}{r}11 \\
159\end{array}$ & $\begin{array}{r}11 \\
132 \\
0.40\end{array}$ & $\begin{array}{r}13 \\
137\end{array}$ & $\begin{array}{r}10 \\
146\end{array}$ & $\begin{array}{r}36 \\
112\end{array}$ & $\begin{array}{r}9.0 \\
141 \\
0.22\end{array}$ \\
\hline $\begin{array}{l}\mathrm{Na}(0.05) \\
\mathrm{Ni}(0.003)\end{array}$ & 1510 & 1480 & 1600 & $\begin{array}{r}1580 \\
0.52\end{array}$ & 1360 & 1560 \\
\hline$P(0.03)$ & 1.7 & & & 1.0 & 1.0 & \\
\hline $\begin{array}{l}\text { Si }(0.01) \\
\text { Sr }(0.0005) \\
\text { Ti }(0.001)\end{array}$ & 721 & $\begin{array}{r}613 \\
0.015\end{array}$ & 648 & 687 & 496 & 632 \\
\hline $\begin{array}{l}\operatorname{Zn}(0.003) \\
\operatorname{Zr}(0.001) \\
\text { Dilution Factor (c) }\end{array}$ & $30 \times \quad x^{1.22}$ & $30 \times \quad 0.37$ & $30 \times \begin{array}{l}0.19 \\
0.09\end{array}$ & $30 x^{0.07}$ & $30 \times \begin{array}{l}0.12 \\
0.03\end{array}$ & $30 x^{0.38}$ \\
\hline
\end{tabular}


Table 3.3. (contd)

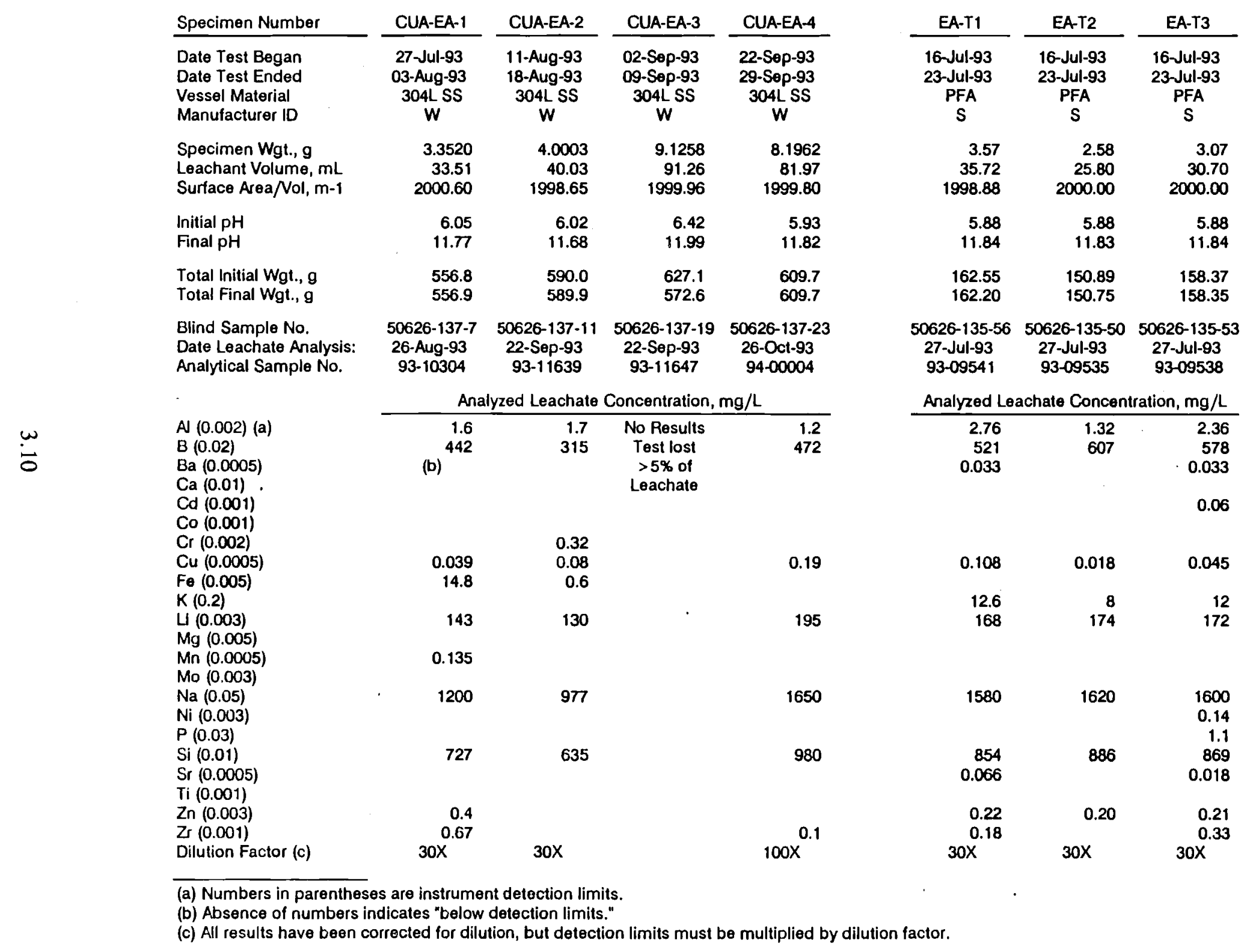


Table 3.4. Test Information and Leachate Analysis for Product Consistency Tests of Reference 5 Glass

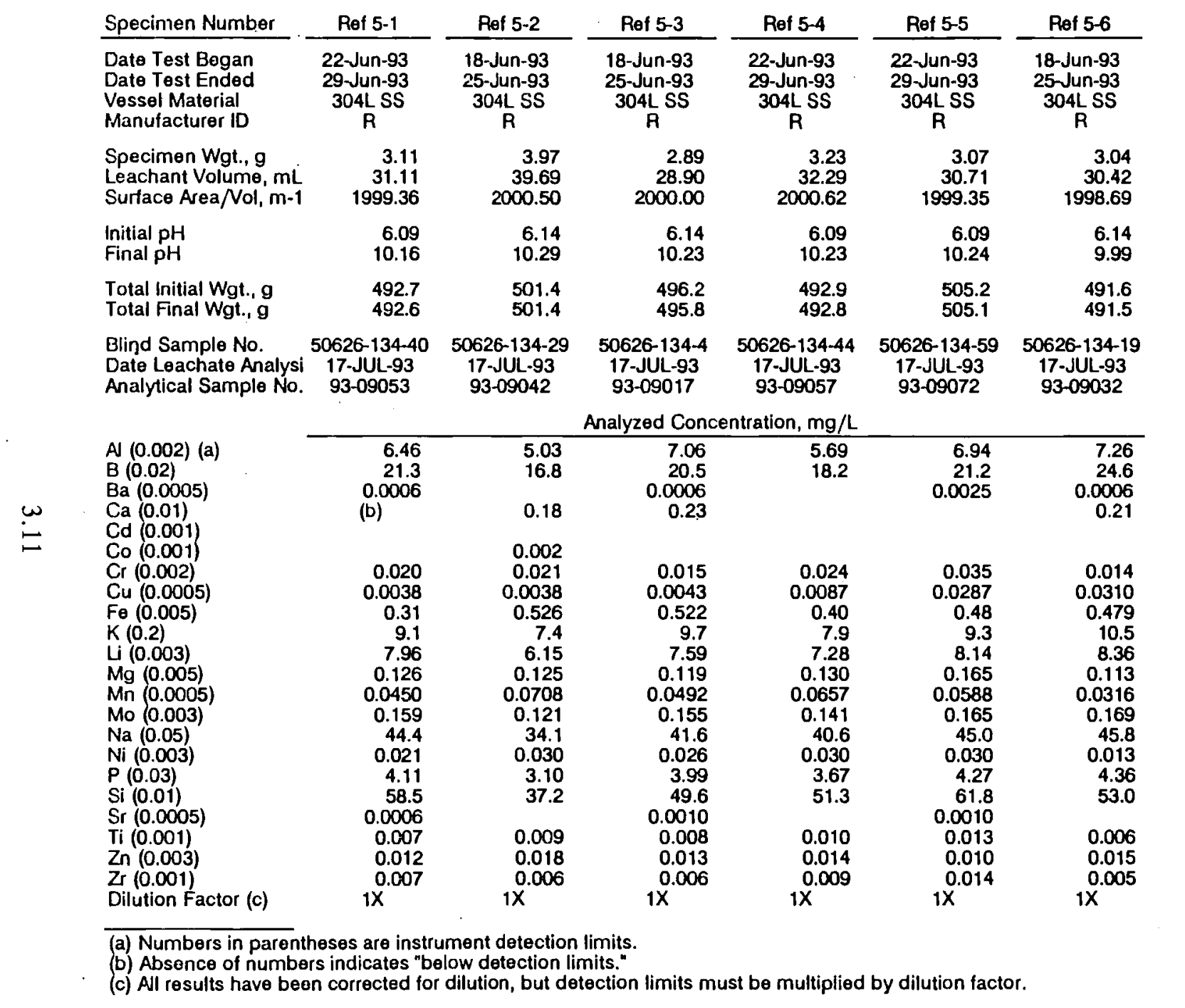

\begin{tabular}{|c|c|c|}
\hline Ref 5-P1 & Ref 5-P2 & Ref 5-P3 \\
\hline $\begin{array}{c}\text { 22-Jun-93 } \\
\text { 29-Jun-93 } \\
304 L \text { SS } \\
\text { P }\end{array}$ & $\begin{array}{c}\text { 18-Jun-93 } \\
25-J u n-93 \\
\text { 304L SS } \\
P\end{array}$ & $\begin{array}{c}22-J u n-93 \\
29-J u n-93 \\
\text { 304L SS } \\
\text { P }\end{array}$ \\
\hline $\begin{array}{r}3.28 \\
32.80 \\
2000.00\end{array}$ & $\begin{array}{r}2.92 \\
29.23 \\
1997.95\end{array}$ & $\begin{array}{r}3.37 \\
33.73 \\
1998.22\end{array}$ \\
\hline $\begin{array}{r}6.09 \\
10.24\end{array}$ & $\begin{array}{r}6.14 \\
10.21\end{array}$ & $\begin{array}{r}6.09 \\
10.21\end{array}$ \\
\hline $\begin{array}{l}514.6 \\
514.6\end{array}$ & $\begin{array}{l}508.5 \\
508.4\end{array}$ & $\begin{array}{l}510.3 \\
510.2\end{array}$ \\
\hline $\begin{array}{c}\text { 50626-134-57 } \\
17-J U L-93 \\
93-09070\end{array}$ & $\begin{array}{c}50626-134-30 \\
17-J U L-93 \\
93-09043\end{array}$ & $\begin{array}{c}50626-134-52 \\
17-J U L-93 \\
93-09065\end{array}$ \\
\hline
\end{tabular}

\begin{tabular}{ccc}
\multicolumn{3}{c}{ Aralyzed Leachate Concentration, $\mathrm{mg} / \mathrm{L}$} \\
\hline 5.05 & 6.77 & 6.61 \\
17.6 & 20.1 & 20.9 \\
0.0006 & 0.20 &
\end{tabular}


Table 3.4. (contd)

\begin{tabular}{|c|c|c|c|c|c|c|}
\hline Specimen Number & Ref 5-7 & Ref 5-8 & Ref 5-9 & Ref 5-10 & Ref 5-11 & Ref 5-12 \\
\hline $\begin{array}{l}\text { Date Test Began } \\
\text { Date Test Ended } \\
\text { Vessel Material } \\
\text { Manufacturer ID }\end{array}$ & $\begin{array}{c}\text { 16-Jul-93 } \\
23-J u l-93 \\
\text { 304L SS } \\
\text { Mixed R \& P }\end{array}$ & $\begin{array}{c}\text { 15-Jul-93 } \\
22-J u l-93 \\
304 L \text { SS } \\
\text { Mixed R \& P }\end{array}$ & $\begin{array}{c}\text { 16-Jul-93 } \\
23-J u l-93 \\
\text { 304L SS } \\
\text { Mixed R \& P }\end{array}$ & $\begin{array}{c}\text { 16-Jul-93 } \\
23 \text { Jul-93 } \\
\text { 304L SS } \\
\text { Mixed R \& P }\end{array}$ & $\begin{array}{c}\text { 15-Jul-93 } \\
22-J u l-93 \\
\text { 304L SS } \\
\text { Mixed P \& P }\end{array}$ & $\begin{array}{c}\text { 15-Jul-93 } \\
22-J u l-93 \\
\text { 304L SS } \\
\text { Mixed R \& P }\end{array}$ \\
\hline $\begin{array}{l}\text { Specimen Wgt., g } \\
\text { Leachant Volume, mL } \\
\text { Surface Area/Nol, m-1 }\end{array}$ & $\begin{array}{r}3.12 \\
31.21 \\
1999.36\end{array}$ & $\begin{array}{r}3.36 \\
33.62 \\
1998.81\end{array}$ & $\begin{array}{r}2.92 \\
29.21 \\
1999.32\end{array}$ & $\begin{array}{r}2.90 \\
29.01 \\
1999.31\end{array}$ & $\begin{array}{r}2.95 \\
29.50 \\
2000.00\end{array}$ & $\begin{array}{r}2.92 \\
29.32 \\
1991.81\end{array}$ \\
\hline $\begin{array}{l}\text { Initial pH } \\
\text { Final pH }\end{array}$ & $\begin{array}{l}5.88 \\
9.93\end{array}$ & $\begin{array}{r}6.02 \\
10.21\end{array}$ & $\begin{array}{r}5.88 \\
10.16\end{array}$ & $\begin{array}{r}5.88 \\
10.22\end{array}$ & $\begin{array}{r}6.02 \\
10.16\end{array}$ & $\begin{array}{r}6.02 \\
10.10\end{array}$ \\
\hline $\begin{array}{l}\text { Total Initial Wgt., g } \\
\text { Total Final Wgt., g }\end{array}$ & $\begin{array}{l}302.51 \\
294.51\end{array}$ & $\begin{array}{l}495.5 \\
494.7\end{array}$ & $\begin{array}{l}297.13 \\
297.08\end{array}$ & $\begin{array}{l}299.48 \\
299.49\end{array}$ & $\begin{array}{l}491.4 \\
491.4\end{array}$ & $\begin{array}{l}491.3 \\
491.3\end{array}$ \\
\hline \multirow[t]{2}{*}{$\begin{array}{l}\text { Blind Sample No. } \\
\text { Date Leachate Analysis } \\
\text { Analytical Sample No. }\end{array}$} & $\begin{array}{l}50626-135-30 \\
27-J u l-93 \\
93-09515\end{array}$ & $\begin{array}{l}50626-135-19 \\
27-J u \mid-93 \\
93-09504\end{array}$ & $\begin{array}{l}50626-135-36 \\
27-J u l-93 \\
93-09521\end{array}$ & $\begin{array}{l}50626-135-35 \\
27-J u l-93 \\
93-09520\end{array}$ & $\begin{array}{l}50626-135-2 \\
27-\text { Jul-93 } \\
93-09487\end{array}$ & $\begin{array}{l}\text { 50626-135-22 } \\
27-J u l-93 \\
93-09507\end{array}$ \\
\hline & \multicolumn{6}{|c|}{ Analyzed Leachate Composition, $\mathrm{mg} / \mathrm{L}$} \\
\hline $\begin{array}{l}\text { A }(0.002)(a) \\
\text { B }(0.02) \\
\text { Ba }(0.0005) \\
\text { Ca }(0.01) \\
\text { Cd }(0.001) \\
\text { Co }(0.001)\end{array}$ & $\begin{array}{l}\text { No Results } \\
\text { Test lost } \\
>5 \% \text { of } \\
\text { Leachate }\end{array}$ & $\begin{array}{r}5.36 \\
19.6 \\
\text { (b) }\end{array}$ & $\begin{array}{r}7.00 \\
19.3 \\
0.0005\end{array}$ & $\begin{array}{l}7.65 \\
21.8\end{array}$ & $\begin{array}{r}6.1 \\
17.7\end{array}$ & $\begin{array}{l}5.40 \\
19.8\end{array}$ \\
\hline $\begin{array}{l}\mathrm{Cr}(0.002) \\
\mathrm{Cu}(0.0005)\end{array}$ & & $\begin{array}{r}0.024 \\
0.0011\end{array}$ & $\begin{array}{r}0.025 \\
0.0039\end{array}$ & $\begin{array}{r}0.027 \\
0.0023\end{array}$ & $\begin{array}{l}0.013 \\
0.001\end{array}$ & $\begin{array}{r}0.025 \\
0.0013\end{array}$ \\
\hline $\begin{array}{l}\mathrm{Fe}(0.005) \\
\mathrm{K}(0.2)\end{array}$ & & $\begin{array}{r}0.314 \\
7.9\end{array}$ & $\begin{array}{r}0.468 \\
9.6\end{array}$ & $\begin{array}{r}0.558 \\
10.4\end{array}$ & $\begin{array}{r}0.303 \\
9\end{array}$ & $\begin{array}{r}0.311 \\
7\end{array}$ \\
\hline U & & 6.19 & 7.38 & 8.23 & 6.57 & 6.02 \\
\hline $\begin{array}{l}\mathrm{Mg}(0.005) \\
\mathrm{Mn}(0.0005)\end{array}$ & & $\begin{array}{r}0.054 \\
0.0252\end{array}$ & $\begin{array}{r}0.090 \\
0.0355\end{array}$ & $\begin{array}{r}0.126 \\
0.0373\end{array}$ & $\begin{array}{r}0.061 \\
0.0275\end{array}$ & $\begin{array}{r}0.054 \\
0.0242\end{array}$ \\
\hline Mo $(0.003)$ & & 0.143 & 0.153 & 0.169 & 0.140 & $\begin{array}{r}0.138 \\
0.138\end{array}$ \\
\hline $\mathrm{Na}(0.05)$ & & 35.7 & 40.5 & 44.4 & 37.5 & 34.5 \\
\hline $\mathrm{Ni}(0.003)$ & & 0.014 & 0.021 & 0.016 & 0.014 & 0.014 \\
\hline$P(0.03)$ & & 3.54 & 3.94 & 4.3 & 3.63 & 3.44 \\
\hline $\begin{array}{l}\text { Si }(0.01) \\
\text { Si }(0.0005)\end{array}$ & & 42.5 & 49.5 & 54.4 & 45.3 & 42.0 \\
\hline $\begin{array}{l}\text { Ti }(0.001) \\
Z n(0.003)\end{array}$ & & 0.007 & 0.008 & 0.007 & $\begin{array}{l}0.006 \\
0.005\end{array}$ & 0.007 \\
\hline $\operatorname{Zr}(0.001)$ & & 0.009 & 0.008 & 0.007 & 0.007 & 0.008 \\
\hline Dilution Factor (c) & & $1 \mathrm{X}$ & $1 X$ & $1 X$ & $1 x$ & 1X. \\
\hline
\end{tabular}

(a) Numbers in parentheses are instrument detection limits.

(b) Absence of numbers indicates "below detection limits."

(c) All results have been corrected for dilution, but detection limits must be multiplied by dilution factor. 
Table 3.4. (contd)

\section{Specimen Number}

\section{Date Test Began}

Date Test Ended

Vessel Material

Manufacturer ID

Specimen Wgt., $g$

Leachant Volume, $m$

Surface Area/Nol, m-1

Initial $\mathrm{pH}$

Final $\mathrm{pH}$

Total Initial Wgt., $g$

Total Final Wgt., g

Blind Sample No.

Date Leachate Analysis:

Analytical Sample No.

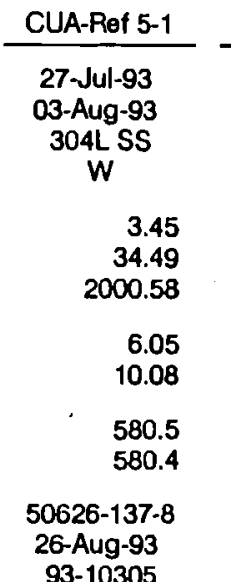

CUA-Ref 5-2 CUA-Ref 5-3

11-Aug-93 18-Aug-93 304L SS

$W$

3.509
33.51

33.51
2094.30

\subsection{2}

6.02
10.07

560.4

560.4

50626-137-12

22-Sep-93

93-11640

Analyzed Leachale

Al $(0.002)(\mathrm{a})$

$\mathrm{B}(0.02)$

$\dot{\omega}_{\omega}^{\omega}$

\begin{tabular}{|c|c|c|c|}
\hline \multicolumn{4}{|c|}{ Analyzed Leachate Concentration, $\mathrm{mg} / \mathrm{L}$} \\
\hline (b) $\begin{array}{r}7.5 \\
16.6\end{array}$ & $\begin{array}{r}7.75 \\
31 \\
0.023\end{array}$ & $\begin{array}{r}7.96 \\
19 \\
0.008\end{array}$ & $\begin{array}{r}7.8 \\
14.4 \\
0.01\end{array}$ \\
\hline
\end{tabular}

02-Sep-93

09-Sep-93

$304 L S S$
$W$

CUA-Rof 5-4

22-Sep-93

304L SS

W

$\begin{array}{rr}5.91 & 4.04 \\ 59.07 & 40.4\end{array}$

59.07
2001.02

6.42

10.13

584.6

584.5

50626-137-17

22-Sep-93

$93-11645$

\begin{tabular}{|c|c|c|}
\hline Ref 5-T1 & Ref 5-T2 & Ref 5-T3 \\
\hline $\begin{array}{c}\text { 16-Jul-93 } \\
\text { 23-Jul-93 } \\
\text { PFA } \\
\text { S }\end{array}$ & $\begin{array}{c}\text { 16-Jul-93 } \\
\text { 23-Jul-93 } \\
\text { PFA } \\
\text { S }\end{array}$ & $\begin{array}{c}\text { 16-Jul-93 } \\
\text { 23-Jul-93 } \\
\text { PFA } \\
\text { S }\end{array}$ \\
\hline $\begin{array}{r}2.83 \\
28.34 \\
1997.18\end{array}$ & $\begin{array}{r}2.93 \\
29.30 \\
2000.00\end{array}$ & $\begin{array}{r}3.06 \\
30.70 \\
1993.49\end{array}$ \\
\hline $\begin{array}{r}5.88 \\
10.17\end{array}$ & $\begin{array}{r}5.88 \\
10.16\end{array}$ & $\begin{array}{r}5.88 \\
10.17\end{array}$ \\
\hline $\begin{array}{l}139.42 \\
138.62\end{array}$ & $\begin{array}{l}154.81 \\
154.66\end{array}$ & $\begin{array}{l}156.99 \\
156.89\end{array}$ \\
\hline $\begin{array}{c}50626-135-57 \\
27-J u l-93 \\
93-09542\end{array}$ & $\begin{array}{c}50626-135-60 \\
27-J u l-93 \\
93-09545\end{array}$ & $\begin{array}{c}\text { 50626-135-54 } \\
27-J u l-93 \\
93-09539\end{array}$ \\
\hline
\end{tabular}

Analyzed Leachate Concentration, $\mathrm{mg} / \mathrm{L}$

\begin{tabular}{rrr} 
Analyzed Leachate Concentration, $\mathrm{mg} / \mathrm{L}$ \\
\hline 7.47 & 7.35 & 7.35 \\
19.9 & 19.5 & 20.4 \\
0.0025 & 0.0016 & 0.0012
\end{tabular}

Cd $(0.001)$

Cd $(0.001)$

Cr (0.002)

$\mathrm{Cu}(0.0005)$

$\mathrm{Fe}(0.005)$

$\mathrm{K}(0.2)$

L $(0.003)$

$\mathrm{Mn}(0.0005)$

Mo (0.003)

$\mathrm{Na}(0.05)$

$\mathrm{Ni}(0.003)$

$P(0.03)$

Si (0.01)

Sr $(0.0005)$

Ti $(0.001)$

Zn $(0.003)$

$\operatorname{Zr}(0.001)$

Dilution Factor (c)

$\begin{array}{rr} & \\ 0.015 & 0.04 \\ 5.4 & 0.03 \\ 9 & 1.25 \\ 7.5 & 16 \\ 0.11 & 15 \\ 0.11 & 0.18 \\ 0.16 & 0.12 \\ 41 & 0.14 \\ & 46 \\ 3.8 & 0.05 \\ 51.2 & 2.3 \\ & 52 \\ & 0.03 \\ 0.22 & 0.04 \\ 1 \times & 1 \times\end{array}$

0.04
0.016
0.92
11
8.39
0.12
0.061
0.19
48
0.03
4.8
56
0.02
0.02
0.01

0.008

0.97
11

8.73

0.1
0.085

0.085

0.18

45
0.02

4.5
64.7

64.7
0.001

$1 \mathrm{X}$

1X

$1 x$

0.023

(a) Numbers in parentheses are instrument detection limits.
(b) Absence of numbers indicates "below detection limits."

(c) All results have been corrected for dilution, but detection limits must be multiplied by dilution factor.

$\begin{array}{rrr}0.014 & 0.016 & 0.016 \\ 0.0006 & 0.0007 & \\ 0.638 & 0.584 & 0.486 \\ 9.7 & 9.6 & 9.6 \\ 7.51 & 7.66 & 7.54 \\ 0.116 & 0.126 & 0.096 \\ 0.0497 & 0.0431 & 0.036 \\ 0.159 & 0.158 & 0.156 \\ 41.1 & 41.2 & 40.5 \\ 0.012 & 0.009 & 0.007 \\ 4.08 & 4.09 & 4.02 \\ 53.1 & 52.1 & 51.9 \\ 0.014 & 0.010 & 0.009 \\ 0.012 & 0.007 & 0.007 \\ 1 X & 1 X & 1 \times\end{array}$


Table 3.5. Test Information and Leachate Analysis for Product Consistency Tests of Reference 6 Glass

\begin{tabular}{|c|c|c|c|c|c|c|c|}
\hline & Specimen Number & Ref 6-1 & Ref 6-P1 & Ref 6-P2 & Ref 6-P3 & REF 6-2 & REF 6-3 \\
\hline & $\begin{array}{l}\text { Date Test Began } \\
\text { Date Test Ended } \\
\text { Vessel Material } \\
\text { Manufacturer ID }\end{array}$ & $\begin{array}{c}\text { 22-Jun-93 } \\
29-J u n-93 \\
304 L \text { SS } \\
\text { R }\end{array}$ & $\begin{array}{c}22-J u n-93 \\
29-J u n-93 \\
304 \text { L SS } \\
P\end{array}$ & $\begin{array}{c}22-J u n-93 \\
29-J u n-93 \\
304 L \text { SS } \\
\text { P }\end{array}$ & $\begin{array}{c}22-J u n-93 \\
29-J u n-93 \\
304 L \text { SS } \\
P\end{array}$ & $\begin{array}{c}\text { 15-Jul-93 } \\
\text { 22-Jul-93 } \\
\text { 304L SS } \\
P\end{array}$ & $\begin{array}{c}\text { 15-Jul-93 } \\
22-J u l-93 \\
\text { 304L SS } \\
\text { Mixed R \& P }\end{array}$ \\
\hline & $\begin{array}{l}\text { Specimen Wgt., g } \\
\text { Leachant Volume, } \mathrm{mL} \\
\text { Surface Area Nol, } \mathrm{m}-1\end{array}$ & $\begin{array}{r}3.02 \\
30.22 \\
1998.68\end{array}$ & $\begin{array}{r}2.87 \\
28.71 \\
1999.30\end{array}$ & $\begin{array}{r}2.89 \\
28.89 \\
2000.69\end{array}$ & $\begin{array}{r}3.02 \\
30.20 \\
2000.00\end{array}$ & $\begin{array}{r}2.88 \\
28.80 \\
2000.00\end{array}$ & $\begin{array}{r}2.95 \\
29.55 \\
1996.62\end{array}$ \\
\hline & $\begin{array}{l}\text { Initial pH } \\
\text { Final pH }\end{array}$ & $\begin{array}{r}6.09 \\
10.09\end{array}$ & $\begin{array}{r}6.09 \\
10.18\end{array}$ & $\begin{array}{r}6.09 \\
10.21\end{array}$ & $\begin{array}{r}6.09 \\
10.15\end{array}$ & $\begin{array}{r}6.02 \\
10.21\end{array}$ & $\begin{array}{r}6.02 \\
10.23\end{array}$ \\
\hline & $\begin{array}{l}\text { Total Initial Wgt., g } \\
\text { Total Final Wgt., } g\end{array}$ & $\begin{array}{l}493.4 \\
493.4\end{array}$ & $\begin{array}{l}511.0 \\
510.9\end{array}$ & $\begin{array}{l}493.5 \\
493.5\end{array}$ & $\begin{array}{l}493.2 \\
493.3\end{array}$ & $\begin{array}{l}505.2 \\
505.3\end{array}$ & $\begin{array}{l}491.3 \\
490.6\end{array}$ \\
\hline & $\begin{array}{l}\text { Blind Sample No. } \\
\text { Date Leachate Analysis: } \\
\text { Analytical Sample No. }\end{array}$ & $\begin{array}{l}50626-134-46 \\
17-J U L-93 \\
93-09059\end{array}$ & $\begin{array}{l}50626-134-55 \\
17-J U L-93 \\
93-09068\end{array}$ & $\begin{array}{l}50626-134-37 \\
17-J U L-93 \\
93-09050\end{array}$ & $\begin{array}{l}50626-134-39 \\
17-J U L-93 \\
93-09052\end{array}$ & $\begin{array}{l}\text { 50626-135-25 } \\
27 \text { Jul-93 } \\
93-09510\end{array}$ & $\begin{array}{l}50626-135-16 \\
27-J u l-93 \\
93-09501\end{array}$ \\
\hline & & Concentration, $\mathrm{mg} / \mathrm{L}$ & Analyzed & eachate Conce & ation, mg/L & Leachate Con & ntration, $\mathrm{mg} / \mathrm{L}$ \\
\hline & $\mathrm{N}(0.002)(\mathrm{a})$ & 6.16 & 6.44 & 5.83 & 4.75 & 5.30 & 5.28 \\
\hline & $B(0.02)$ & 33.0 & 32.8 & 30.3 & 41.6 & 36.9 & 35.2 \\
\hline & $\begin{array}{l}\mathrm{Ba}(0.0005) \\
\mathrm{Ca}(0.01) \\
\mathrm{Cd}(0.001) \\
\mathrm{Co}(0.001)\end{array}$ & (b) 0.0015 & . & & 0.0010 & & \\
\hline & $\operatorname{Cr}(0.002)$ & 0.012 & 0.015 & 0.013 & 0.023 & 0.026 & 0.028 \\
\hline & $\mathrm{Cu}(0.0005)$ & 0.012 & 0.049 & 0.0354 & 0.0013 & 0.0018 & 0.0028 \\
\hline & Fe $(0.005)$ & 0.26 & 0.19 & 0.15 & 0.19 & 0.310 & 0.388 \\
\hline & $K(0.2)$ & 16.6 & 13.5 & 12.8 & 17.3 & 12.6 & 13 \\
\hline & L ن (0.003) & 12.4 & 12.6 & 12.5 & 14.2 & 10.7 & 11.1 \\
\hline & $\mathrm{Mg}(0.005)$ & 0.090 & 0.061 & 0.066 & 0.116 & 0.051 & 0.054 \\
\hline & Mn $(0.0005)$ & 0.0592 & 0.05 & 0.0476 & 0.0529 & 0.0362 & 0.0426 \\
\hline & Mo (0.003) & 0.109 & 0.112 & 0.109 & & 0.103 & 0.103 \\
\hline & $\mathrm{Na}(0.05)$ & 40.5 & 41.5 & 40.7 & 58.4 & 35.8 & 36.5 \\
\hline & $\mathrm{Ni}(0.003)$ & 0.018 & 0.015 & 0.015 & 0.024 & 0.010 & 0.011 \\
\hline & $P(0.03)$ & 1.99 & 2.07 & 1.89 & 1.92 & 1.78 & 1.78 \\
\hline & Si $(0.01)$ & 49.6 & 52.1 & 47.2 & 50.6 & 38.3 & 38.1 \\
\hline & Sr $(0.0005)$ & 0.0010 & & & 0.0024 & & \\
\hline & $\mathrm{Ti}(0.001)$ & 0.012 & 0.010 & 0.010 & 0.006 & 0.010 & 0.011 \\
\hline & $\mathrm{Zn}(0.003)$ & 0.012 & 0.004 & 0.016 & 0.026 & 0.086 & \\
\hline & $Z(0.001)$ & 0.032 & 0.026 & 0.030 & 0.018 & 0.027 & 0.031 \\
\hline & Dilution Factor (c) & $1 \times$ & $1 x$ & $1 x$ & $1 x$ & $1 \mathrm{x}$ & $1 x$ \\
\hline & $\begin{array}{l}\text { (b) Absence of numbe } \\
\text { (c) All results have be }\end{array}$ & $\begin{array}{l}\text { icates "below det } \\
\text { rected for dilutior }\end{array}$ & s. & & & & \\
\hline
\end{tabular}


Table 3.5. (contd)

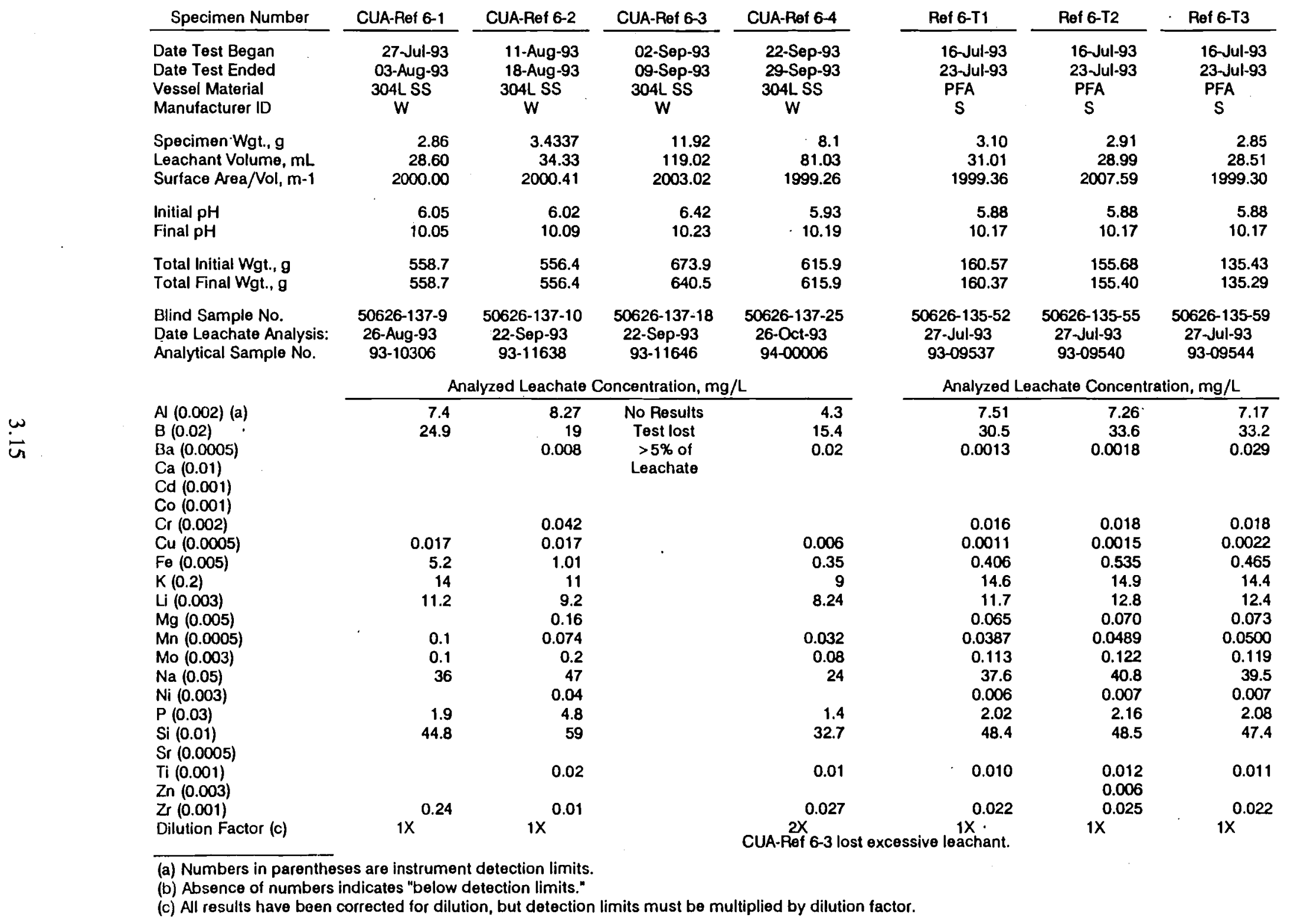


Table 3.6. Test Information and Leachate Analysis for Blanks

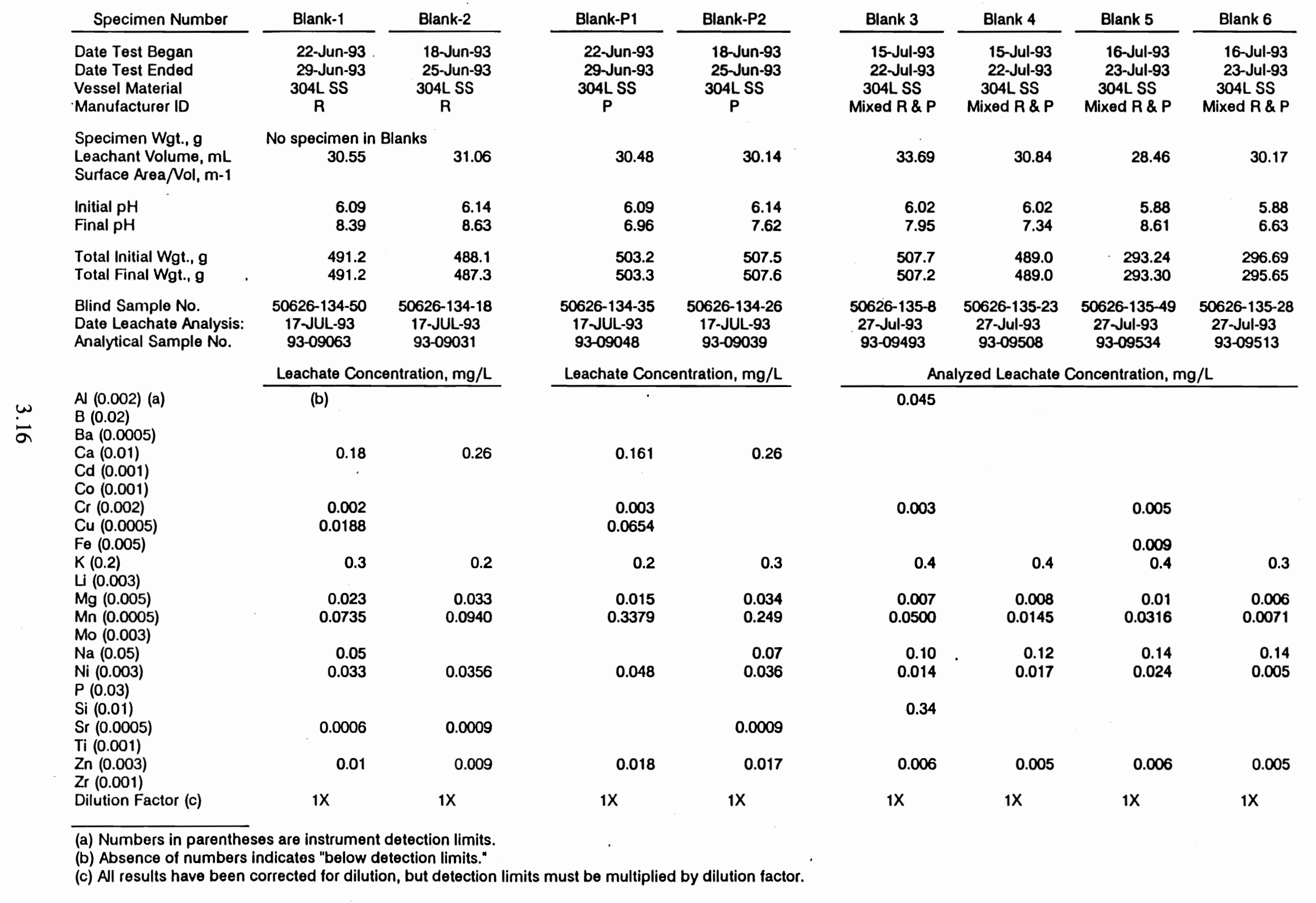


Table 3.6. (contd)

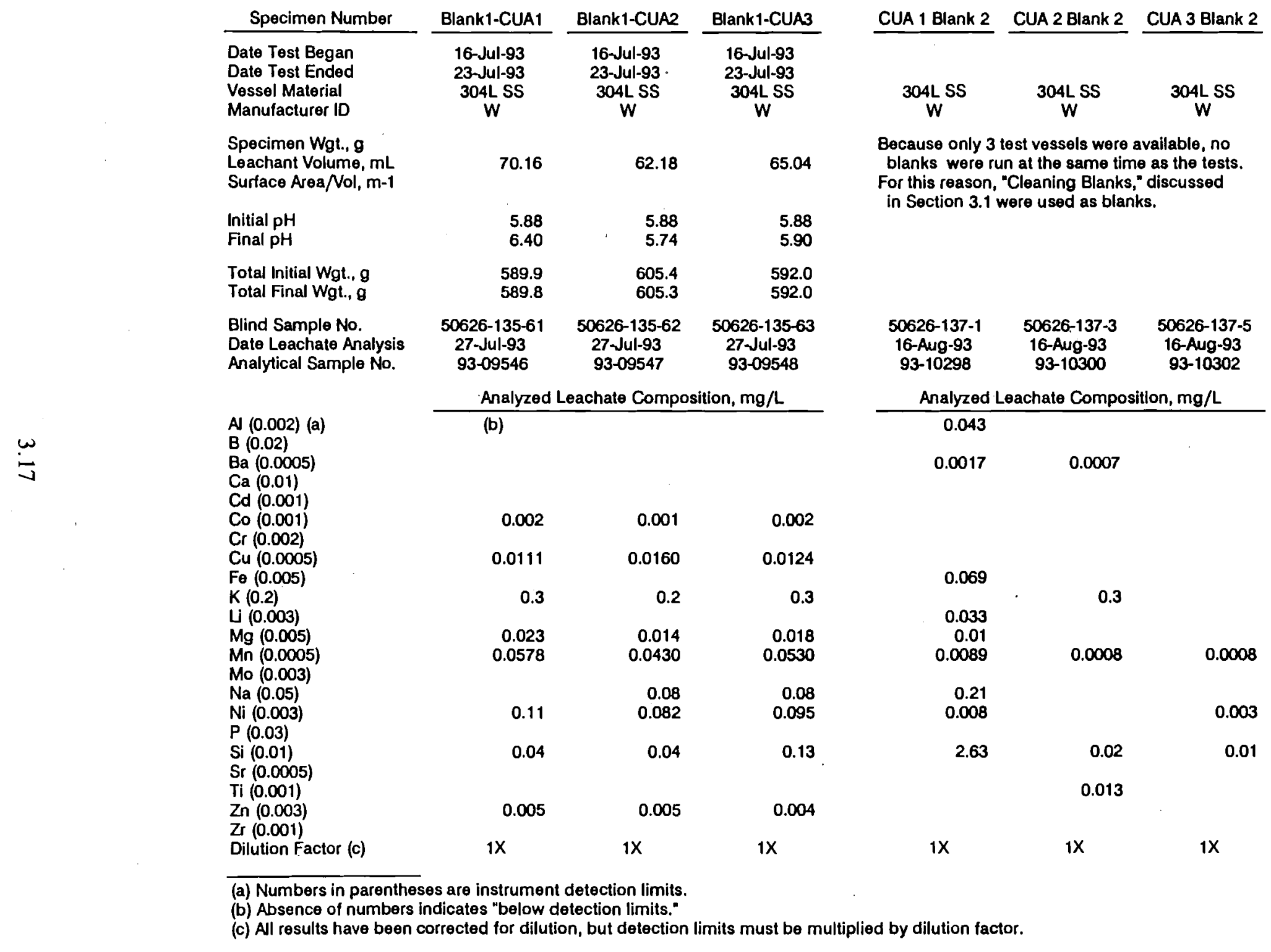


Table 3.6. (contd)

\begin{tabular}{|c|c|c|c|c|c|c|}
\hline Specimen Number & CuAt Blank 3 & CUA2 Blank 3 & CUA 3 Blank 3 & CUA 1 Blank 4 & CUA 2 Blank 4 & CUA 3 Blank 4 \\
\hline $\begin{array}{l}\text { Date Test Began } \\
\text { Date Test Ended } \\
\text { Vessel Material } \\
\text { Manufacturer ID }\end{array}$ & $\begin{array}{c}304 L \text { SS } \\
W\end{array}$ & $\begin{array}{c}\text { 304L SS } \\
W\end{array}$ & $\underset{W}{304 L S S}$ & $\begin{array}{c}304 \mathrm{~L} S S \\
W\end{array}$ & $\underset{W}{304 L S S}$ & $\begin{array}{c}304 L S S \\
W\end{array}$ \\
\hline $\begin{array}{l}\text { Specimen Wgt., g } \\
\text { Leachant Volume, } \mathrm{mL} \\
\text { Surface Area/Nol, } \mathrm{m}-1\end{array}$ & \multicolumn{6}{|c|}{$\begin{array}{l}\text { Because only } 3 \text { test vessels were avallable, no blanks could be run at the same time as the tests. } \\
\text { For this reason, "Cleaning Blanks," discussed in Section } 3.1 \text { were used as blanks. }\end{array}$} \\
\hline $\begin{array}{l}\text { Initial pH } \\
\text { Final pH }\end{array}$ & & & & & & \\
\hline $\begin{array}{l}\text { Total Initial Wgt., g } \\
\text { Total Final Wgt., g }\end{array}$ & & & & & & \\
\hline \multirow[t]{2}{*}{$\begin{array}{l}\text { Blind Sample No. } \\
\text { Date Leachate Analysis } \\
\text { Analytical Sample No. }\end{array}$} & $\begin{array}{c}50626-137-13 \\
22-S \ominus p-93 \\
93-11641\end{array}$ & $\begin{array}{c}50626-137-16 \\
22-5 e p-93 \\
93-11644\end{array}$ & $\begin{array}{c}50626-137-15 \\
22-S e p-93 \\
93-11643\end{array}$ & $\begin{array}{l}50626-137-20 \\
26-0 c t-93 \\
94-00001\end{array}$ & $\begin{array}{l}50626-137-21 \\
26-0 c t-93 \\
94-00002\end{array}$ & $\begin{array}{c}50626-137-22 \\
26-0 c t-93 \\
94-00003\end{array}$ \\
\hline & \multicolumn{3}{|c|}{ Analyzed Leachate Concentration, $\mathrm{mg} / \mathrm{L}$} & \multicolumn{3}{|c|}{ Analyzed Leachate Concentration, $\mathrm{mg} / \mathrm{L}$} \\
\hline $\begin{array}{l}\mathrm{A}(0.002)(\mathrm{a}) \\
\mathrm{B}(0.02) \\
\mathrm{Ba}(0.0005) \\
\mathrm{Ca}(0.01) \\
\mathrm{Cd}(0.001) \\
\mathrm{Co}(0.001) \\
\mathrm{Cr}(0.002) \\
\mathrm{Cu}(0.0005)\end{array}$ & $\begin{array}{l}\text { (b) } \\
0.0023\end{array}$ & 0.0026 & & & 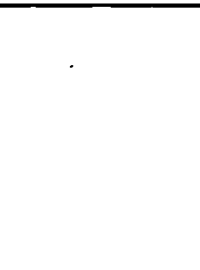 & \\
\hline $\begin{array}{l}F \theta(0.005) \\
K(0.2) \\
U(0.003) \\
M g(0.005)\end{array}$ & 0.3 & 0.4 & 0.5 & 0.4 & $\begin{array}{r}0.009 \\
0.5\end{array}$ & $\begin{array}{r}0.01 \\
0.6\end{array}$ \\
\hline $\begin{array}{l}\text { Mn }(0.0005) \\
\text { Mo }(0.003)\end{array}$ & 0.0037 & 0.0094 & 0.0023 & 0.0023 & 0.0111 & 0.022 \\
\hline $\begin{array}{l}\mathrm{Na}(0.05) \\
\mathrm{Ni}(0.003) \\
\mathrm{P}(0.03)\end{array}$ & 0.07 & 0.12 & 0.1 & $\begin{array}{r}0.09 \\
0.009\end{array}$ & $\begin{array}{r}0.08 \\
0.011\end{array}$ & 0.008 \\
\hline $\begin{array}{l}\text { Si }(0.01) \\
\text { Sr }(0.0005) \\
\operatorname{Ti}(0.001) \\
\operatorname{Zn}(0.003) \\
\operatorname{Zr}(0.001)\end{array}$ & $\begin{array}{r}0.02 \\
0.0018\end{array}$ & 0.06 & 0.03 & 0.04 & 0.04 & 0.09 \\
\hline Dilution Factor (c) & $1 X$ & $1 X$ & $1 X$ & $1 X$ & $1 X$ & $1 X$ \\
\hline
\end{tabular}


Table 3.6. (contd)

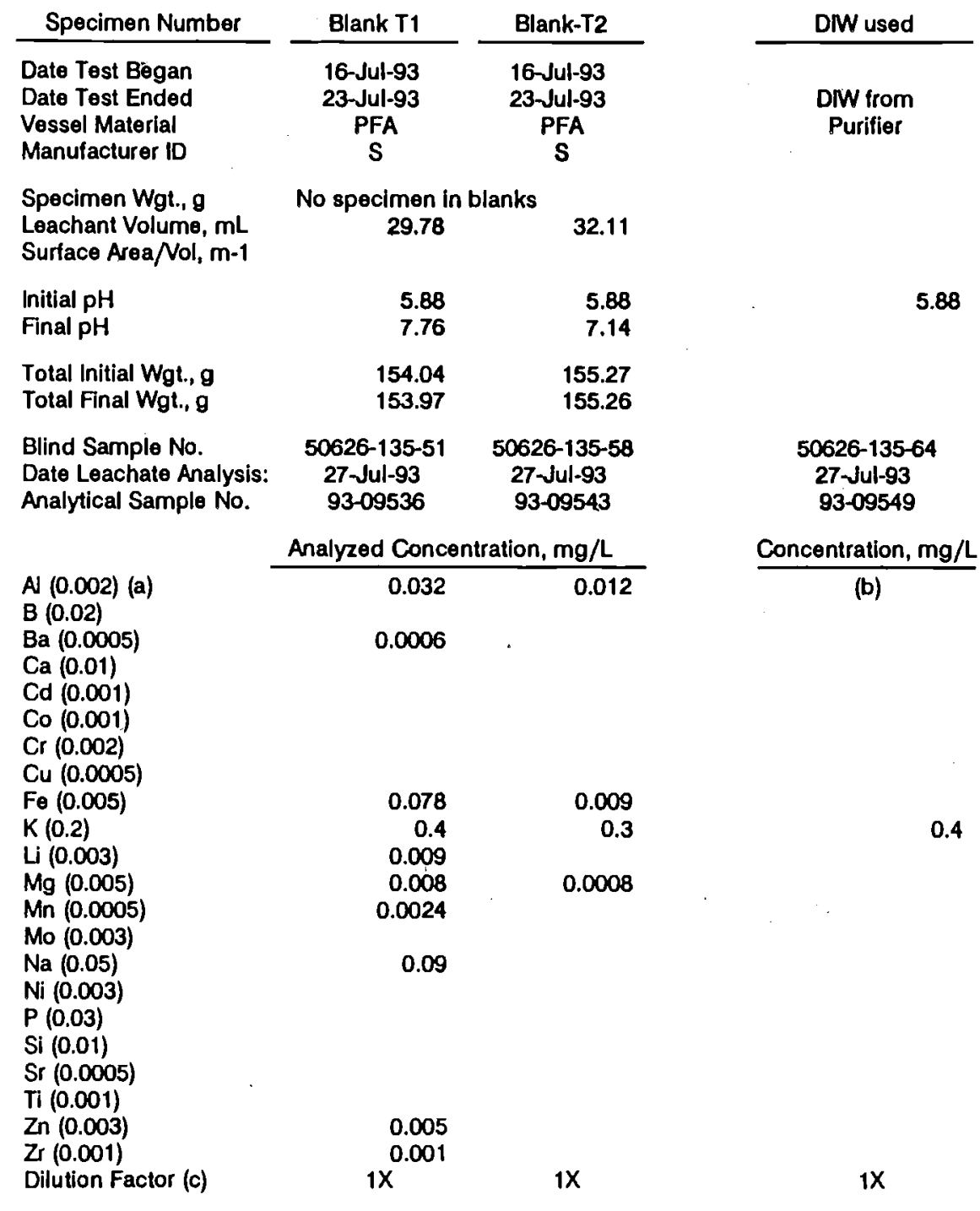

(a) Numbers in parentheses are instrument detection limits.

(b) Absence of numbers indicates "below detection limits."

(c) All results have been corrected for dilution, but detection limits must be multiplied by dilution factor. 


\subsection{Results and Discussion}

This section discusses the differences found in the durability test results obtained by using different types of test vessels. Also presented are the results of metallography and scanning electron microscopy (SEM) examinations of new and used stainless steel test vessels.

\subsection{Durability Testing}

The most striking difference in the leaching data is the contrast between EA glass and WVNS reference glasses 5 and 6 . As shown in Table 4.1, the leachates from the EA glass showed higher levels of $\mathrm{B}, \mathrm{Li}, \mathrm{Na}$, and $\mathrm{Si}$ than the other two glasses by a magnitude of at least 10 . These results were expected because the $\mathrm{pH}$ of the EA glass leachates is so much higher $(\approx 11.9)$ than the $\mathrm{pH}$ of the WVNS references glasses 5 and $6(\approx 10.2)$, and the leachate $\mathrm{pH}$ is known to have a strong correlation with leaching durability. Generally, a higher $\mathrm{pH}$ indicates a less durable glass; this is true of the EA glass in these tests.

However, there were no significant differences in leachate $\mathrm{pH}$ or elemental concentration levels when leaching any one of the glasses, EA glass or WVNS reference glasses 5 or 6 , in the several types of test vessels. As shown in Table 4.1, the $\mathrm{pH}$ values and average leachate concentrations of $\mathrm{B}, \mathrm{Li}$, $\mathrm{Na}$, and $\mathrm{Si}$ were similar for each of the three glasses in the various vessel types. This means that the effects of $\mathrm{CO}_{2}$, which might be expected to be more concentrated in the PFA vessels that are permeable to the atmosphere, were smaller than experimental error. In fact, for each of the three glasses, the vessels that produced leachates with the highest $\mathrm{pH}$ (the difference was very small) were never the same vessels that produced leachates with the highest average leachate concentrations of $\mathrm{B}, \mathrm{Li}, \mathrm{Na}$, and $\mathrm{Si}$ (again, the differences were very small).

The data for each glass are plotted in Figures 4.1 to 4.5 for EA glass leachates, Figures 4.6 to 4.10 for WVNS reference glass 5 leachates, and Figures 4.11 to 4.15 for WVNS reference glass 6 leachates. These data clearly show that there was no trend toward different results based on the leaching vessels used. The test results for the EA glass agree with results that had been produced by Xing and Pegg (1984).

One might think that the size of the error bars in Figures 4.1 through 4.15 would provide a better comparison of the values in each case. However, in comparing these values, note whether the tests were begun on the same or on different days (see Table 4.1). The tests in type $S$ vessels were all begun the same day in July; as expected, the error bars for these tests are generally very small. All of the tests in types $R$ and $P$ vessels were part of a test series begun on two separate, non-consecutive days in June. These vessels were cleaned and reused for tests in mixed $R$ and $P$ vessels, which were begun on two separate, consecutive days in July. As expected, the error bars for the tests using R or P or mixed $R$ and $P$ vessels are generally slightly larger than those of the type $S$ vessels. Tests conducted in the type $\mathrm{W}$ vessels (August and September) were not part of any series. Only 3 type W vessels were available. Because of this, they were cleaned and used at four different times, testing each of the three different glasses each time in a different vessel. Because the tests in type $\mathrm{W}$ vessels were started at 
Table 4.1. Average Elemental Leachate Concentrations and pH Values

\begin{tabular}{|c|c|c|c|c|c|c|c|}
\hline Glass & No. Tests & Vessel Type & $\begin{array}{c}\mathrm{pH} \\
\text { Av Value } \\
\end{array}$ & $\begin{array}{l}\text { B Av } \\
\mathrm{mg} / \mathrm{L}\end{array}$ & $\begin{array}{l}\mathrm{UAV} \\
\mathrm{mg} / \mathrm{L}\end{array}$ & $\begin{array}{l}\mathrm{Na} \mathrm{Av} \\
\mathrm{mg} / \mathrm{L}\end{array}$ & $\begin{array}{l}\text { Si Av } \\
\mathrm{mg} / \mathrm{L}\end{array}$ \\
\hline EA & 6 & $\mathbf{R}$ & 11.99 & 544.33 & 149.50 & 1556.67 & 685.83 \\
\hline EA & 2 & $P$ & 11.97 & 527.50 & 150.50 & 1545.00 & 690.00 \\
\hline EA & 6 & Mixed R \& P & 11.92 & 552.50 & 137.83 & 1515.00 & 632.83 \\
\hline EA & 3 & S & 11.84 & 568.67 & 171.33 & 1600.00 & 869.67 \\
\hline EA & 3 & $W$ & 11.76 & 409.67 & 156.00 & 1275.67 & 780.67 \\
\hline & 6 & D & & & & & \\
\hline Reference 5 & $\begin{array}{l}6 \\
3\end{array}$ & $\begin{array}{l}R \\
P\end{array}$ & $\begin{array}{l}10.19 \\
10.22\end{array}$ & 20.43 & $\begin{array}{l}7.58 \\
7 ? 1\end{array}$ & 41.92 & 51.90 \\
\hline Reference 5 & 3 & ${ }^{P}$ & 10.22 & 19.53 & & 40.23 & 50.43 \\
\hline Reference 5 & 5 & Mixed R \& P & 10.17 & 19.64 & 6.88 & 38.52 & 46.74 \\
\hline Reference 5 & 4 & $\mathrm{~S}$ & 10.17 & 19.93 & 7.57 & 40.93 & 52.37 \\
\hline Reference 5 & 3 & W & 10.09 & 20.25 & 9.91 & 45.00 & 55.98 \\
\hline Reference 6 & 1 & R & 10.09 & 33.00 & 12.40 & 40.50 & 49.60 \\
\hline Reference 6 & 3 & $\mathbf{P}$ & 10.18 & 34.90 & 13.10 & 46.87 & 49.97 \\
\hline Reference 6 & 2 & Mixed R \& P & 10.22 & 36.05 & 10.90 & 36.15 & 38.20 \\
\hline Reference 6 & 3 & $S$ & 10.17 & 32.43 & 12.30 & 39.30 & 48.10 \\
\hline Reference 6 & 3 & W & 10.11 & 19.77 & 9.55 & 35.67 & 45.50 \\
\hline
\end{tabular}




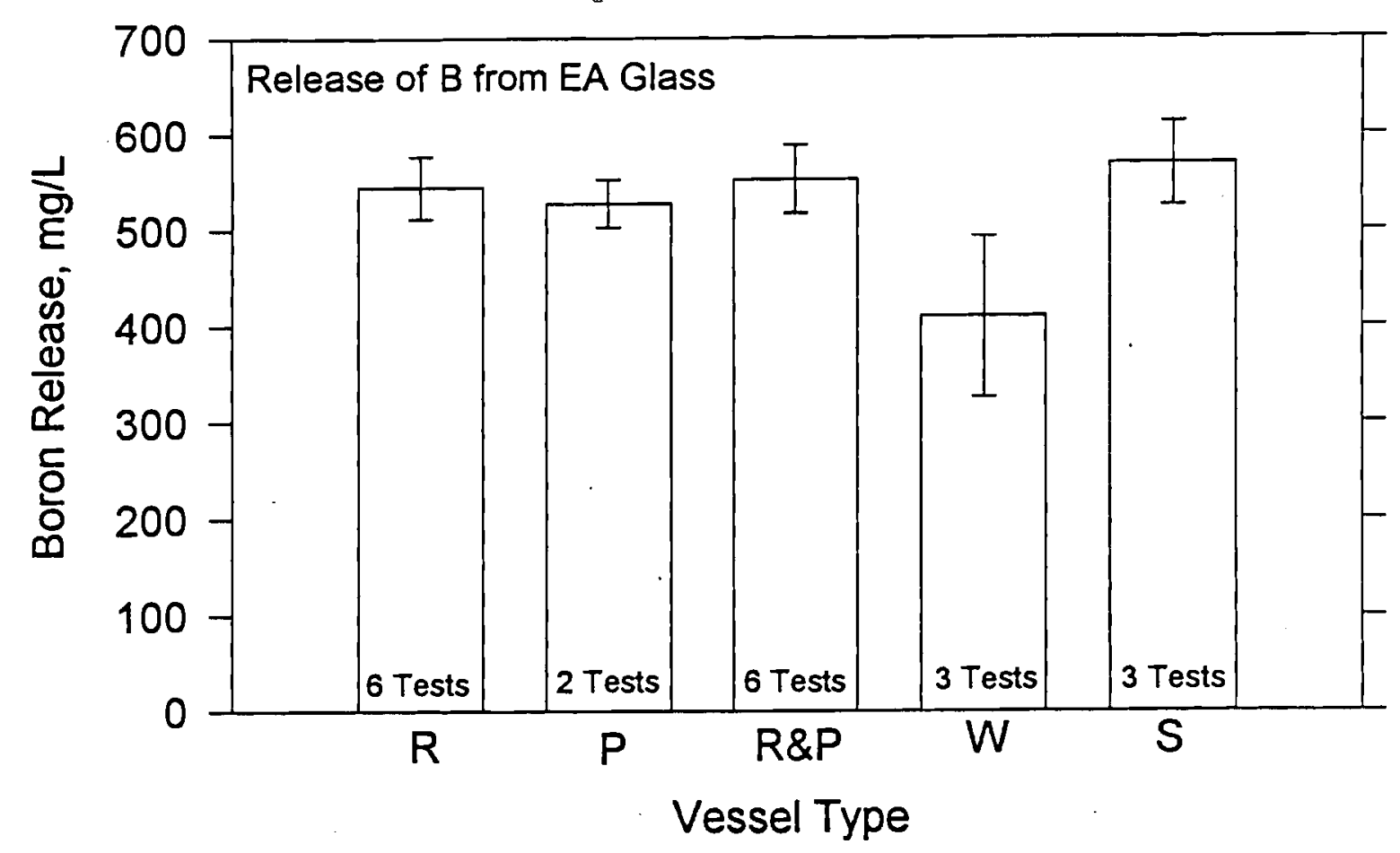

Figure 4.1. Release of Boron From EA Glass

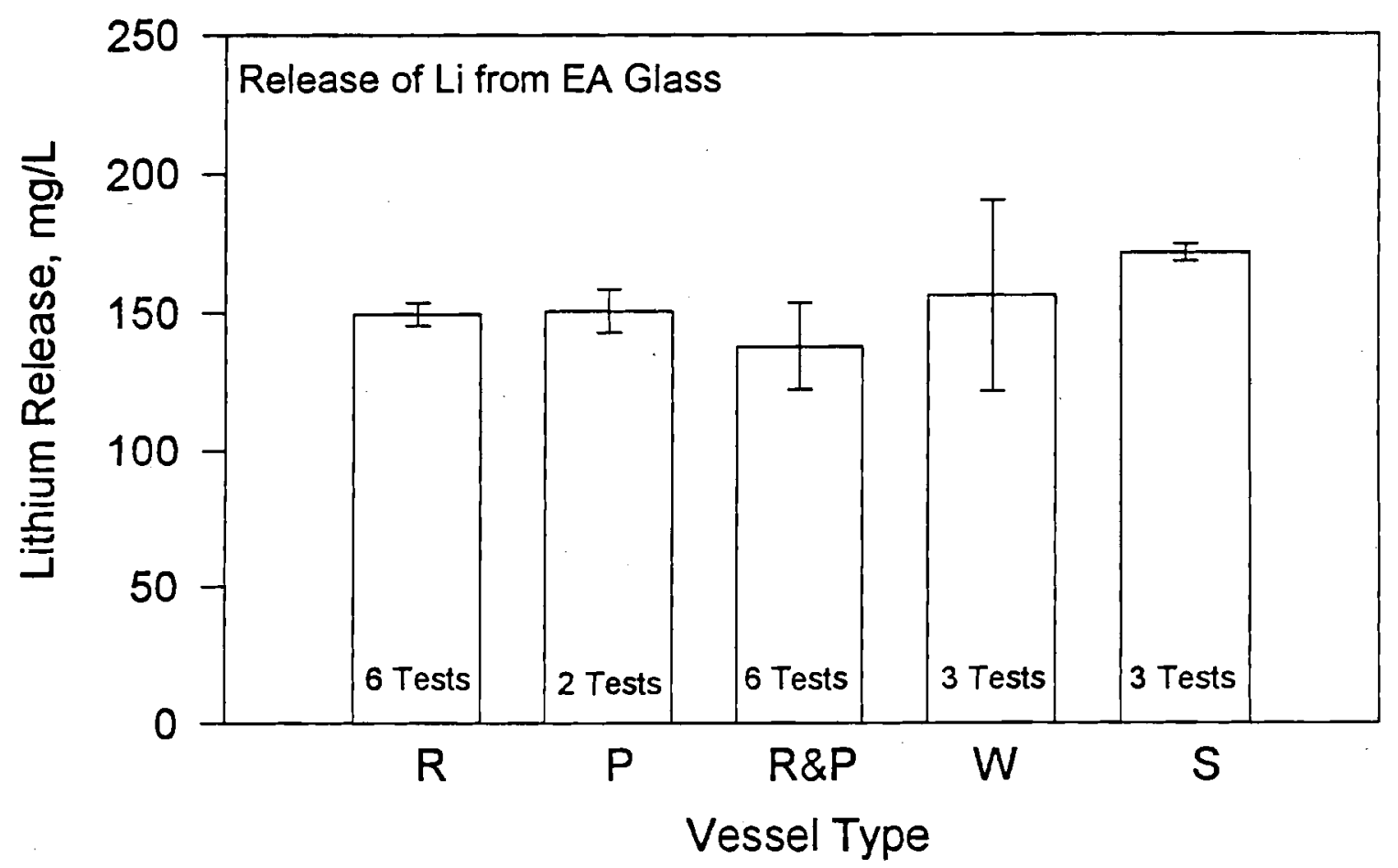

Figure 4.2. Release of Lithium From EA Glass 


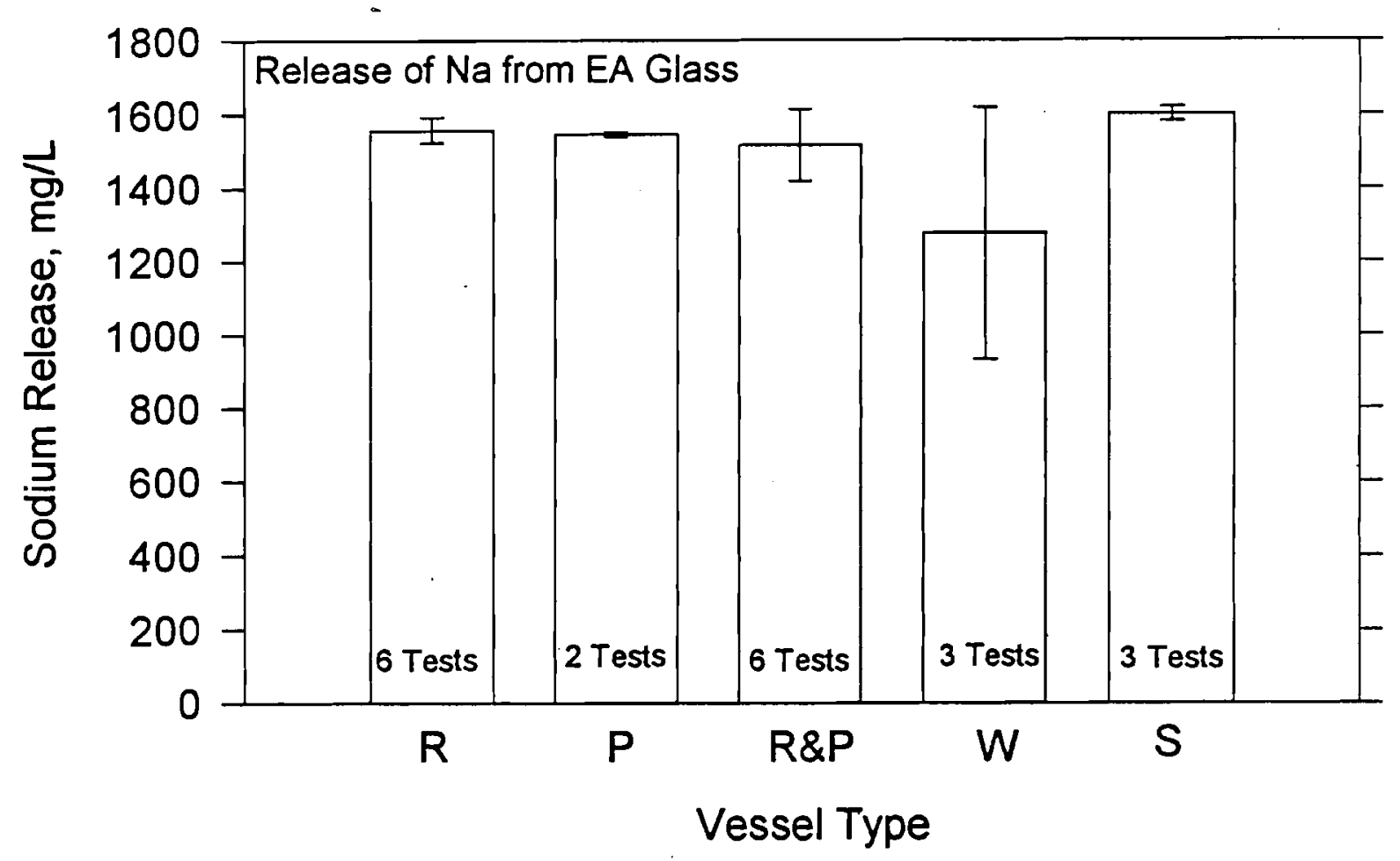

Figure 4.3. Release of Sodium From EA Glass

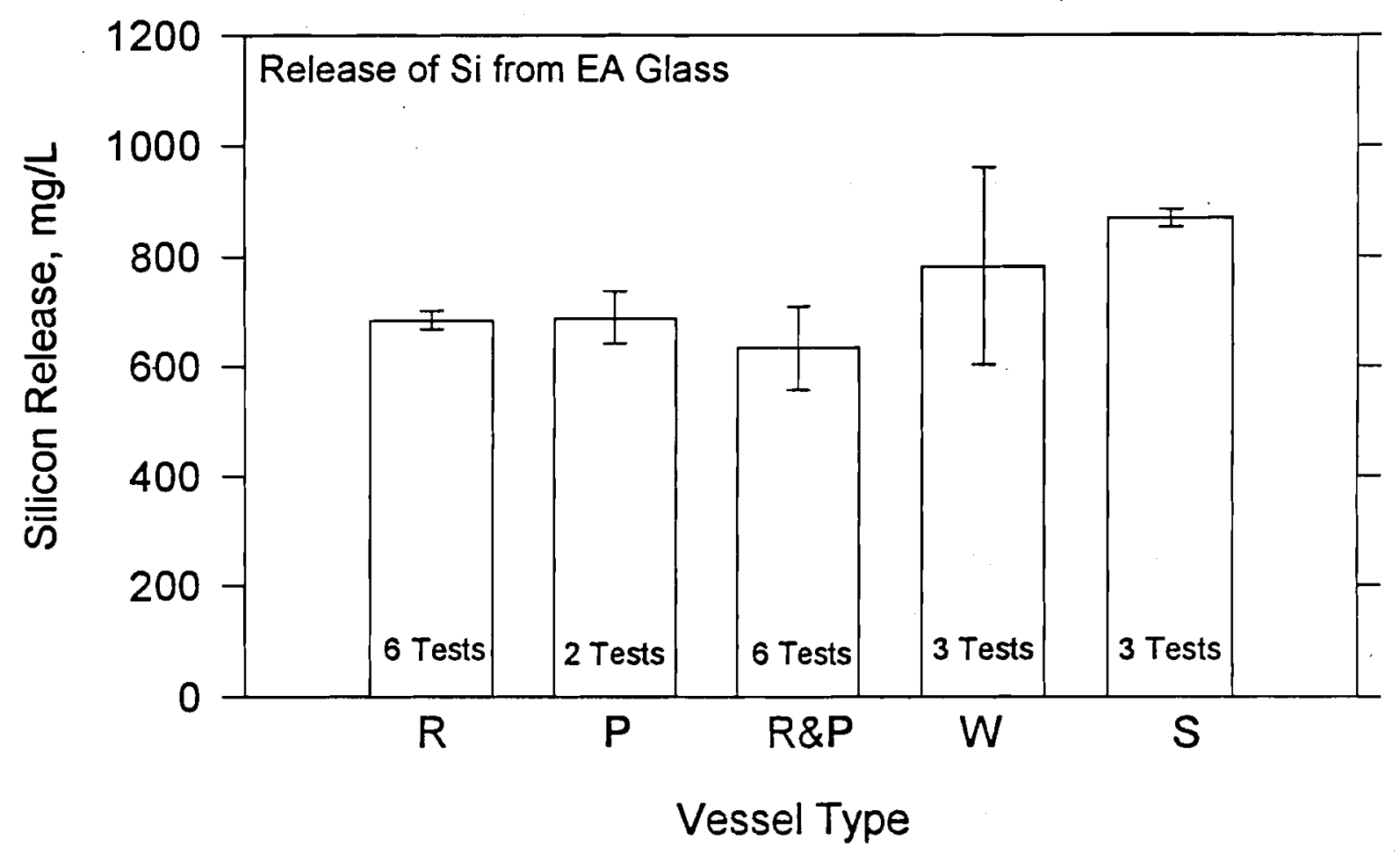

Figure 4.4. Release of Silicon From EA Glass 


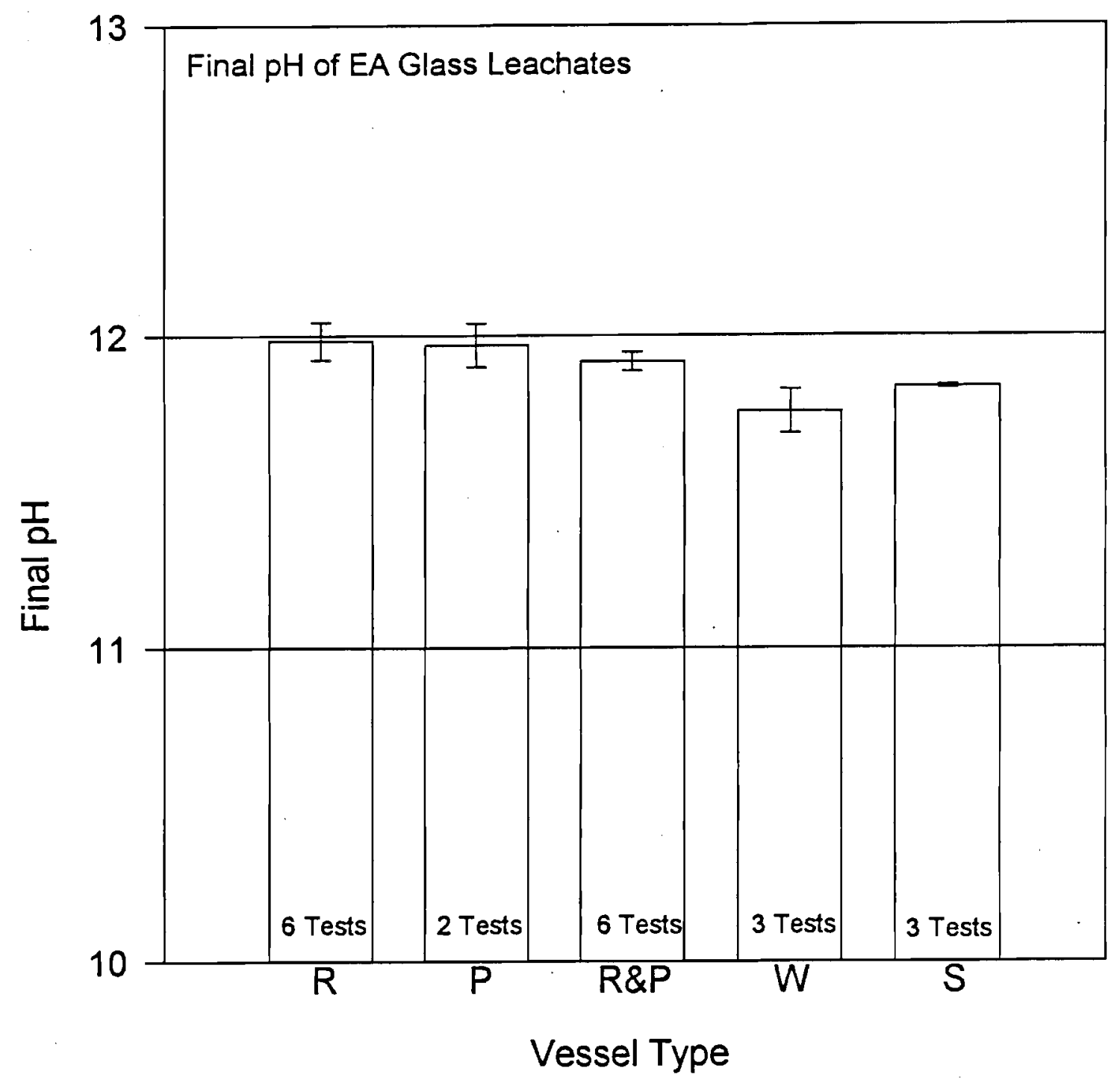

Figure 4.5. Average Leachate $\mathrm{pH}$ After PCTs of EA Glass 


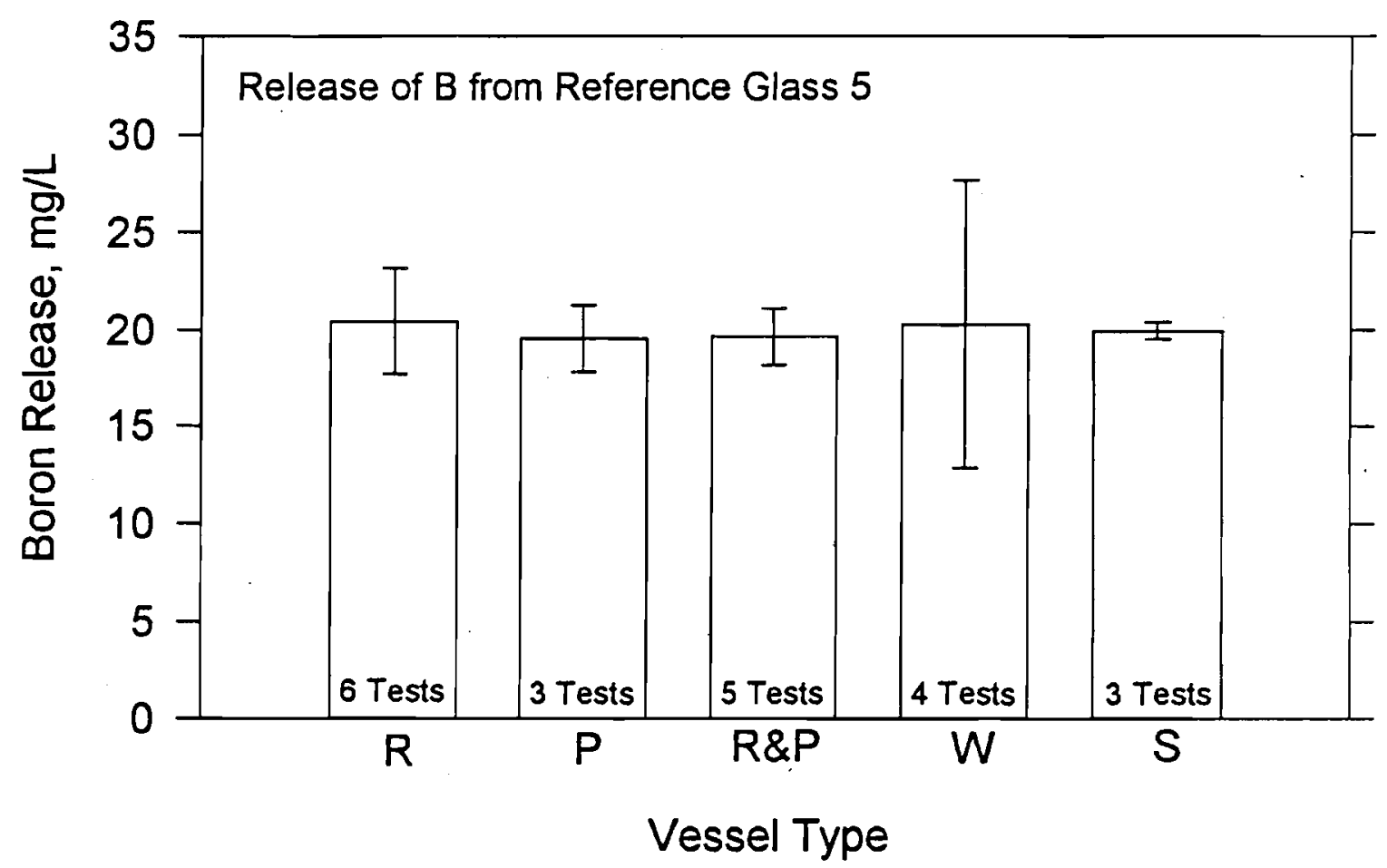

Figure 4.6. Release of Boron From WVNS Reference Glass 5

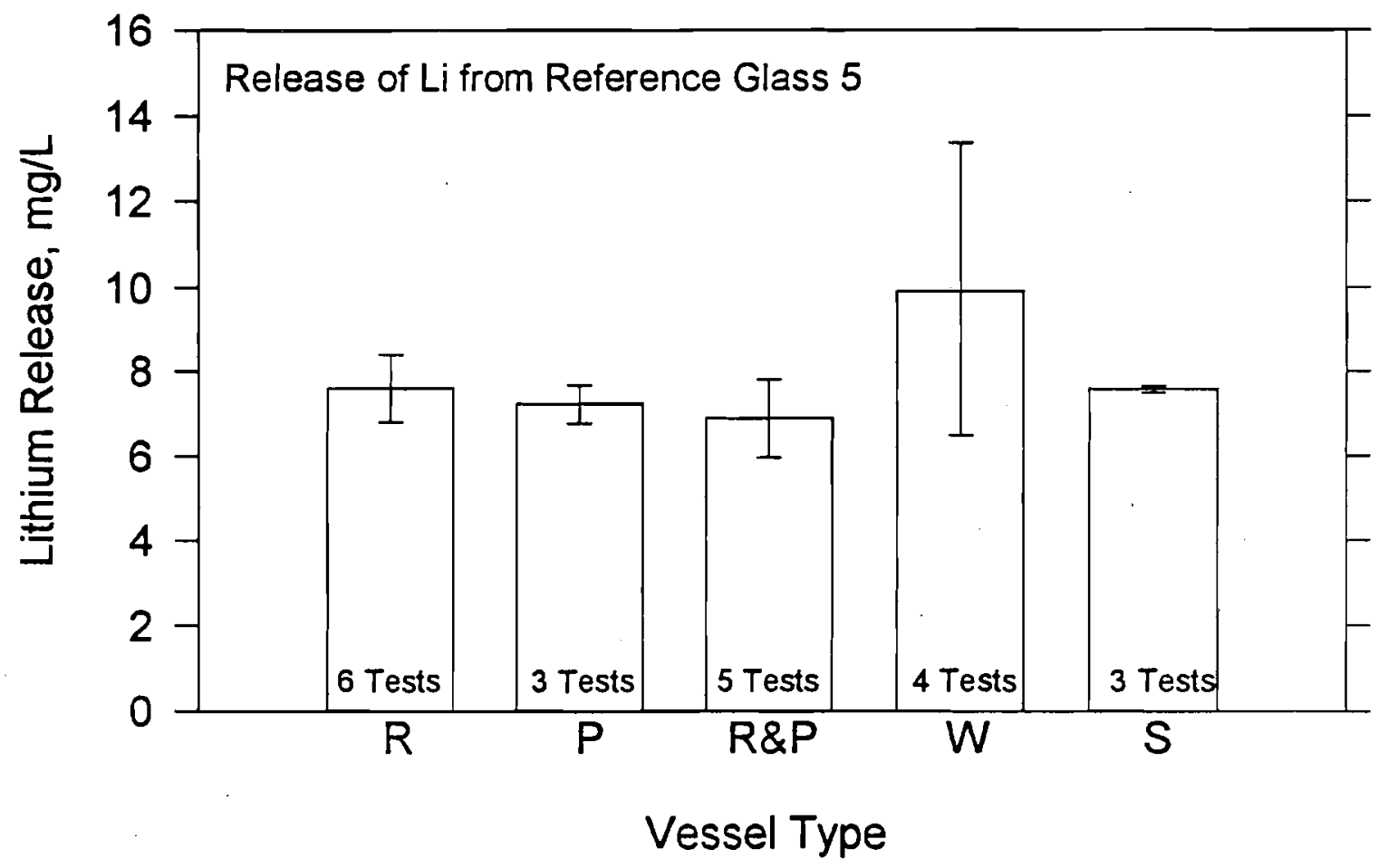

Figure 4.7. Release of Lithium From WVNS Reference Glass 5 


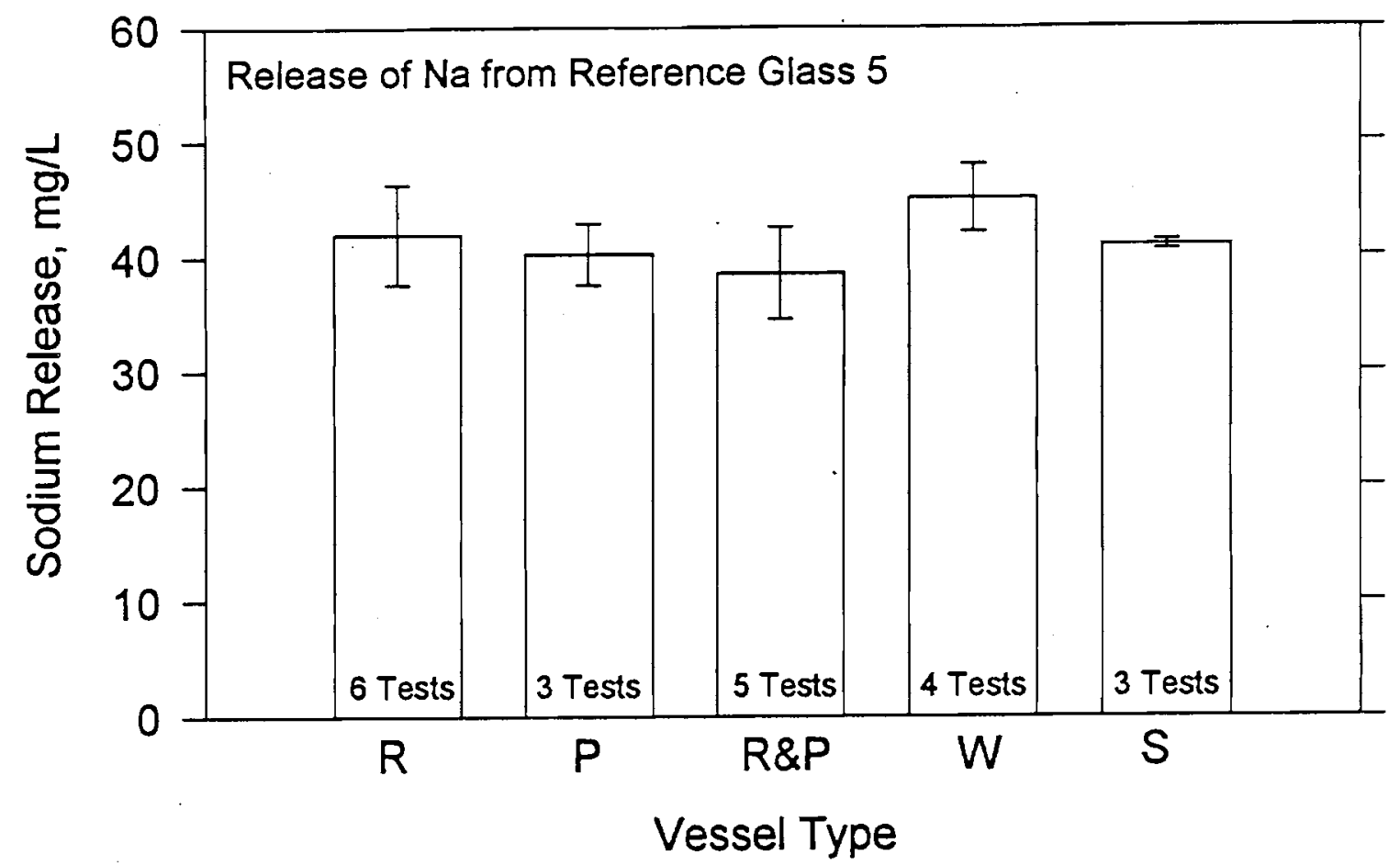

Figure 4.8. Release of Sodium From WVNS Reference Glass 5

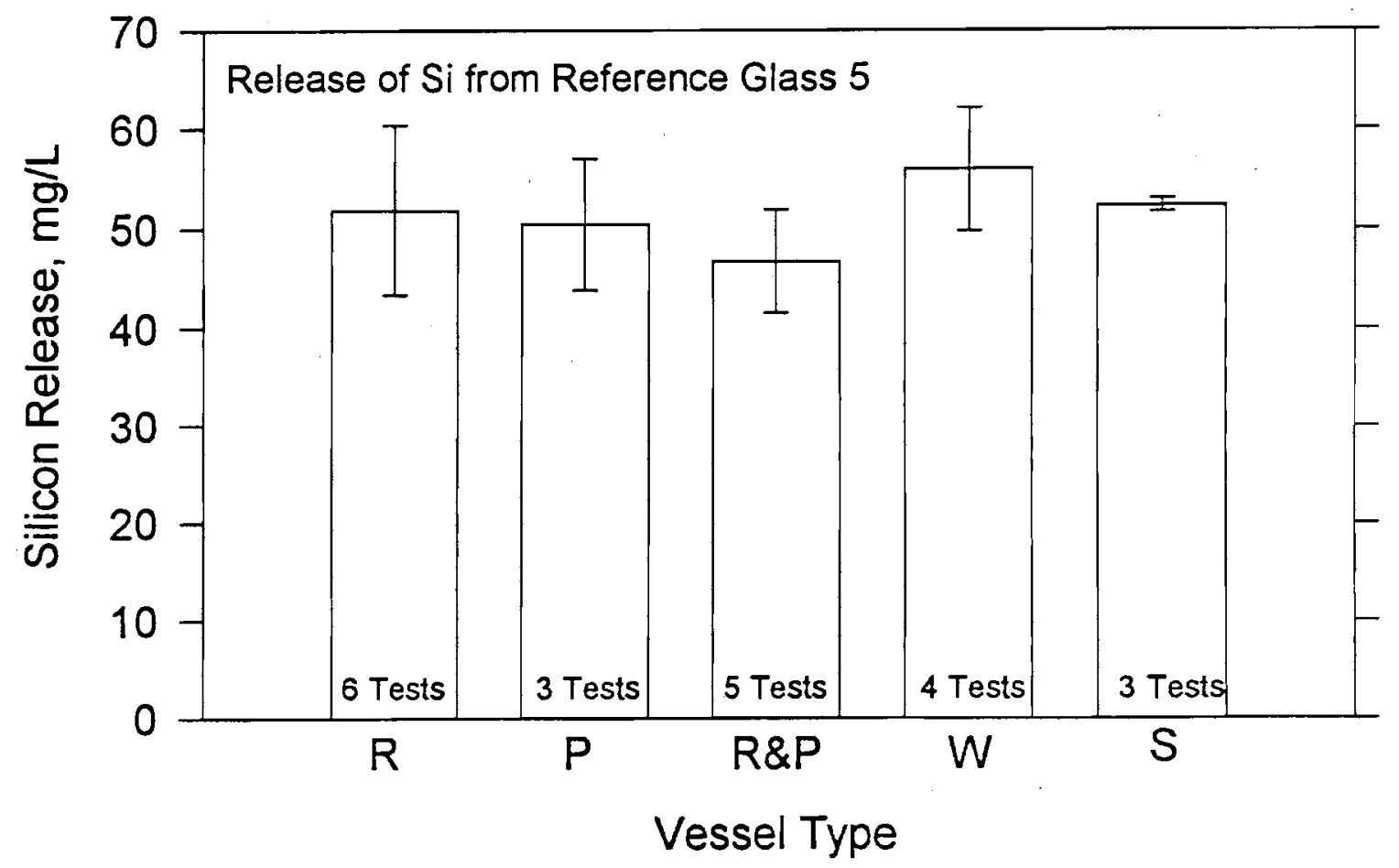

Figure 4.9. Release of Silicon From WVNS Reference Glass 5 


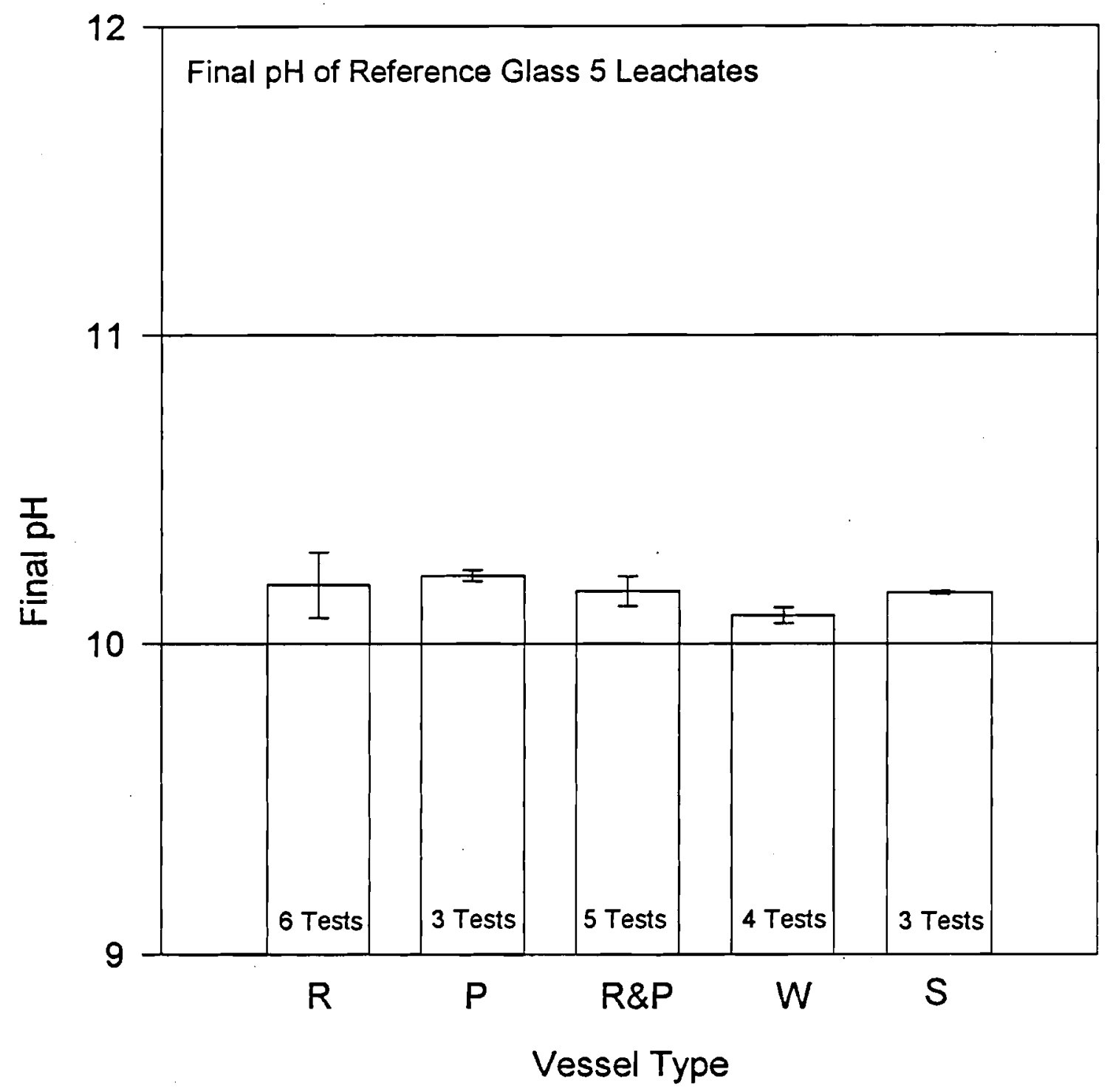

Figure 4.10. Average Leachate pH After PCTs of WVNS Reference Glass 5 


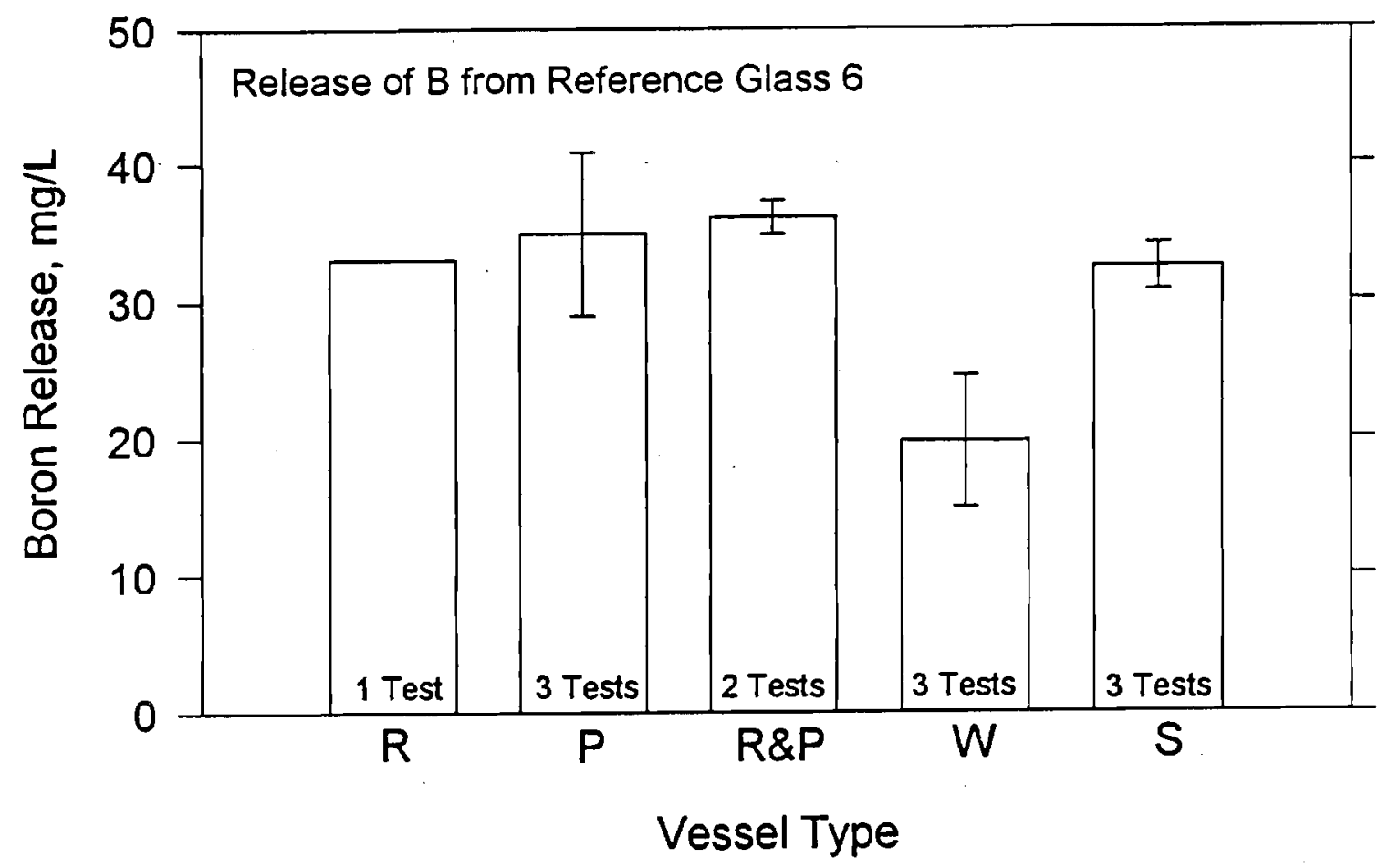

Figure 4.11. Release of Boron From WVNS Reference Glass 6

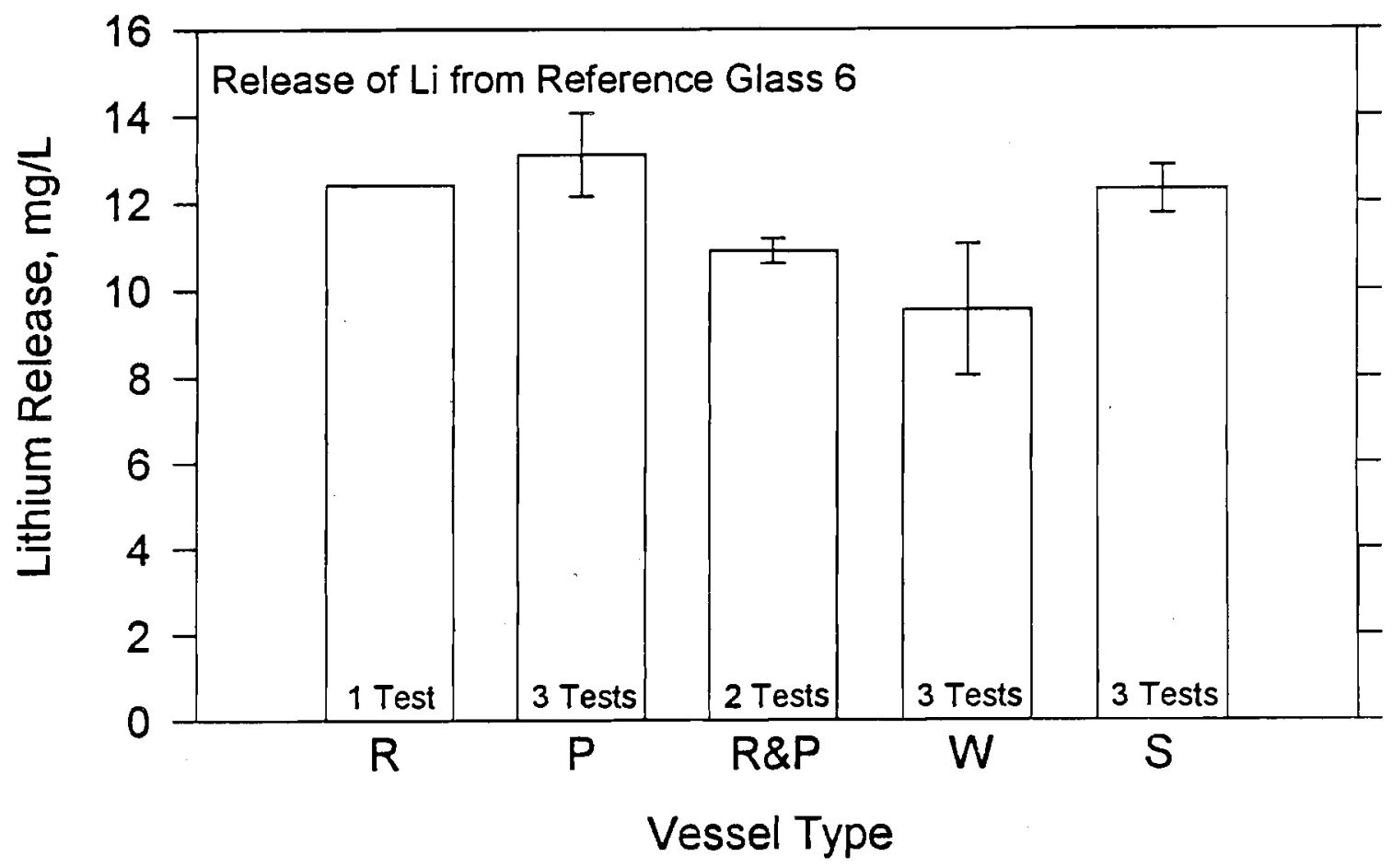

Figure 4.12. Release of Lithium From WVNS Reference Glass 6 


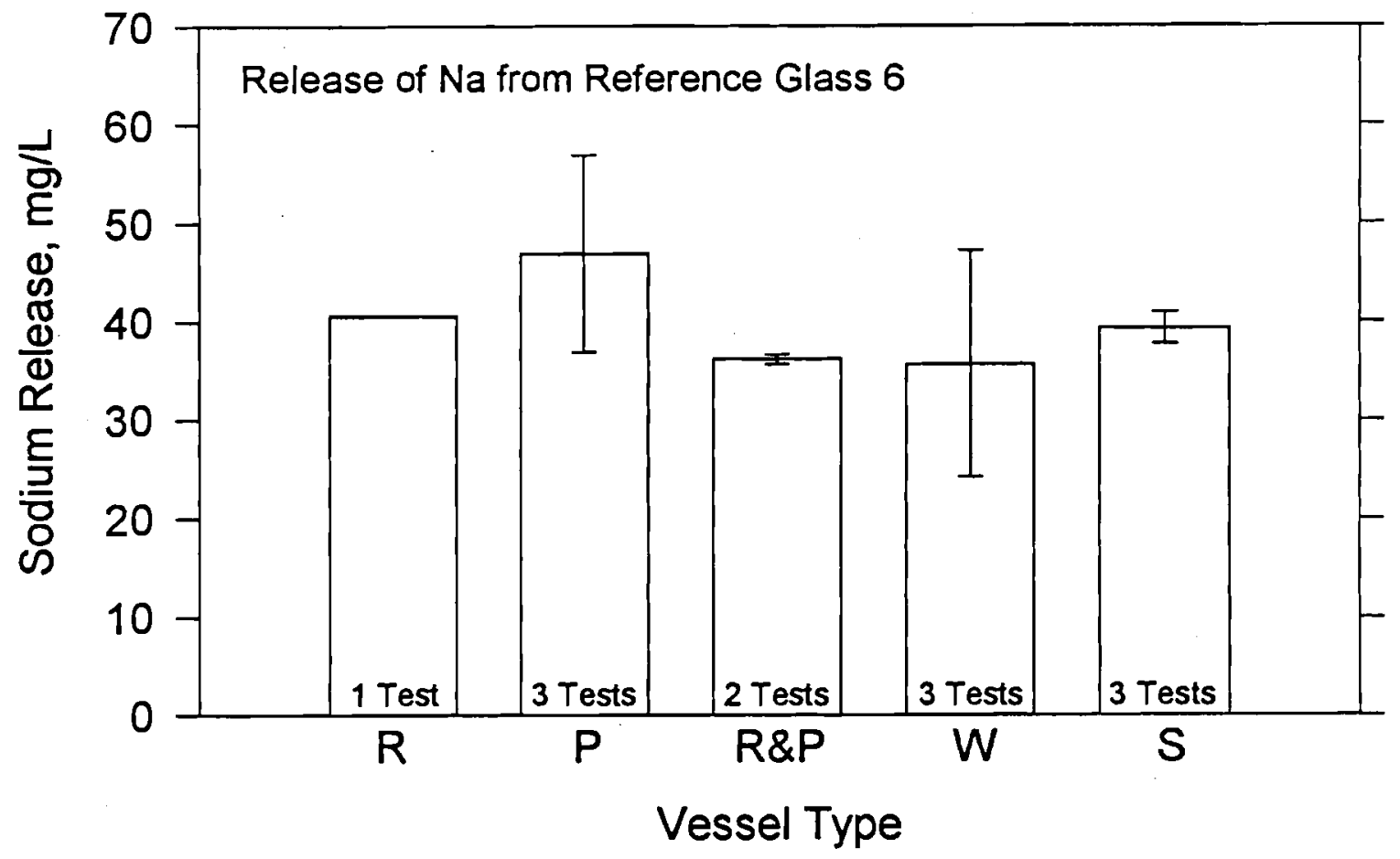

Figure 4.13. Release of Sodium From WVNS Reference Glass 6

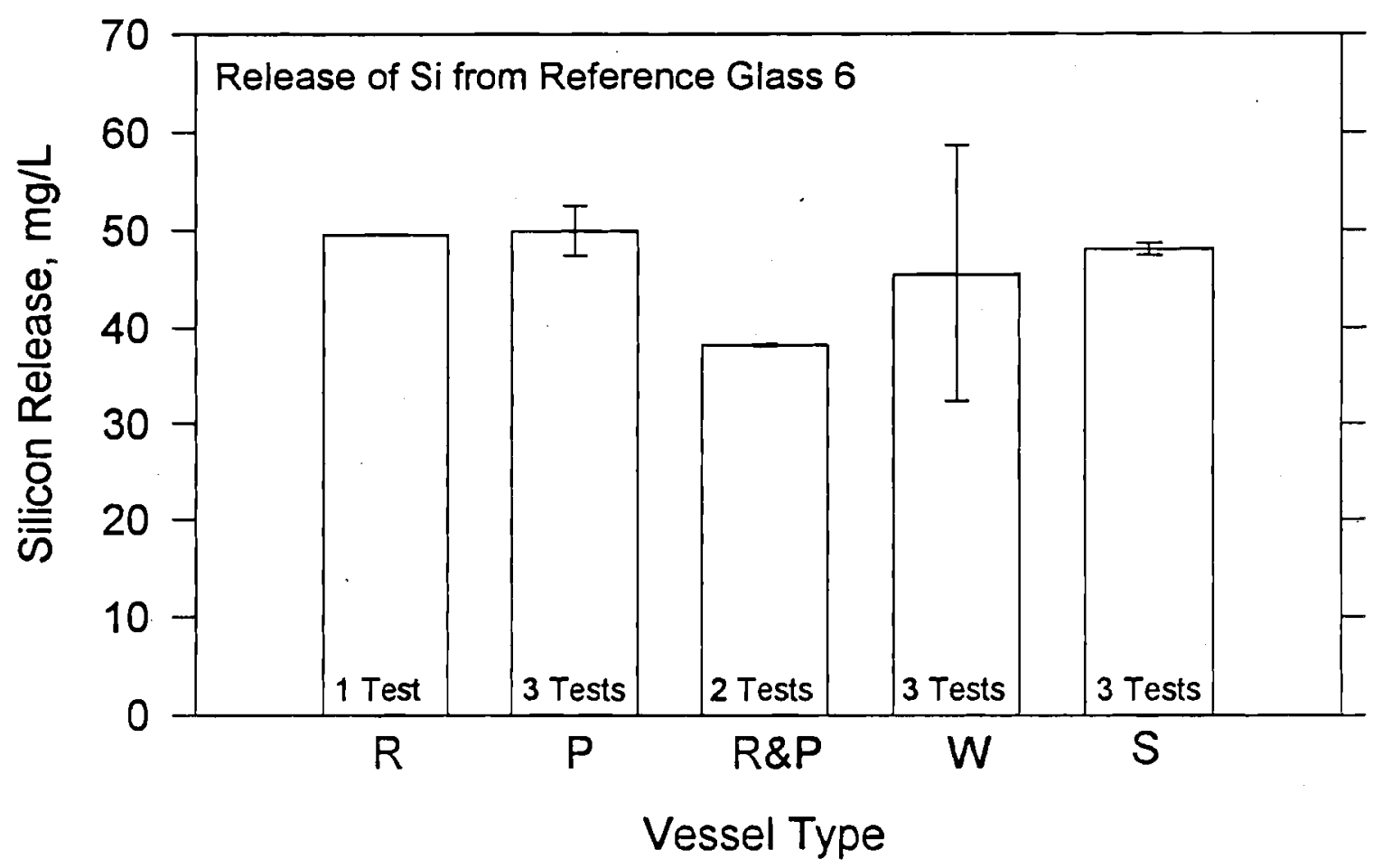

Figure 4.14. Release of Silicon From WVNS Reference Glass 6 


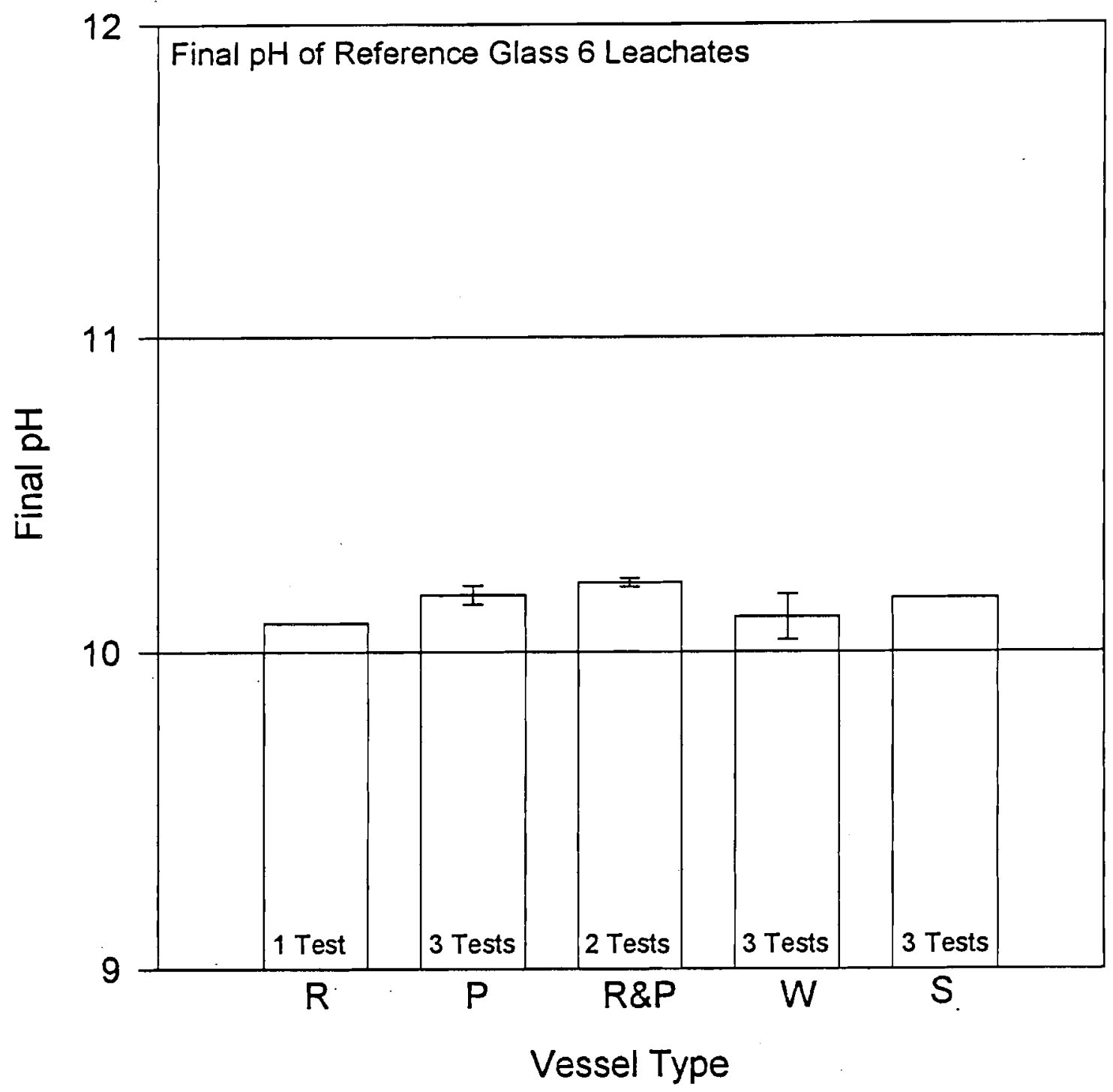

Figure 4.15. Average Leachate pH After PCTs of WVNS Reference Glass 6 
approximately 2-week intervals, the error bars for leachates from these test vessels were generally the largest. Consequently, more error is introduced by using the various PCT vessels at different start times than by using different vessel materials.

In addition to the start dates, the error bars for the type $W$ vessel data are the largest for two reasons: 1) The type $W$ vessels were more difficult to load because of the narrow ends (see Figure 3.2, sample and leachant were loaded through a small funnel). 2) Operator inexperience with type $\mathrm{W}$ vessels affected the test results. During one test cycle, two of the three type $\mathrm{W}$ vessels lost greater than $10 \%$ of the leachant through the threads at the vessel ends. A double thickness of fresh Teflon tape should have been used each time to prevent leakage. Therefore, the fact that the largest error bars were exhibited by the type $\mathrm{W}$ vessel data does not necessarily indicate these vessels are inferior. The error bars shown in Figures 4.1 through 4.15 generally reflect testing variability based on start dates, rather than on vessel type.

Head space was varied only in the type $\mathrm{W}$ vessels, because more glass sample and leachant were used during the final tests in those vessels (only a single specimen for each glass had a variation in head space). There was apparently no effect from this variation, as seen in results from type $\mathrm{W}$ vessels in Tables 3.3 to 3.5. Results from type $\mathrm{W}$ vessels were so varied and inconsistent that only a very large and consistent difference in results for the tests with less head space would have been noticeable.

Iron was present in leachates from all three glasses the first time the type $\mathrm{W}$ vessels were used. During successive tests, the amount of $\mathrm{Fe}$ in the leachates dropped. This behavior may have been caused by the rough inside surface of the type W $304 \mathrm{~L}$ stainless steel vessels. Though valid, the initial high values of Fe may be unimportant, since they apparently did not affect $\mathrm{pH}$ values or any other elemental concentration.

\subsection{Metallography}

Metallographic examinations of the two stainless steel vessel types, $\mathrm{P}$ and $\mathrm{W}$, were performed to determine if differences in microstructure existed. Except for the difference in grain size shown in Figures 4.16 and 4.17, no differences were found. The ASTM grain size in Figure 4.16 (a) is $10.8 \mu \mathrm{m}$ and in Figure 4.16 (b) is $10.7 \mu \mathrm{m}$. These values correspond to average grain size of approximately $9 \mu \mathrm{m}$ (ASTM E112-84). The ASTM grain size in Figure 4.17 (a) and (b) is $8.9 \mu \mathrm{m}$; this corresponds to an average grain size of $16 \mu \mathrm{m}$. These differences in microstructure did not affect leaching results.

\subsection{Scanning Electron Microscopy}

The two stainless steel vessel types were examined by SEM; some minor differences were revealed, though they apparently did not affect test results. Straight-on shots of the inner surface of type $P$ vessels showed the machine marks on the new vessels (Figure 4.18). After four testing and cleaning cycles (each cleaning cycle includes a soak in $0.16 \underline{\mathrm{M} \mathrm{HNO}} \mathrm{H}_{3}$ at $90^{\circ} \mathrm{C}$ ), the same machining marks were visible, but etching had occurred and small pits appeared on the inner surface as shown in Figure 4.19. The new type $W$ vessels exhibited a much rougher surface (Figure 4.20). After four test and cleaning cycles, the surface showed some corrosion and pitting as shown in Figure 4.21. 

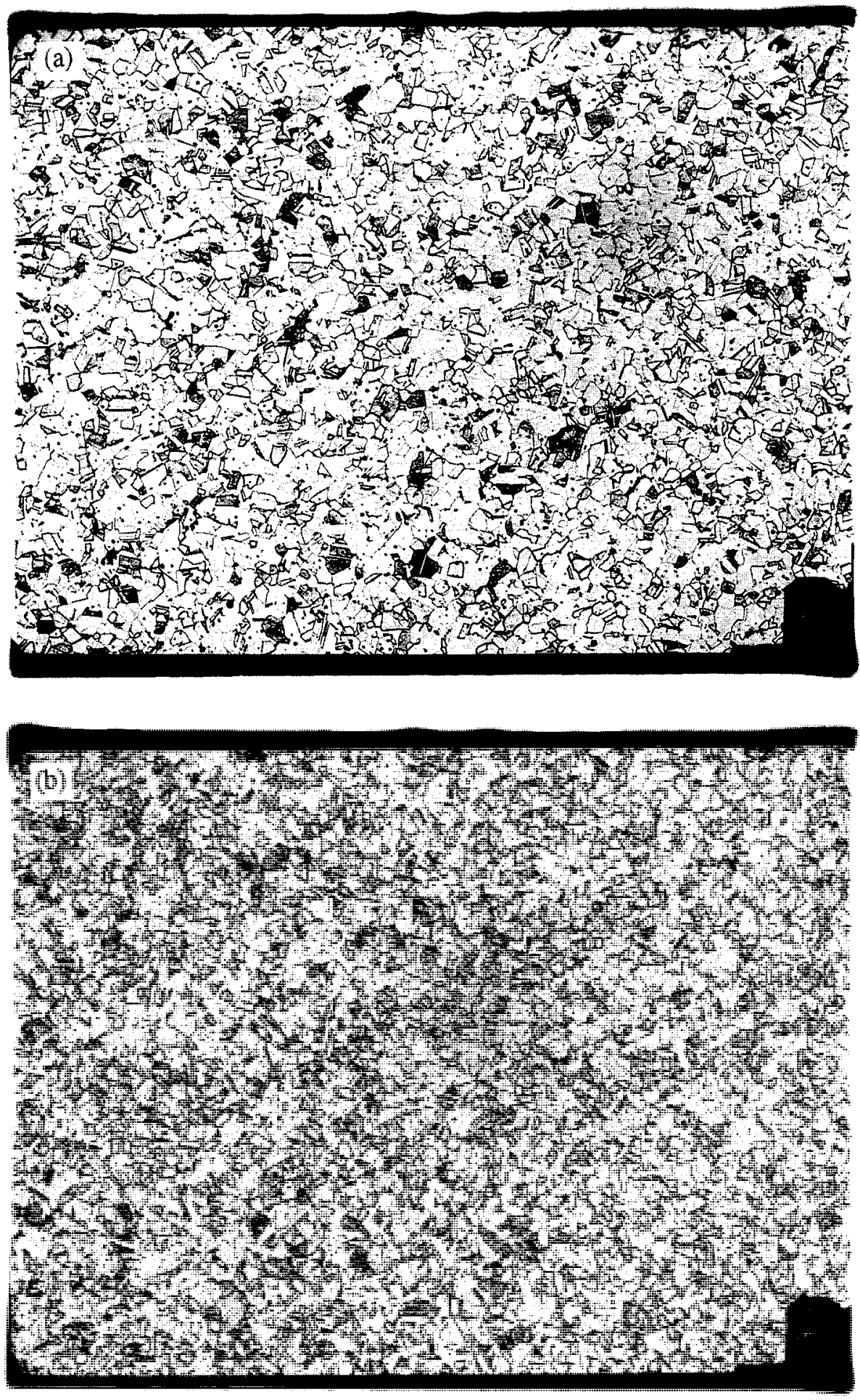

Figure 4.16. Microstructure of Type P Stainless Steel Vessels. Magnification $=100$. Grain Size $-9 \mu \mathrm{m}$. (a) New Type Vessel. (b) Used Type P Vessel. 

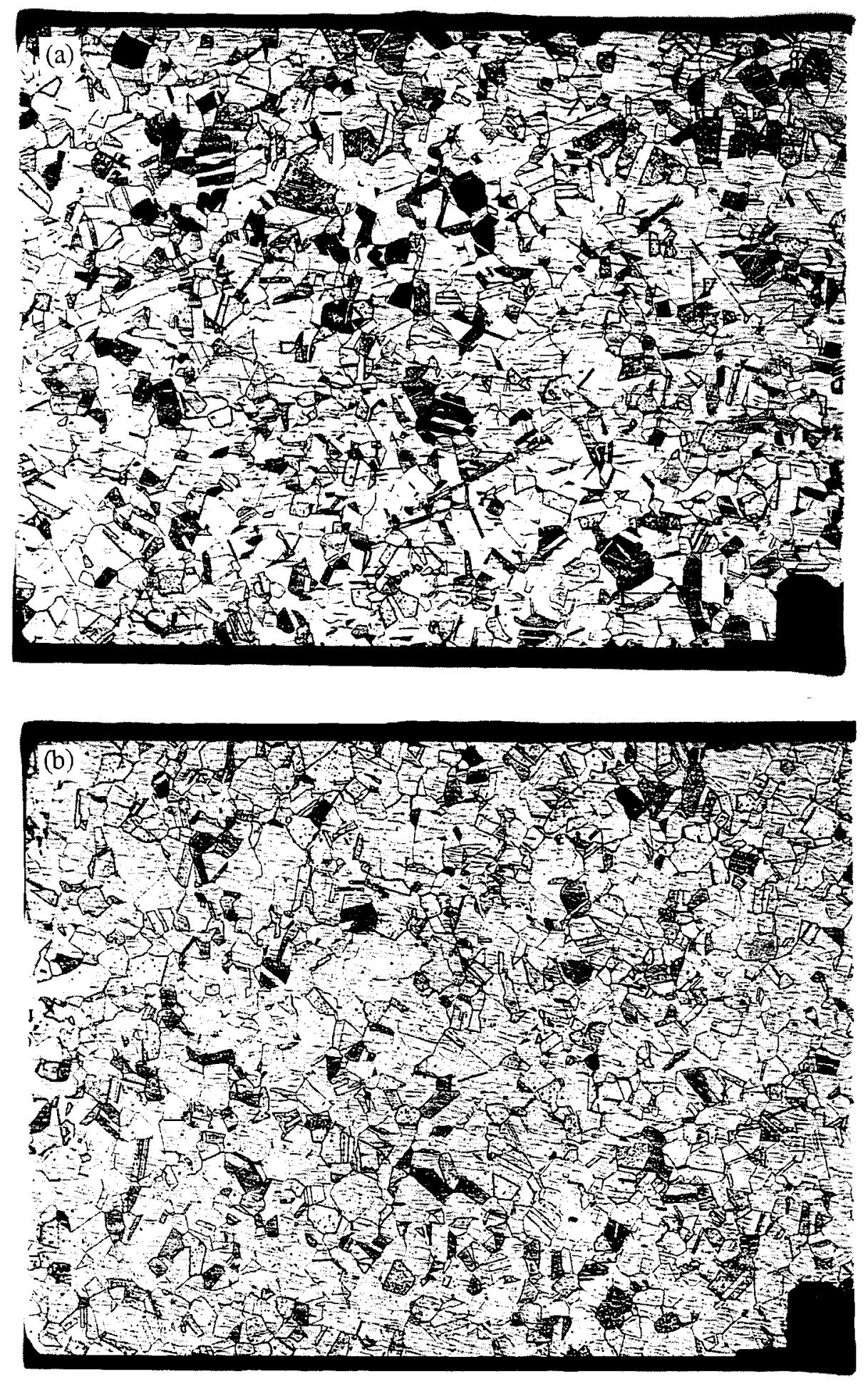

Figure 4.17. Microstructure of Type W Stainless Steel Vessels. Magnification $=100$. Grain Size $=16 \mu \mathrm{m}$. (a) New Type W Vessel. (b) Used Type W Vessel. 

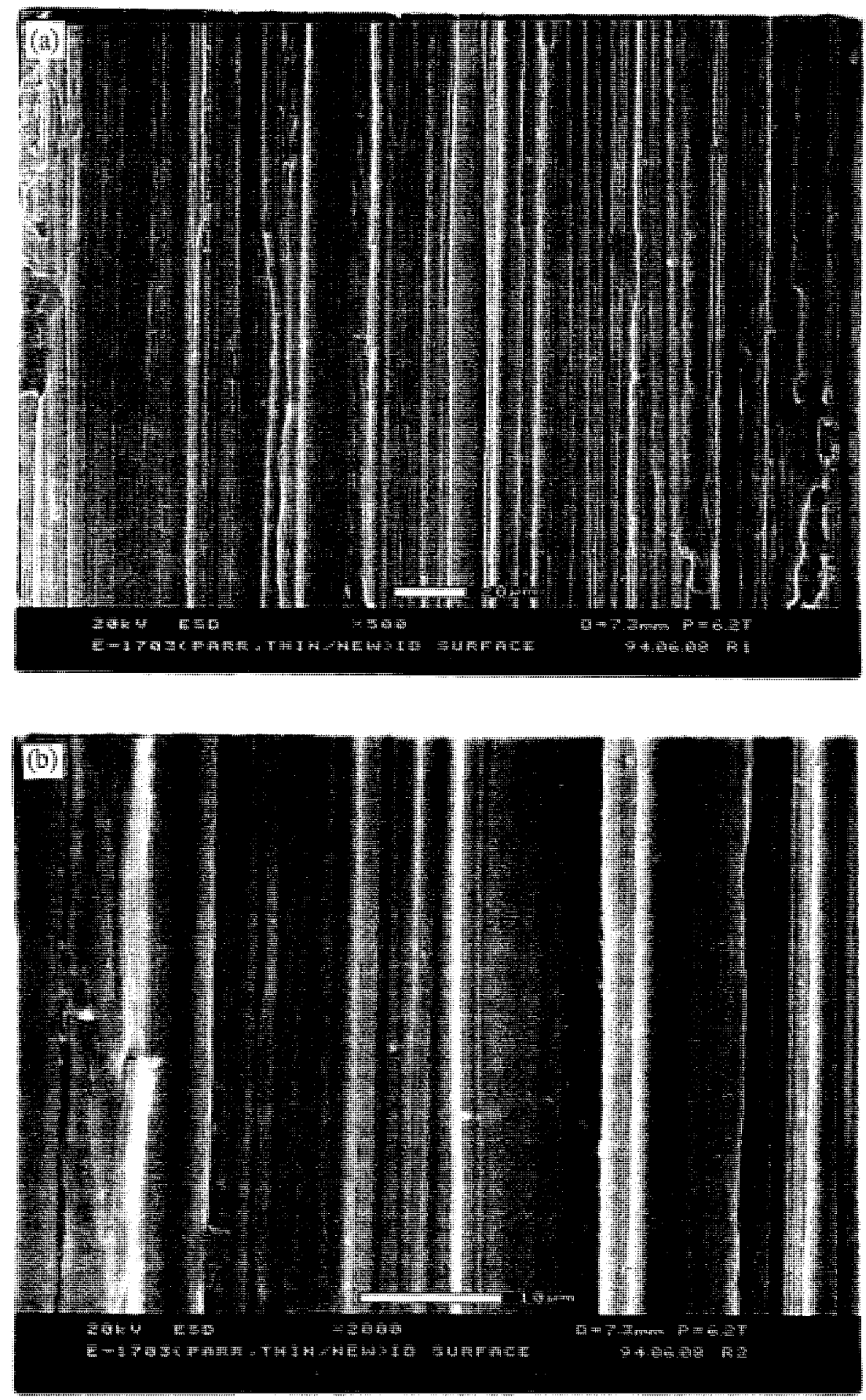

Figure 4.18. Scanning Electron Microscope Examination of New Type P Vessels. (a) Magnification $=500$. (b) Magnification $=2000$. (c) Magnification $=5000$. 


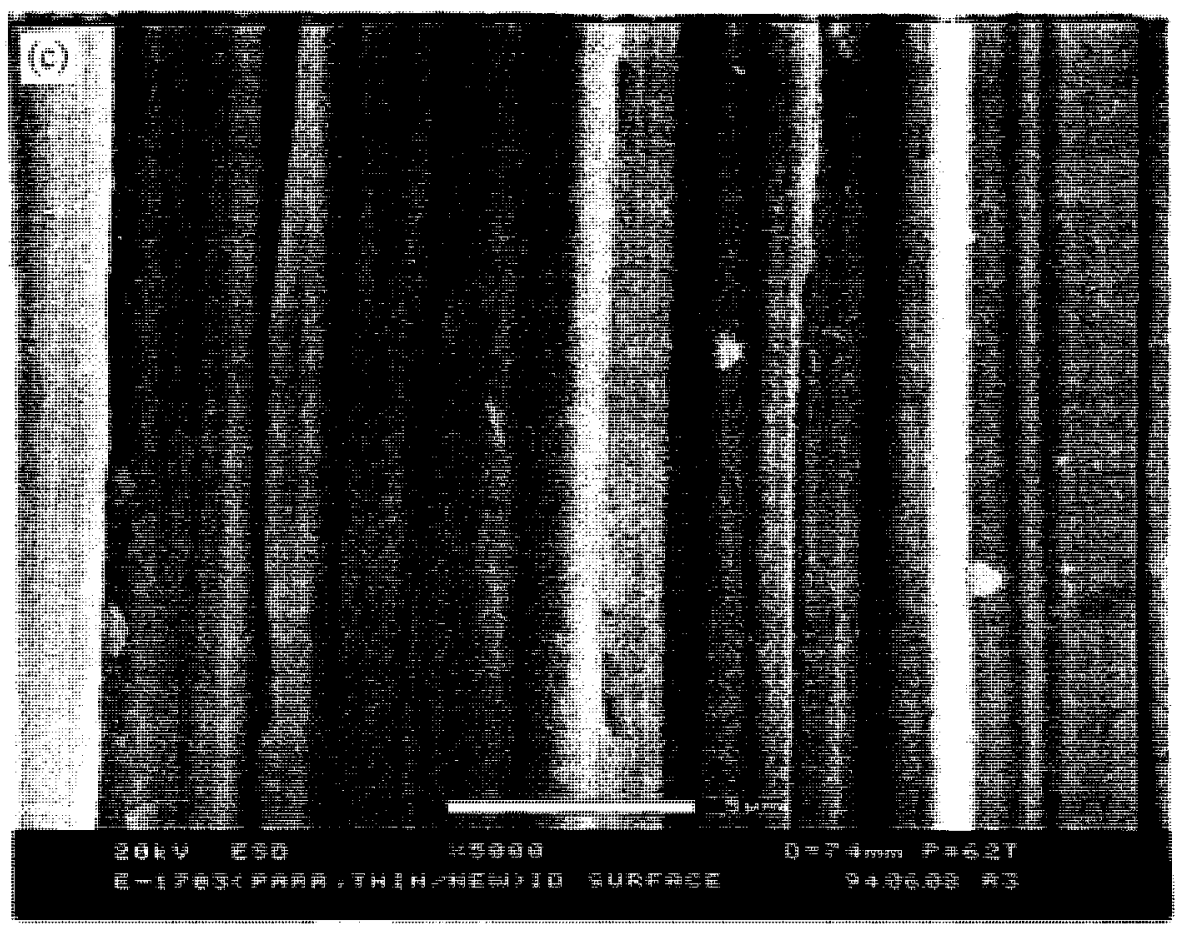

Figure 4.18. (contd) 

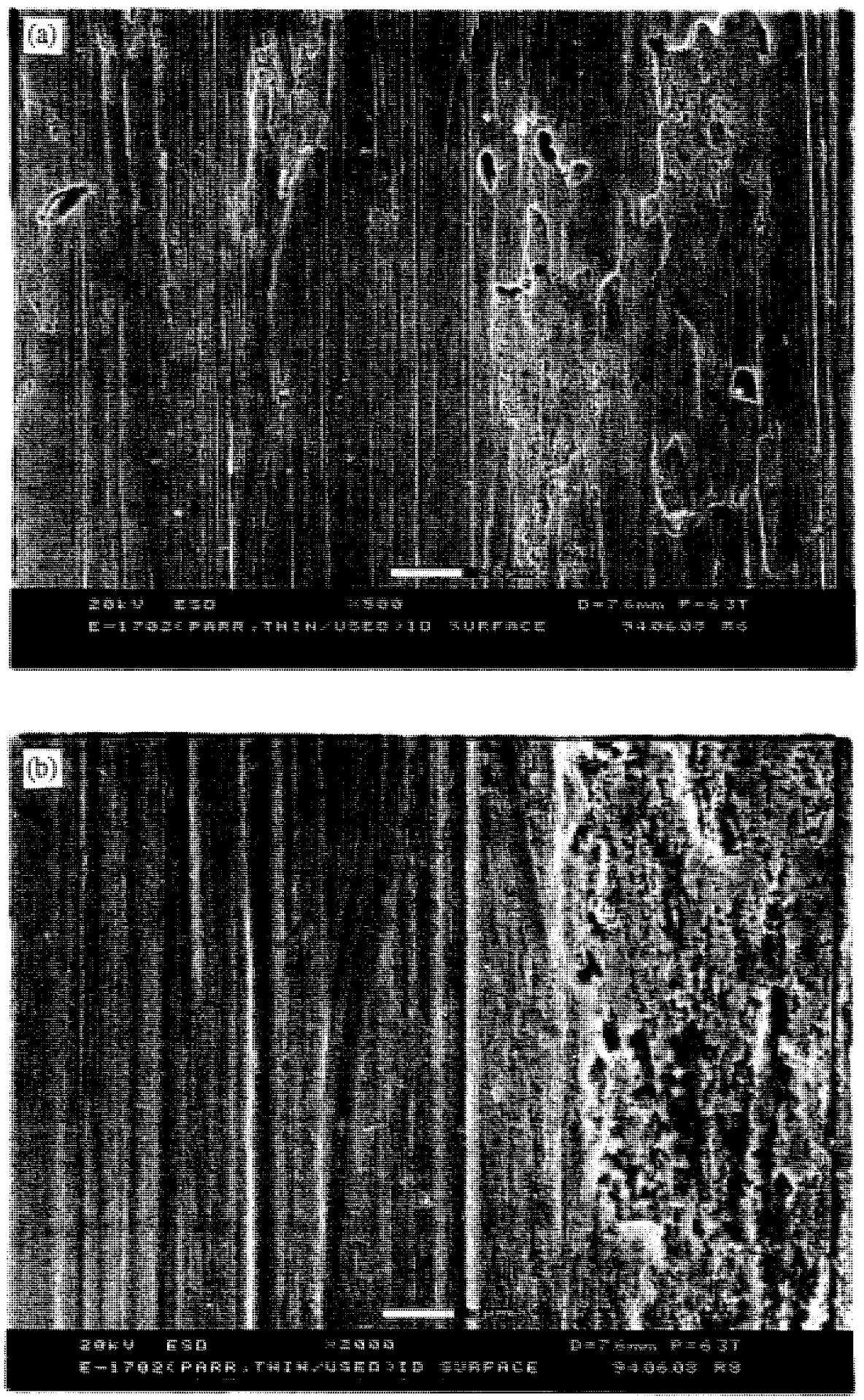

Figure 4.19. Scanning Electron Microscope Examination of Used Type P Vessels. (a) Magnification $=500$. (b) Magnification $=2000$. (c) Magnification $=5000$. 


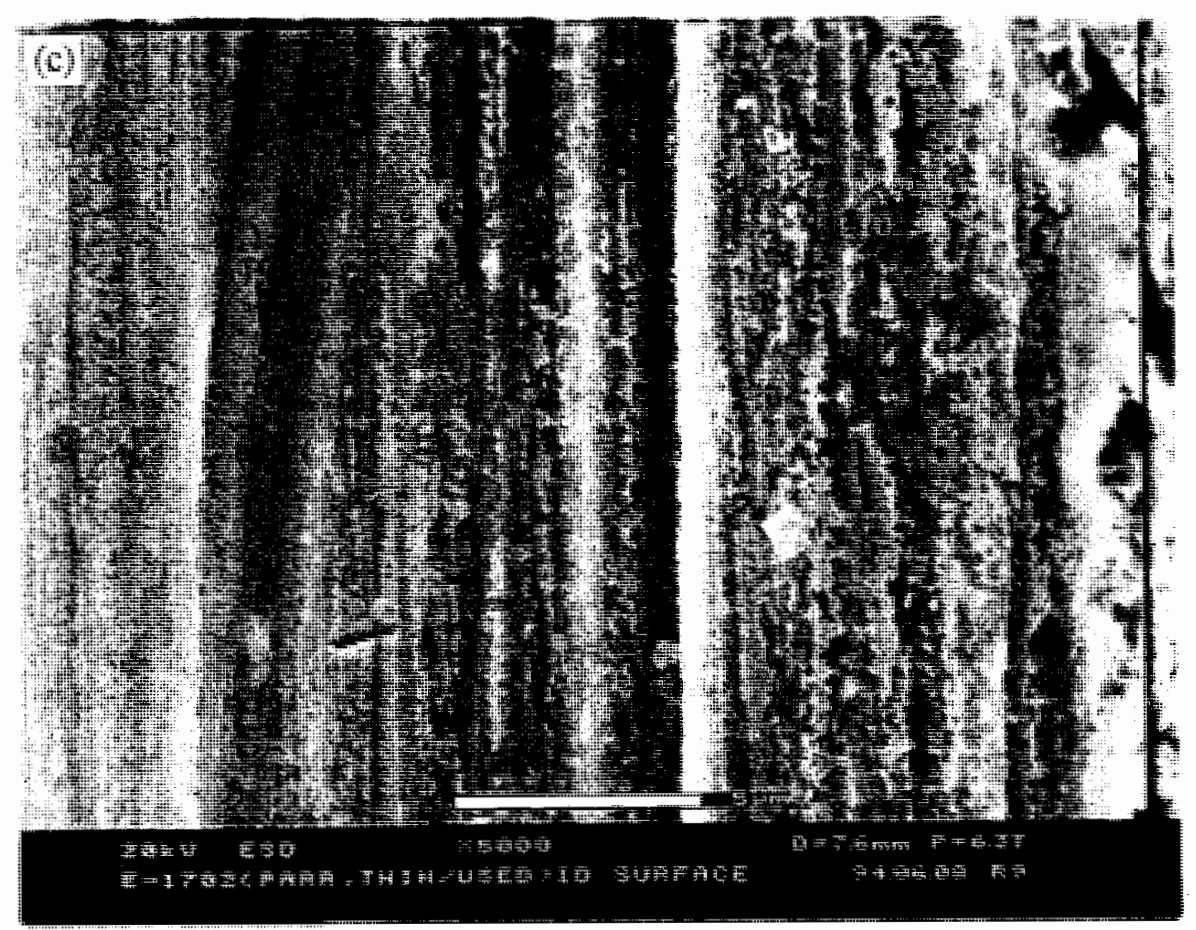

Figure 4.19. (contd) 

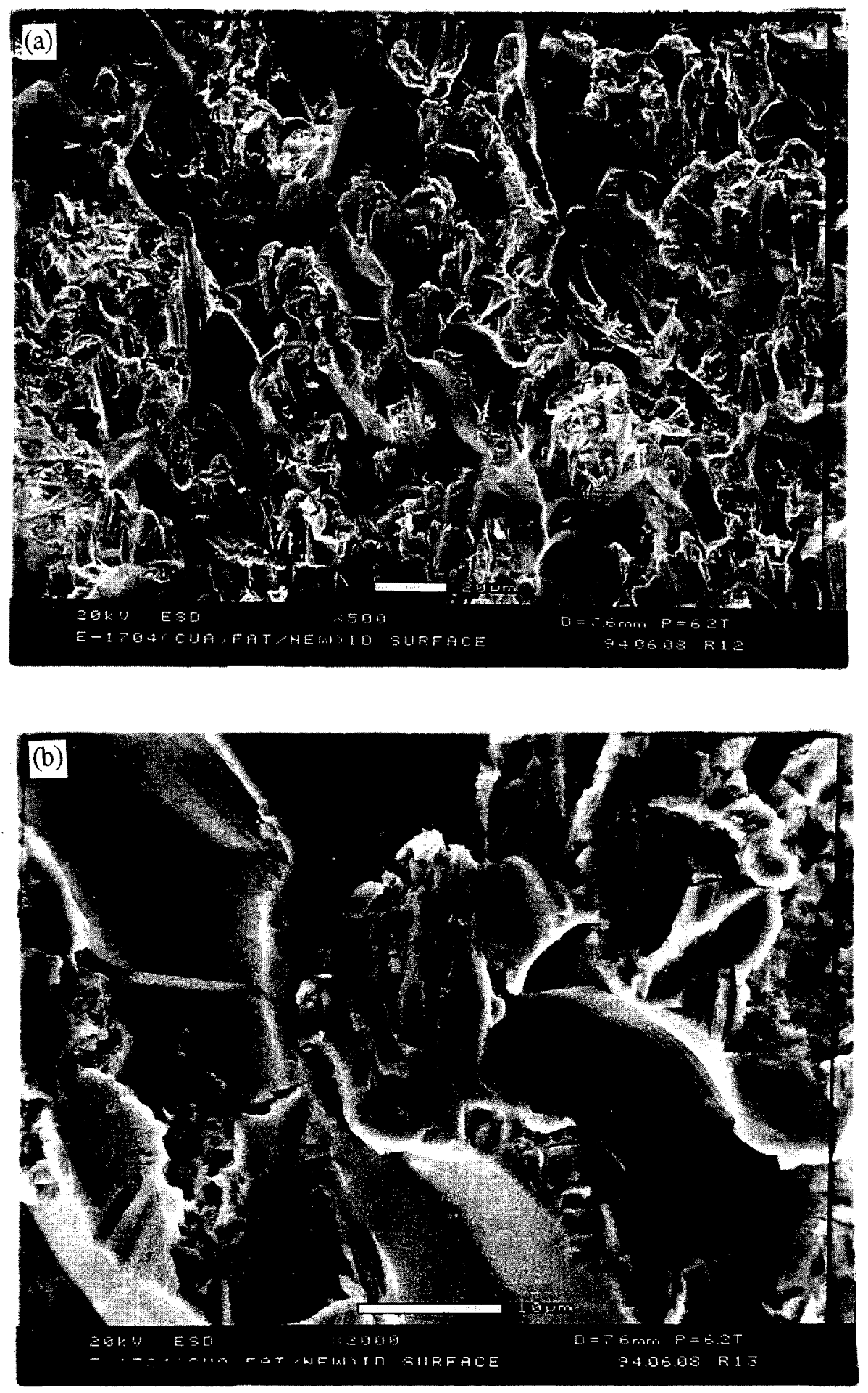

Figure 4.20. Scanning Electron Microscope Examination of New Type W Vessels. (a) Magnification $=500$. (b) Magnification $=2000$. (c) Magnification $=5000$. 


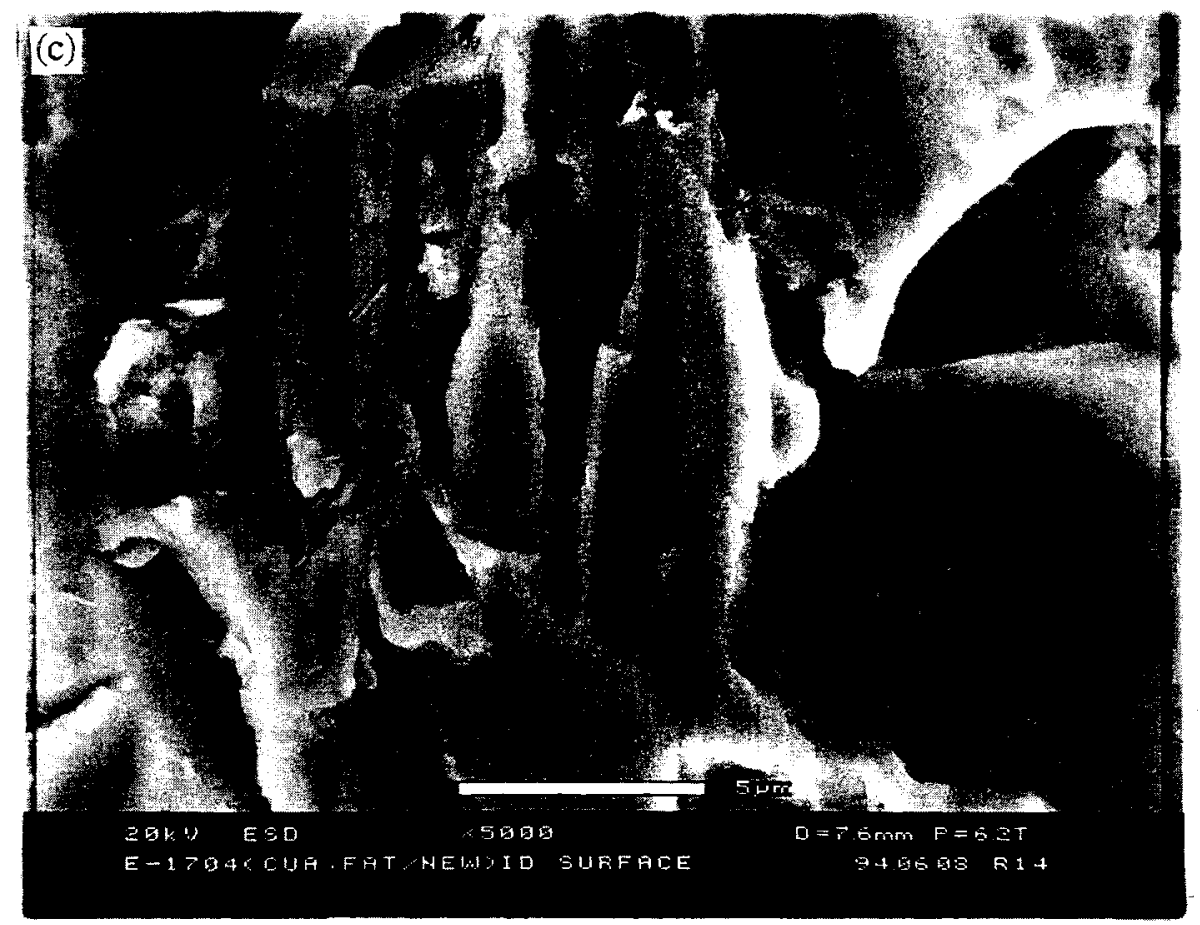

Figure 4.20. (contd) 

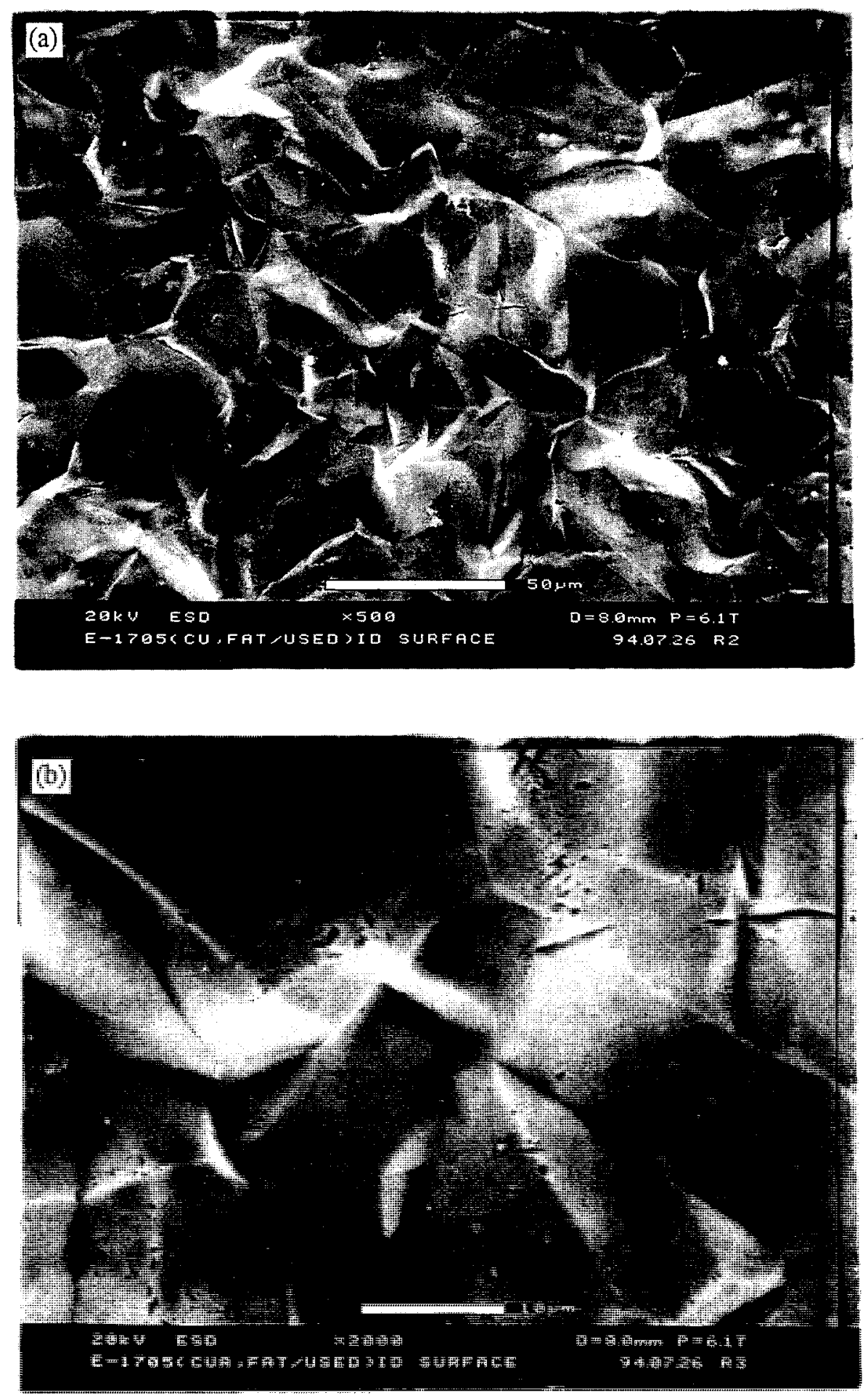

Figure 4.21. Scanning Electron Microscope Examination of Used Type W Vessels. (a) Magnification $=500$. (b) Magnification $=2000$. (c) Magnification $=5000$. 


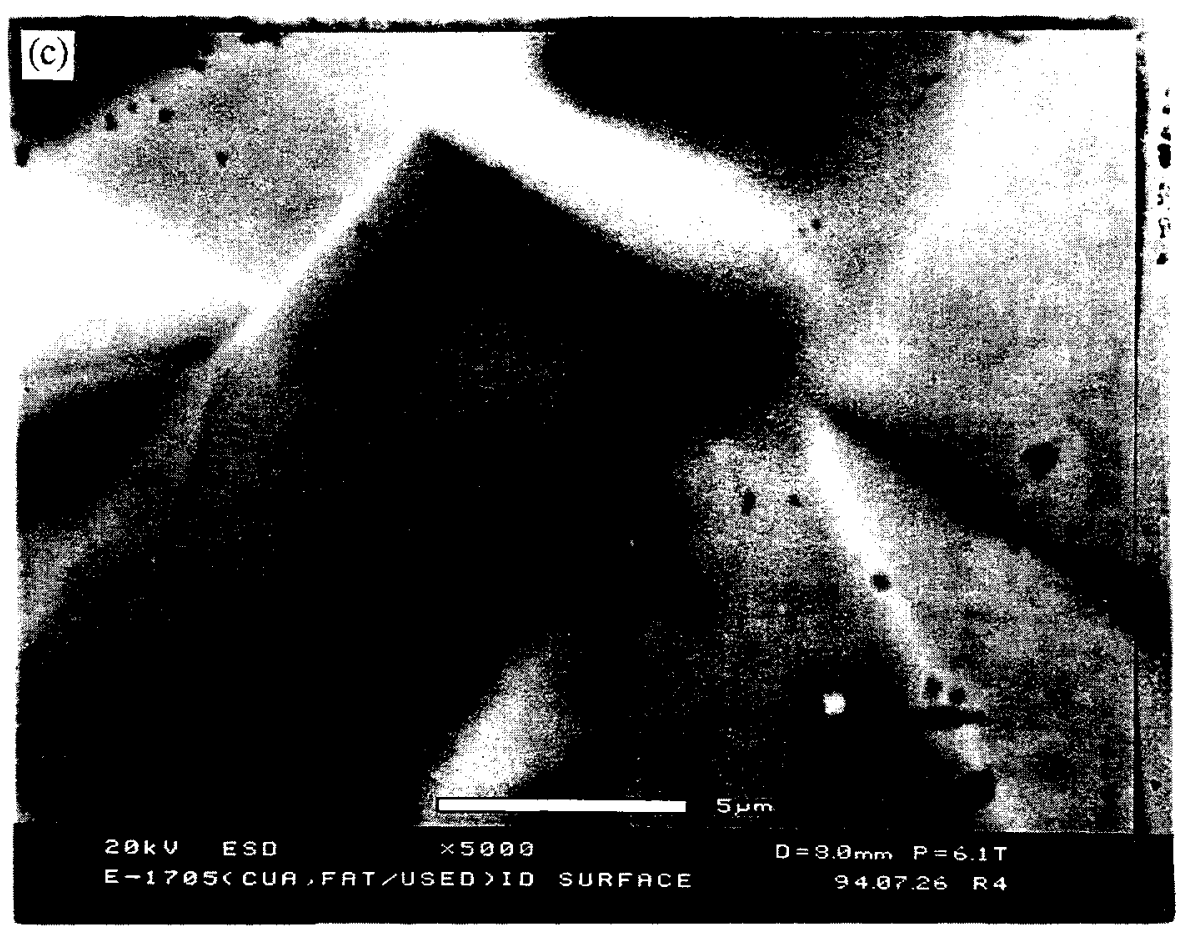

Figure 4.21. (contd) 
The surface damage to the inside surfaces of the two types of vessels (Figures 4.18 and 4.21) is only revealed under high magnification and is minor in nature; no intergranular corrosion was

revealed. The damage probably occurred during cleaning in hot nitric acid solution. However, since the leachates in the type $\mathrm{W}$ vessels showed higher initial levels of Fe, some interaction between the leachate and the rough wall apparently occurred. 


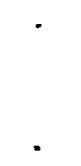




\subsection{Conclusions and Recommendations}

Defense Waste Processing Facility EA Glass and WVNS reference glasses 5 and 6 were tested using the PCT. The tests were conducted in vessels made of 304L stainless steel and PFA resin. The test results, including $\mathrm{pH}$ values and elemental releases of $\mathrm{B}, \mathrm{Li}, \mathrm{Na}$, and $\mathrm{Si}$, were compared. No significant differences were found, and the permeability of the PFA vessels to atmospheric $\mathrm{CO}_{2}$ did not affect the results in this study. Although experimental error was highest with the type $W$ vessels, operator inexperience using the vessel was probably the biggest contributor. Head space was varied only in the type W containers, and only on 1 sample of each glass; no differences in leaching results were found. The microstructures of type $P$ and type $W$ stainless steel vessels appeared similar. The average grain size of new and used type P vessels was approximately $9 \mu \mathrm{m}$, and the grain size of new and used type $W$ vessels was approximately $16 \mu \mathrm{m}$. This difference in grain size had no apparent effect on leaching results.

Visually, the interior of type W vessels was much rougher than the interior of type $\mathrm{P}$ vessels. However, SEM examination revealed machining marks on the inside of the type P vessels as well as roughness on the inside of the type W vessels. After four cycles of use (including acid cleaning), both types showed surface damage consisting of pitting and etching or corrosion. But in spite of the damage, the roughness generally did not affect leaching test results. However, one small difference was found in durability testing using the type $W$ vessels that may be due to the rough inner surface of type $\mathrm{W}$ vessels. Iron appeared in the leachates during the first durability test in each new type W vessel. The presence of Fe decreased with subsequent uses and apparently does not affect $\mathrm{pH}$ values or any other elemental leachate levels.

On the basis of these studies, results from PCTs performed in either 304L stainless steel or PFA test vessels showed no difference owing to the test vessel material. However, only the three glasses were tested for this experimental work; additional glass compositions should be studied to determine the effect of test vessel material on leaching behavior. In particular, the same PUREX glass tested by Xing and Pegg (1994) should be tested by an independent laboratory to determine if their results can be duplicated. 

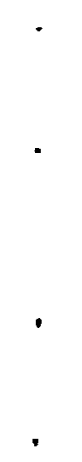


\subsection{References}

40 CFR Part 148 22700. June 1, 1990. "Land Disposal Restrictions for Third Scheduled Wastes; Rule." Federal Register, pp. 22519-721.

ASTM E112-84. "Standard Methods for Determining Average Grain Size," Annual Book of ASTM Standards, Section 3, Vol. 03.03. American Society for Testing and Materials, Philadelphia.

Jantzen, C. M., N. E. Bibler, D. C. Beam, C. L. Crawford, and M. A. Pickett. 1993. Characterization of the Defense Waste Processing Facility (DWPF) Environmental Assessment (EA) Glass Standard Reference Material (U). WSRC-TR-92-346, Rev. 1, Westinghouse Savannah River Company, Aiken, South Carolina.

Jantzen, C. M., N. E. Bibler, D. C. Beam, C. L. Crawford, and M. A. Pickett. 1994. "Development and Characterization of the Defense Waste Processing Facility (DWPF) Environmental Assessment (EA) Glass Standard Reference Material (U)," Ceramic Transactions Vol. 39, Environmental and Waste Management Issues in the Ceramic Industry, ed. G. B. Mellinger. The American Ceramic Society, Westerville, Ohio.

Jantzen, C. M., N. E. Bibler, D. C. Beam, W. G. Ramsey, and B. J. Waters. 1992. Nuclear Waste Glass Product Consistency Test (PCT) - Version 5.0 (U). WSRC-TR-90-539, Rev. 2, Westinghouse Savannah River Company, Aiken, South Carolina.

Olson, K. M., S. C. Marschman, G. F. Piepel, and G. K. Whiting. 1994. Product Consistency Testing of West Valley Compositional Variation Glasses. PNL-10191, Pacific Northwest Laboratory, Richland, Washington.

Reimus, M.A.H., G. B. Mellinger, G. F. Piepel, and L. R. Bunnell. 1988. West Valley Glass Product Qualification Durability Studies, FY 1987-1988: Effects of Composition, Redox State, Thermal History, and Groundwater. PNL-6723, Pacific Northwest Laboratory, Richland, Washington.

U.S. Department of Energy (DOE). 1981. The Evaluation and Review of Alternative Waste Forms for Immobilization of High-Level Radioactive Wastes. Report No. 3, Alternative Waste Form Peer Review Panel Report, DOE/TIC-11472, Washington, D.C.

U.S. Department of Energy (DOE). 1993. Waste Acceptance Product Specifications for Vitrified High-Level Waste Forms. DOE-DWPD-FY93-0288, Office of Environmental Restoration and Waste Management, Washington, D.C.

U.S. Department of Energy (DOE). 1994. High-Level Waste Borosilicate Glass: A Compendium of Corrosion Characteristics. Vol. 1-3, ed. J. C. Cunnane, DOE-EM-0177, Office of Waste Management, Washington, D.C. 
Westinghouse Savannah River Company (WSRC). 1988. Wasteform Compliance Plan for the Defense Waste Processing Facility. WSRC SW 4-6, Rev. 0, Westinghouse Savannah River Company, Aiken, South Carolina.

Xing, S., and I.L. Pegg. 1994. "Effects of Container Material on PCT Leach Test Results for HighLevel Nuclear Waste Glasses." Scientific Basis for Nuclear Waste Management XVII, eds. A. Barkatt and R.A. Van Konynenburg. Materials Research Society, Pittsburgh, Pennsylvania. 


\section{Distribution}

No. of

Copies

\section{Offsite}

12 DOE/Office of Scientific and Technical Information

J.K. Bates

Argonne National Laboratory

Chemical Technology Division

9700 South Cass Avenue

Argonne, IL 60439-4837

D.C. Beam

Westinghouse Savannah River Company

P.O. Box 616

Aiken, SC 29808

N.E. Bibler

Westinghouse Savannah River Company

P.O. Box- 616

Aiken, SC 29802

A. Drobot

West Valley Nuclear Services

Company, Inc.

P.O. Box 191

West Valley, NY 14171-0191

V. Jain

West Valley Nuclear Services

Company, Inc.

P.O. Box 191

West Valley, NY 14171-0191

C.M. Jantzen, 773A

Westinghouse Savannah River Company

P.O. Box 616

Aiken, SC 29801
No. of

Copies

K.M. Olson

131 Casa Sueno Ct.

Richland, WA 99352

R.A. Palmer

West Valley Nuclear Services Company, Inc.

P.O. Box 191

West Valley, NY 14171-0191

I.L. Pegg

Catholic University of America

Vitreous State Laboratory

620 Michigan Avenue

Washington, DC 20064

M.J. Plodinec

Westinghouse Savannah River Company

P.O. Box 616, MS 773-A

Aiken, SC 29802

\section{Onsite}

2 DOE Richland Operations Office

S.T. Burnum, S7-53

22 Pacific Northwest Laboratory

L. Ballou, P7-18

J.W. Johnston, K5-12

S.C. Marschman, P7-18

B.P. McGrail, K2-38

G.F. Pipel, K5-12

M.J. Schweiger, P8-37

G.L. Smith (10), P7-14

Publishing Coordination

Technical Report Files (5) 


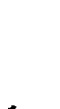

